\title{
COLUMBIA RIVER BASIN \\ FISH AND WILDLIFE PROGRAM \\ ANNUAL IMPLEMENTATION WORK PLAN \\ FOR FISCAL YEAR 1992
}

\author{
BY \\ DIVISION OF FISH AND WILDLIFE \\ BONNEVILLE POWER ADMINISTRATION \\ P.O. BOX 3621 \\ PORTLAND, OREGON 97208
}

September 1991 
The Columbia River Basin Fish and Wildlife Program Annual I mplementation Work PIan (AIWP) for Fiscal Year (FY) 1992 presents Bonneville Power Administration's (BPA) plans for implementing the Columbia River Basin Fish and Wildlife Program (Program) in FY 19g2. The Al WP focuses on individual Action Items found in the 1987 Program for which BPA has determined that it has authority and responsibility to implement. Each of the entries in the Al WP includes objectives, background, progress to date in achieving the objectives, and a summary of plans for implementation in Fy 1992. Most Action Items are implemented through one or more BPA-funded projects. Each Action I tem entry is followed by a list of completed, ongoing, and planned projects, along with objectives, results, schedules, and milestones for each project.

In October 1988, BPA and the Columbia Basin Fish and Wildlife Authority (CBFWA) initiated a collaborative and cooperative I mplementation PIanning Process (IPP). The IPP provided opportunities in FY 1991 for the fish and wildlife agencies, Tribes, and other interested parties to be involved in planning FY 1992 Program implementation. This planning process contributed to the development of this year's AIWP. The joint BPA/CBFWA IPP is expected to continue in Fy 1992.

The FY 1992 Al WP emphasizes continuation of 143 ongoing, or projected ongoing, Program projects, tasks, or task orders, most of which involve protection, mi tigation, or enhancement of anadromous fishery resources. The FY 1992 Al WP also contains 10 new Program projects or tasks that are planned to start in Fy 1992.

The continuing and new activities in FY 1992 are summarized briefly by Program or technical area:

Mainstem Passage: BPA.funded projects will continue to support the smolt marking and monitoring program, the Fish Passage Center, and management of the Water Budget (pp. 39.47). BPA will continue to implement 10 projects in the Reservoir Mortality and Water Budget Effectiveness Research Area of Emphasis (pp. 139-146), as agreed upon through ad hoc negotiation with the fishery agencies and Tribes. A new bypass evaluation project (p. 263) is expected to start in Fy 1992.

Artificial Propagation: The aim of this Program area is primarily to investigate ways to increase the quality and quantity of fish produced in hatcheries. In FY 19g2, BPA plans to continue i mplementing 15 ongoing Hatchery Effectiveness and Fish Disease Technical Work Group (TWG) Five-Year Work PIan research projects (pp. 147-158). To i mplement a Policy Review Group recommendation to reduce hatchery effectiveness and fish disease research, BPA will defer four fish disease research projects in FY 1992 (see PIans for Action Item 6.2 on pp. 137-138).

Natural Propagation: A total of 31 ongoing habitat and tributary passage projects in Section $703(\mathrm{c})(1)$ of the Program will continue or be completed 
in Fy 1992 (pp, 55-78). These projects, located throughout Oregon, Idaho, and Washington, emphasize enhancement of anadromous fish spawning and rearing habitat and improvement of passage conditions, with the goal of increasing production of naturally spawning stocks.

Supplementation: Six ongoing supplementation research projects from the Supplementation TWG Five-Year Work PIan will continue in Fy 1992 (pp. 159-162). The goal of supplementation research is to improve programs for supplementing natural production areas with stocked fish, whether from hatchery or wild stocks, and to assess the potential of supplementation to increase natural production.

Resident Fish: The resident fish projects begun in Fy 1991 or before (pp, 179.215) will continue, as will the sturgeon studies being carried out throughout the Basin ( $p$. 202). A new habitat enhancement project on the Fort Hall Reservation will be added to the resident fish program during FY 1992 ( $p .197$ ). The FY 1991 "placeholder" project for Hungry Horse and Libby Dam mitigation (p. 267) is expected to provide funding for one or more new mitigation projects in Fy 1992, once the council has amended the Program.

Wildlife: In Fy 1992, the shift in emphasis from planning to actual mitigation projects will continue. BPA will continue to implement the six ongoing wildlife mitigation projects under Action Item 8.12

(pp. 238-240). A "placeholder" project for Fy 1992 wildlife mitigation in Oregon, Washington, and I daho has been included in the AIWP (p. 240).

Once individual new FY 1992 projects are developed through the IPP, the Al WP will be amended to include the projects. A new project to develop a wi I dlife monitoring and evaluation program (p. 242) is planned to start in FY 1992 .

Major Projects: This category includes major hatchery construction, passage i mprovement, and habitat enhancement projects implemented by BPA's Fish and Wildlife Project Management Branch. During FY 1992, the following activities will continue: final design of the Yakima/klickitat Production Facilities ( $p$. 100), development of the Master Plan for the artificial production facility or facilities to be located in northeastern Oregon ( $p .108$ ), prelimi nary design of the Nez Perce Low-Capital Propagation Facilities ( $p$. 118), and operation and maintenance of the Colville Hatchery ( $p .180$ ), Umatilla Hatchery (p. 113), Sherman Creek Hatchery (p. 184), and Spokane Tribal Hatchery (p. 185). New FY 1992 projects include design and construction of Dryden Dam screens ( $p .85$ ) and five tasks associated wi th the Yakima/Klickitat Production Project $(p p, 103-105)$.

PIanning Activities: The IPP will continue to guide BPA's Program implementation in FY 1992 (pp, 23-24), and BPA will continue to participate in the seven IPP Scoping Groups. BPA will also participate in 
the Council-managed System and Subbasin PIanning and System Monitoring and Evaluation programs (pp, 29-30).

Non-Program. Internal Support Projects: BPA's Division of Fish and Wildife will also conduct a number of activities not included in the Council's Program. Several activities, such as BPA's contract with Resources for the Future, are funded by BPA to analyze and improve our understanding of basic fish and wildlife issues. Some of the other non-Program activities funded by BPA are the coordination of the IPP, technical assistance to the Division of Fish and Wildlife, and Idaho water rental projects. To help the public better understand what BPA is doing, Appendix $A$ ( $p$. A-1) describes the non-Program, internal support projects currently funded by BPA.

Endangered Species Act I mplementation: BPA's activities are likely to increase during FY 1992, particularly as a result of petitions to list five species of Columbia and Snake River salmon under the Federal Endangered Species Act (ESA). BPA will use, to the extent practicable, the IPP to plan implementation of ESA and Council Early Implementation Package (EIP) projects. In all cases, BPA will keep the Policy Review Group informed regarding all of the ESA and EIP activities we are pursuing. Appendix B (p. A- 13) describes the ESA projects that BPA is currently i mplementing.

Early I mplementation Package: An addendum, outlining BPA's plans for i mplementing the EIP actions recently amended into the Program, has been included at the end of the AI WP. 
Page

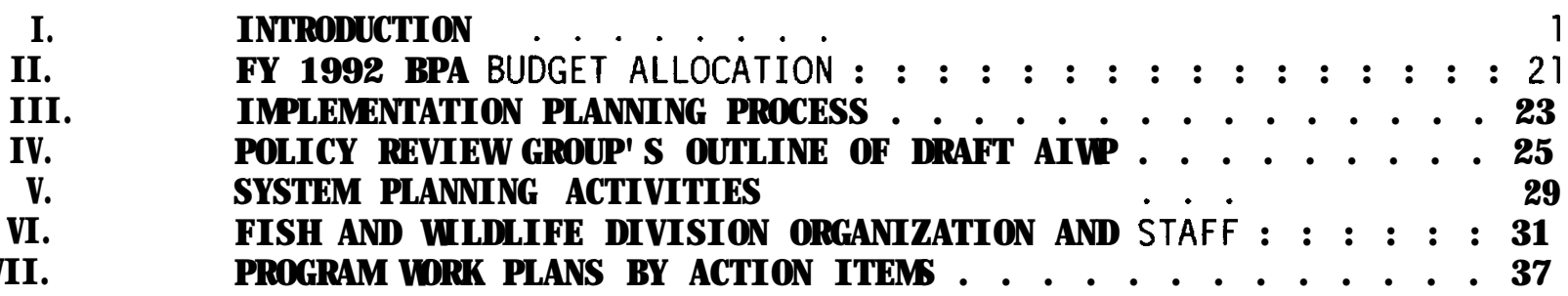

ANADROMOUS FISH ACTION ITEMS AND TECHNICAL SUBJECTS

1987

Program

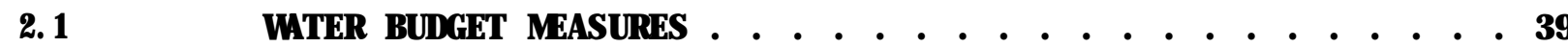

2.2 SMOLT MONITORI NG PROGRAM , , , , , , , , , , , , , , 43

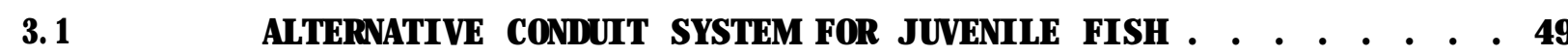

( Test and Evaluate: November 15, 1987; Report

January 1988)

4.1 ELLENSBURG TOWN DI VERSI ON DAM FISHWAY AND

B Y P A S S , , , , , , , , , , , , 51

(Design: October 1987)

(Construction Completed: October 1988)

(Consider Delay if Consolidation Suggests

Benefits >

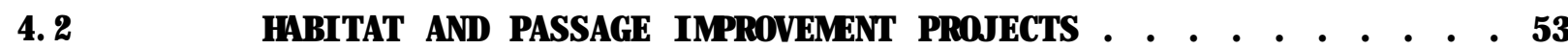
( Consult with Project Sponsors on

Need; Complete by 1991)

4.3 ROZA DAM FISH PASSAGE FACILITIES

(Juvenile Facilities Completion: March 1, 1987).

(Adult Facilities Completion: March 1, 1988)

4.4 PROSSER DAM FISH PASSAGE FACILITIES，，，，，，，，81

(J uvenile Facilities Completion: March 1, 1987)

(Adult Facilities Completion: December 1, 1987)

4,5 YAKI MA RI VER FISH PASSAGE I MPROVEMENTS , , , , , , , , , 83

( Completion of Elements in Table 3 of

904(d)(4): December 1, 1988)

(Post-Construction Evaluations)

4.6 WATER EXChANGE FOR UMATILLA RIVER，，，，，，，，，，87

(Support Beginning Spring 1987)

(Report Evaluations: Annually) 
$4,6,1$

EVALUATE NON-Structural WATER MEASURES IN UMATILla ， ， ， ， 1 BASI N

(Develop Work plan; Report to Council in April 1989)

$4,14,1$

TEMPORARY J OHN DAY ACCLIMATI ON FACILITY , , , , , , , , , , 93

(Upon Council Approval, Complete Construction

by Spring 1988)

4.15.1 DESIGN AND CONSTRUCTI ON OF YAKI MA HATCHERY ，，，，，， 95 (Upon Council Approval, Fund Beginning in FY 1988)

4.16.1- NORTHEASTERN OREGON SPRING CHINOOK

(Upon Council Approval, Fund Design and

Construction)

4.17.1 JUVENILE RELEASE/ADULT COLLECTION AND HOLDING

FACI LITIES ON UMATILLA RESERVATI ON , , , , , , , , , 109

(Operate, Maintain>

4.17.2 EXPANDED UMATILla hatchery，，，，，，，，，，，，１11 (Fund upon Council Approval)

4.17.3 LOW-CAPITAL PRODUCTION FACILITY ON NEZ PERCE RESERVATI ON ................................... 117

(Design/Begin Construction by May 1989))

4.17.4 HABITAT SURVEY ASSOCIATED WI TH ACTION I TEM 4,17, 3 (Fund) , , , , , , , , , , , , , , 119

Del eted I MPROVED HATCHERY EFFECTI VENESS ，，，，，，，，，，，121

4.17,5 WI LLAMETTE BASIN STUdY PLAN , , , , , , , , , , , 125

(Fund; Coordinate with Supplementation Work PI an)

4.17.6 PROPAGATI ON OF SALMON/STEELHEAD I N PELTON DAM

FISH LADDER .. . . . . . . . . . . . . . . . . . 127

(Fund upon Council Approval of Master Plan)

4.21 HATCHERY RELEASES IN UPPER COLUMBIA，，，，，，，， 129

(Upon Council Review of Reprogramming PIan,

Fund Releases $>$

5.1 KNOWN STOCK FISHERIES FIVE-YEAR DEMONSTRATION

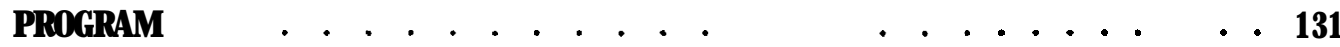

(Co-Fund to Test Electrophoresis: Begin 1985

ocean Fishing Season or Subsequent Seasons) 
6.1 TECHNI CAL WORK GROUPS, , , , , , , , , , , , 133

(Begin to Fund in FY 1987)

6.2 RESEARCH I N THE FI VE-YEAR WORK PLANS ， ， , , , , , , , 137

(Begin to Fund in FY 1988)

6.3 DATA COLLECTI ON FOR HATCHERY DATA BASE，，，，，，，，163

(Fund in Response to system Monitoring

and Evaluation Work Group Proposalsl

6.4 DATA COLLECTION FOR NATURAL PRODUCTION

DATABASE , , , , , , , , , , , , , , , , 165

(Fund in Response to system Monitoring

and Evaluation Work Group Proposals $>$

6,5 HIGH PRIORITY PROJECTS IN AREAS OF EMPHASIS ， ， , , , , 167

(Fund Only These in Fy 1987)

6.10 SYSTEM MONI TORING AND EVALUATION ， ， ，，，，， . . . 169

(Coordinated Information System)

COORDI NATI ON ACTI ON I TEMS

6.12 CONTINUING COORDINATION AND CONSULTATION

(By All Federal Project Operators/Regulators;

RESI DENT FISH ACTION I TEMS AND TECHNICAL SUBJECTS

1.1 COLVILle hatchery，，，，，，，，，，，，，179

(Complete Construction: March 1989)

(Fund Operation and Maintenance)

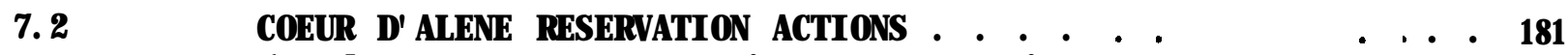

(Fund Stream Survey; Design, Construction, Operation, and Maintenance of Cutthroat /

Bull Trout Hatchery; Habitat I mprovement

Projects; 3-Year Monitoring Program>

7. 3 KOKANE SALMON HATChERIES , . . . . . . . . . . . . . . 183

(Fund Design, Construction, Operation,

Maintenance of Hatcheries at Galbraith

Springs and Sherman Creek: Begin Fy 1988)

(Fund Monitoring Programs)

7. 4 HABITAT AND PASSAGE I MPROVEMENTS ON LAKE

ROOSEVELT TRI BUTARY STREAMS , , , , , ， . . . . . . . . 187

(Fund Design, Construction, Operation,

Maintenance of Projects: Begin FY 1989)

(Fund Monitoring Programs > 
7,5

KOOTENAI I NDI AN RESERVATI ON STURGEON HATCHERY ，，，，，，189

(Fund Design, Construction, Operation,

Maintenance of Hatchery: Begin FY 1988)

(Fund Evaluation Study)

7.6 STURGEON AND WATER LEVEL FLUCTUATIONS: I DAHO

PORTI ON OF KOOTENAI RI VER , , , , , , , , , , , , 191

(Fund Study to Assess I mpacts: Begin Fy 1989)

7. 7 PEND OREI LLE RI VER FISHERY I MPROVEMENTS ON

KALI SPEL RESERVATI ON , , , , , , , , , , , , , , , 193

(After Council Consultation, Fund Assessment

of Improvement Opportunities: Begin FY 1988)

7.10 FUND PROJECTS AS PROVIDED IN SECTION

903(g)(2) AND ACTION I TEM 7.8, , , , , , , , , , , 195

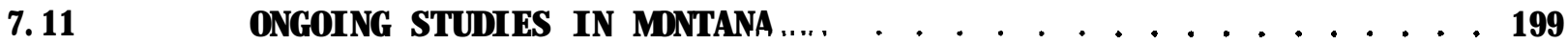

(Continue Cooperative Studies; Present

Results to Council; Submit Recommendations

by October 1, 1989)

7.12 STURGEON STUDIES . . . . . . . . . . . . . . . 201

(Fund Ongoing Studies)

Del eted PEND OREILlE HATCherY，，，，，，，，，，，，，２05

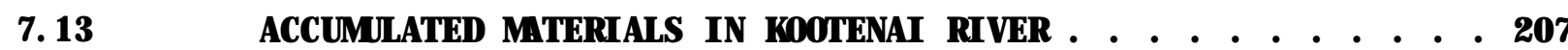
(Begi n Removal)

7.14 I MPACTS OF DWORSHAK DAM, , , , , , , , , 209

(Begin Assessment of Construction and Current Operation (mpacts)

7.15 ONGOI NG DRAWDOWN STUDIES _. . . . . . . . ...... 213

(Continue Cooperative Studies; Present Results

to Council; Submit Recommendations by

March 1, 1988)

WILDLIFE ACTION ITEMS AND TECHNICAL SUBJECTS

8.1 LoSS StatementS ， , , , , , , , , , , , , , , 219

(Fund as Needs are Identified)

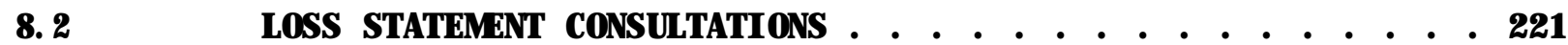
(Begin Consultation)

8.3 MI TIGATION PLANS , , , , , , , , , , , , , , , , , 225

( Fund Development) 
LI BBY DAM MITIGATI QN.,

(Begi n Advanced Design for White-Tailed Deer,

Mule Deer, Col umbia Sharp-Tailed Grouse, and

Waterfowl Projects; Continue Implementation

and Monitoring of Bighorn Sheep Project: 1987)

8,5

LI BBY DAM MI TI GATION

(Continue Advanced Design for Deer, Waterfowl, Grouse Projects; Begin I mplementation and Monitoring for Mule Deer Project; Continue I mplementation and Monitoring of Bighorn Sheep Project: 1988)

8.6

LI BBY DAM MI TIGATION , , , , , , , , , . . . 229

(Begin I mplementation and Monitoring for

White-Tailed Deer and Waterfowl Projects;

Begin Acquisition of Easements for Grouse;

Continue I mplementation and Monitoring of

Mule Deer and Bighorn Sheep Projects: 1989)

8.7

LI BBY DAM M! I I FATI ON.,

( Continue Implementation and Monitoring for White-Tailed Deer, Mule Deer, Bighorn Sheep, and Waterfowl Projects; Continue Acquisition of Easements for Grouse: 1990, 1991)

8.8

HUNGRY HORSE DAM MITIGATION, , , , , , , , , , , . . 233

(Begin Advanced Design/Begin to I mplement

Elk/Mule Deer Project; Begin Advanced Design, Interagency Coordination, Site Prioritization, and Appraisals for Black Bear/Grizzly Bear,

Waterfowl, Terrestrial Furbearer Projects: 1987)

8,9

HUNGRY HORSE DAM MI TI GATION ,

(Continue Advanced Design Waterfowl, Terrestrial Furbearer, Black Bear/Grizzly Bear Projects;

Continue I mplementation/Monitoring of Elk/Mule

Deer Project: 1988)

8.10

HUNGRY HORSE DAM MI TI GATION

(Begin/Continue I mplementation of Waterfowl,

Elk/Mule Deer, Black Bear/Grizzly Bear

Projects: 1989-1991)

8.11

PUBLI C I NVOLVEMENT ON MI TI GATI ON PLANS ， ，，，，， ， ， , 235

(Fund Public Involvement Activities

Concerning Mitigation Plans)

8,12

FUND I MPLEMENTATI ON OF MI TI GATI ON PRIORI TIES ， ， ， ， ， , , 237 (Fund I mplementation of Mitigation Priorities and PIans Approved by the Councill) 
DEVELOP MONI TORING AND EVALUATION PROGRAM.

( Develop in Consultation with the Council, the Fish and Wildlife Agencies and Tribes, and Others a Monitoring and Evaluation Program)

.... I NNOVATIVE FUNDING OF HUNGRY HORSE/LIBBY

MI TI GATI ON , , , , , , , , , , , , , , , , , , , , 243

(Fund the Montana Wi Idlife Trust)

\section{FUTURE HYDROELECTRIC DEVELOPMENT ACTION ITEMS AND TECHNICAL SUBJECTS}

APPLICATI ON OF PROGRAM SECTI ONS 1204(a), (b), (c), AND (e) TO NEW PROJECTS , , , , , , , , , , , , 247

9.3 ASSESSMENT OF CUMULATI VE EFFECTS , , , , , , , , , , , , , 249 (Complete Study; Develop Methods: J une 1987

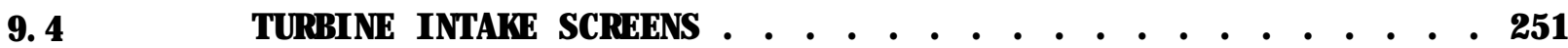
(Develop New Designs, Complete Tests, Report to Council: January 1989)

WORK AND EXPENDITURE PLAN ACTION I TEMS

10.1- EXPENDITURE AND OBLIGATION PLANS . . . . . . . . . 255

10.3 (Submit to Council by September 15 of Each'.

Year; Update and Submi t Information

Quarterly; Submi t Review of Previous Year;

Report Expenditures by Measure)

PROGRAM-RELATED, NON- MEASURE PROJECTS

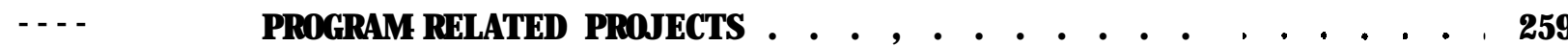

VIII, NON-ACTION ITEM PROJECTS , , , , , , , , . . . 265

IX. APPENDICES

A. NON-PROGRAM, I NTERNAL SUPPORT PROJECTS, , ..........

B. ENDANGERED SPECIES ACT PROJECTS, , , , , , , , A- 13

C. LETTERS OF COMMENT ON DRAFT

FY 1992 AI WP AND BPA RESPONSES

TO I SSUES RAI SED , , , , , , , , , , , , , A. 19 
Number

Page

1.

Ongoing, Deferred, and Completed Program Projects, , , , 3

2.

New Fy 1992 Program Projects, , , , , , , , , , 15

3.

Abbreviations Used in the Work PIan, , , , , , , , , 17

4.

Staffing Chart - Division of Fish and Wildlife, , , , , 34

5. $\quad 703$ (c) (1) Habitat I mprovement and Passage Enhancement

Stat us Report , , , , , , , , , , , , , , , , 58

6. Status of Action Item 8, 2: Wildlife

Consultations at FCRPS Facilities, , , , , , , , 222

7. Status of Action Item 8, 3: Wildlife

Mitigation Plans at FCRPS Facilities, , , , , , , 226

$$
\text { LIST OF FIGURES }
$$

Number

Page

1.

Fy 1992 Fish and Wildlife Program Budget Allocation

by Maj or Program Areas., , . , . , , , , , , , , 22 


\section{I NTRODUCTI ON}

\section{General}

The Columbia River Basin Fish and Wildlife Program (Program) was developed by the Northwest Power Planning Council (Council) in accordance wi th Public Law 96.501, the Pacific Northwest Electric Power Planning and Conservation Act (Act). The purpose of the Program is to guide the Bonneville Power Admi nistration (BPA) and other Federal agencies in carrying out their responsibilities to protect, mi tigate, and enhance fish and wildlife of the Columbia River Basin. The Act explicitly gives BPA the authority and responsibility to use the BPA fund for these ends, to the extent that fish and wildlife are affected by the development and operation of hydroelectric generation in the Columbia River Basin. The Columbia River Basin Fish and Wildlife Program Annual I mplementation Work PIan (AIWP) presents BPA's plans for i mplementing the Program during Fiscal Year (FY) 1992.

The AlWP reflects the primary goals of the Council's Action PIan (Section 1400 of the Programs: to provide a solid, timely, and focused basis for budgeting and planning. In addition, the AI WP provides a means to judge the progress and the success of Program implementation. The Al WP is based on the outline developed by the Policy Review Group (PRG) during step 1 of the annual cycle of the Implementation PIanning Process (IPP), which is described in Section III,

This Al WP has been organized and written to meet the specific needs of Program Action Items 10,1-10,3. The AI WP includes schedules with key milestones for Fy 1992 and beyond, and addresses the Action Items assigned to BPA in Section 1400 of the 1987 Program and in subsequent amendments.

All Program projects discussed in the Al WP are listed in Tables 1 and 2 according to their status as of May 21, 1991. Table 1 (pp. 3-14) Iists completed, ongoing, and deferred projects. Table 2 (pp, 15-16) Iists Fy 1992 new-start projects. "Ongoing" status indicates that the project started in Fy 1991 or before and that it is expected to continue through part or all of Fy 1992. "Deferred" means that BPA implementation has been postponed to FY 1993 or later. "Completed" indicates completion during Fy 1991. "New" denotes projects planned for BPA implementation in FY 1992.

A number of projects are expected to begin in late FY 1991 and have been listed in Table 1 of the AIWP as "Projected FY '91 starts," based on their projected start dates. Several other projects are expected to end in late fy 1991. These projects have been listed in Table 1 as "Projected Fy' 91 Completions," based on their projected completion dates.

FY 1992 AI WP

The Al WP continues to focus on individual Program Action ltems. Each Action Itementry is accompanied by the relevant Program measure language (or abstract), a statement of BPA's objectives in implementing the Action Item, a discussion of background and progress to date, and a summary of implementation plans for Fy 1991 to accomplish the Action Item.

The Al WP also presents plans for individual project i mplementation. Project level reporting has been condensed to tabular form wherever possible. Tables 
are subdivided into:
I. Completed Projects
II. FY 1991 Ongoing Projects
III. Deferred Projects (if applicable>
IV. New Projects

Within each of these four categories, appropriate information is provided, e.g., Project Number, Project Title, Date Completed, Results/Conclusions, Project Status, Schedule and Milestones, Anticipated Start Date, Reason for Deferral, and Project officer.

\section{Non-Program Activities}

BPA also funds some fish and wildlife activities that are not in the council's Program. Appendix A describes BPA's non-Program, internal support projects. These projects were not subject to review by the Policy Review Group and have been included in the AI WP to help the public to better understand what BPA is doing. Appendix B describes BPA's ongoing Endangered species Act projects.

\section{Abbreviations Used}

The Al WP uses many abbreviations to identify various agencies, organizations, and technical terms. Table 3 (pp, 19-20) lists the full name of each group, or the technical term, and the corresponding abbreviation used in the Al WP. 
TABLE 1. ONGOING, DEFERRED, AND COMPLETED PROGRAM PROJECTS

\section{PROJECT STATUS DEFINITIONS:}

ONGOING = BPA is currently implementing project, i. e., there is a signed agreement, and project is expected to continue into FY 92 .

FY 91 START = Project was in FY 91 AIWP as a NEWFY 91 Project; there is no signed agreement yet, but BPA expects to start

DEFERRED = Project was in FY 91 AI WP; BPA implementation has been postponed to a future fiscal year beyond FY 92.

COMPLETED = Project completed in FY 91. (Projects completed before FY 91 are not listed in the FY 92 AlWP.)

Fy 91 COMP = Project is expected to be completed in Fy 91. 
TABLE 1

FY 1992 WORK PLAN PROJECTS

ONGOING, DEFERRED. AND COMPLETED PROJECTS

\begin{tabular}{|c|c|c|c|c|c|}
\hline $\begin{array}{l}\text { ACTI ON } \\
\text { I TEM } \\
\end{array}$ & $\begin{array}{c}\text { TECHNI CAL } \\
\text { SUB]ECT }\end{array}$ & $\begin{array}{l}\text { PROJ ECT } \\
\text { NUMBER }\end{array}$ & STATUS & RPA & TITLE \\
\hline \multirow[t]{2}{*}{2.1} & WATER BUDGET & $87 \cdot 127$ & ONGOI NG & $\mathrm{FIIOl}$ & SMOLT MONITORING AND WATER BUDGET PROGRAM \\
\hline & MANAGE MENT & 83.6 & ONGOI NG & $\mathrm{FIIOI}$ & OPERATI ON/MAI NTENANCE OF BPA FISH TAGGING TRAILER \\
\hline \multirow[t]{5}{*}{2.2} & SMOLT & $83 \cdot 323$ & ONGOI NG & $\mathrm{FIIOl}$ & SMOLT MONITORI NG/ WATER BUDGET \\
\hline & MONI TORI NG & $84 \cdot 14$ & ONGOI NG & Fi10i & SMOLT MONITORING/ WATER BUDGET \\
\hline & & 87.401 & ONGOI NG & $\mathrm{FIIOl}$ & SMOLT SURVIVAL AND TRAVEL TIME \\
\hline & & $91 \cdot 28$ & ONGOI NG & $\mathrm{FIIOl}$ & PIT-TAGGING OF WILD CHINOOK IN I DAHO AND OREGON \\
\hline & & 91.40 & ONGOI NG & F2701 & BONNEVILLE DAM J UVENILE FISH SAMPLING FACILITIES \\
\hline
\end{tabular}

3.1 CONDUIT DESIGN NONE

4.1 ELLENSBURG NONE

SCREENS

HABITAT AND

PASSAGE IMPROVEMENT PROJECTS

\begin{tabular}{|c|c|c|}
\hline $83 \cdot 7$ & ONGOING & F1112 \\
\hline 83.359 & ONGOING & F 1107 \\
\hline 83.415 & ONGOING & F 1107 \\
\hline 83.436 & ONGOING & F1501 \\
\hline 84.5 & ONGOI NG & F1107 \\
\hline 84.6 & COMPLETED & F1107 \\
\hline 84.8 & ONGOING & FIIII \\
\hline 84.9 & ONGOING & FIIII \\
\hline $84 \cdot 11$ & ONGOING & $F 1109$ \\
\hline $84 \cdot 21$ & ONGOING & FIIII \\
\hline $84 \cdot 22$ & ONGOING & FIIII \\
\hline $84 \cdot 23$ & ONGOING & F 1501 \\
\hline $84 \cdot 24$ & ONGOI NG & F 1107 \\
\hline
\end{tabular}

WARM SPRI NGS HABITAT I MPROVEMENT

I DAHO HABITAT EVALUATION/I MPROVEMENT PROJECTS

SALMON RI VER HABI TAT ENHANCEMENT

ALTURAS LAKE

THREE MI LE DAM PASSAGE I MPROVEMENTS - O\&M

CLEARWATER RI VER SUBBASIN

CLEARWATER HABITAT ENHANCEMENT

I OHN DAY RI VER SUBBASIN

GRANDE RONDE RIVER SUBBASIN

WI LLAMETTE/CLACKAMAS RI VER SUBBASIN

MAI NSTEM, MI DDLE FORK, JOHN DAY RI VER

MI DDLE FORK \& TRIBUTARIES, JOHN DAY RIVER

CAMAS CREEK, I DAHO

84.24 ONGOING F1107

MARSH, ELK, UPPER SALMON RIVER, I DAHO 
TABLE 1 (cont.)

FY 1992 WORK PLAN PROJECTS

ONGOING, DEFERRED, AND COMPLETED PROJ ECTS

\begin{tabular}{|c|c|c|c|c|c|c|}
\hline $\begin{array}{l}\text { ACTI ON } \\
\text { I TEM } \\
\end{array}$ & $\begin{array}{l}\text { TECHNI C } \\
\text { SUB।EC }\end{array}$ & & $\begin{array}{l}\text { PROJ ECT } \\
\text { NUMBER }\end{array}$ & STATUS & RPA & TITLE \\
\hline \multirow[t]{21}{*}{4.2} & HABI TAT & AND & $84 \cdot 25$ & ONGOING & FIIII & GRAND RONDE HABITAT I MPROVEMENT PROJECT \\
\hline & PASSAGE & IMPROVE- & 84.62 & ONGOI NG & F1109 & TROUT CREEK RI PARIAN ENHANCEMENT \\
\hline & $\begin{array}{l}\text { MENT } \\
(\text { cont. })\end{array}$ & & $85 \cdot 71$ & ONGOI NG & FIIII & $\begin{array}{l}\text { SOUTH FORK JOHN DAY RIVER \& IZEE FALLS FEASIBILITY } \\
\text { STUDY }\end{array}$ \\
\hline & & & $86 \cdot 75$ & ONGOI NG & F 1501 & LITTLE NACHES RIVER PASSAGE \\
\hline & & & $86 \cdot 79$ & COMPLETED & F1109 & FI FTEENMI LE CREEK BASIN HABI TAT I MPROVEMENT \\
\hline & & & $86 \cdot 79.1$ & ONGOI NG & F1109 & FI FTEENMI LE CREEK — PHASE IV AND V \\
\hline & & & $86 \cdot 124$ & ONGOI NG & F1501 & little fall Creek passage facilities maintenance \\
\hline & & & $87 \cdot 100$ & ONGOI NG & FIIIO & UMATI LLA HABITAT I MPROVEMENT - USFS \\
\hline & & & $87 \cdot 100 \cdot 1$ & ONGOING & FIIIO & UMATILLA HABITAT I MPROVEMENT - CTUIR \\
\hline & & & $87 \cdot 100 \cdot 2$ & ONGOI NG & FIIIO & UMATI LLA HABITAT I MPROVEMENT - ODFW \\
\hline & & & $87 \cdot 104$ & COMPLETED & F2105 & PASSAGE I MPROVEMENTS AT WESTLAND DI VERSI ON - O\&M \\
\hline & & & $87 \cdot 104 \cdot 1$ & ONGOING & F 2105 & PASSAGE I MPROVEMENTS AT STANFIELD DIVERSION \\
\hline & & & $87 \cdot 104 \cdot 2$ & ONGOING & F 2105 & WESTLAND NON-FISH I MPROVEMENTS \\
\hline & & & $87 \cdot 416$ & ONGOI NG & F 1501 & MAXWELL DI VERSI ON I MPROVEMENTS - O\&M \\
\hline & & & $87 \cdot 416 \cdot 1$ & ONGOI NG & F2105 & COLD SPRINGS DI VERSI ON I MPROVEMENTS - O\&M \\
\hline & & & $88 \cdot 22$ & ONGOING & FIIIO & UMATILLA BASIN TRAP AND HAUL \\
\hline & & & $88 \cdot 116$ & ONGOI NG & F 1501 & TROUT CREEK O\&M \\
\hline & & & $89 \cdot 24 \cdot 1$ & ONGOING & FIIIO & UMATILLA BASIN PASSAGE FACILITY EVALUATION \\
\hline & & & $91 \cdot 15$ & FY 91 START & FIIPM & DEVELOPMENT OF STREAM HABI TAT I MPROVEMENT \\
\hline & & & & & & STRATEGIES/ STANDARDS \\
\hline & & & $91 \cdot 30$ & FY 91 START & F1107 & EAST FORK SALMON RIVER COMPLETION \\
\hline 4,3 & ROZA & & NONE & & & \\
\hline 4.4 & PROSSER & & NONE & & & \\
\hline \multirow[t]{3}{*}{4.5} & YAKI MA & PASSAGE & 85.62 & ONGOING & F1119 & PASSAGE I MPROVEMENT EVALUATI ON \\
\hline & & & $89 \cdot 90$ & ONGOI NG & F 2113 & YAKI MA PASSAGE PHASE 2 SCREENS PREDESIGN \\
\hline & & & 91.57 & FY 91 START & F 2113 & YAKI MA PHASE 2 SCREENS FABRI CATI ON \\
\hline
\end{tabular}


TABLE 1 (cont.)

FY 1992 WORK PLAN PROJECTS

ONGOING. DEFERRED, AND COMPLETED PROJECTS

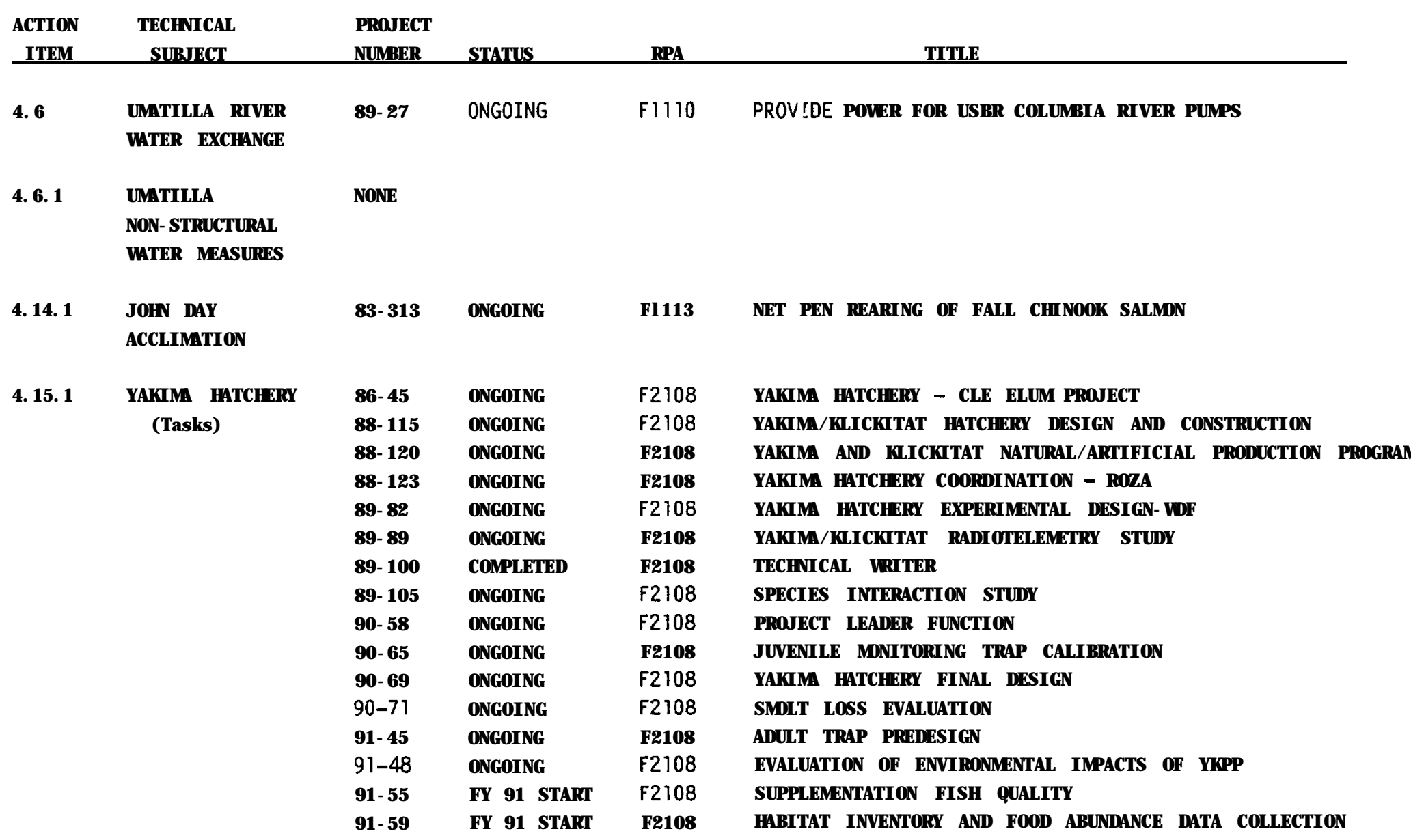


TABLE 1 (cont.)

FY 1992 WORK PLAN PROJECTS

ONGOING. DEFERRED, AND COMPLETED PROJECTS

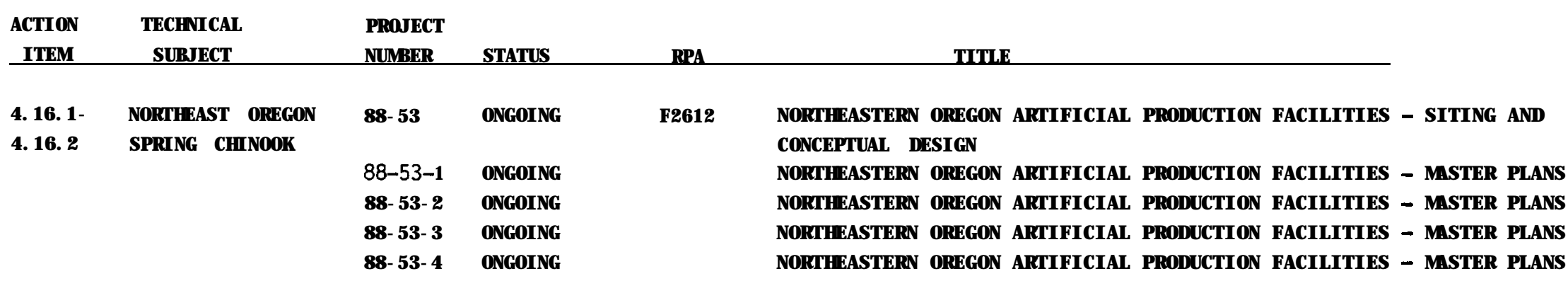

4.17.1 UMATILLA RELEASE

AND COLLECTION

$83.435-O N G O 1 N G$

F 1501

MINTHORN AND BONIFER SPRINGS ACCLI MATION FACILIITIES

4.17.2 UMATILLA

HATCHERY

84.33 ONGOING

84.33.3 ONGOING

F 2106

$91.14 \quad$ ONGOING

F2106

$90 \cdot 5$

FY 91 START

F2106

F 1121

UMATILLA HATCHERY CONSTRUCTION AND O\&M

UMATILLA HATCHERY TRIBAL FISH CULTURE TRAINING

UMATILLA SATELLITE FACILITIES

UMATILLA HATCHERY MONITORING AND EVALUATION

4.17.3 NEZ PERCE

83.350 ONGOING

HATCHERY

88.126

ONGOI NG

F2107

F 2107

4.17.4 CLEARWATER STUDY

88.I $5 \quad$ ONGOI NG

F 1107

I MPROVED HATCHERY

$83 \cdot 3 \quad 1$

COMPLETED

EFFECTI VENESS

$83 \cdot 36$

FY 91 COMP

F 1113

(Action Item $34.23 \quad 84.43$

FY 91 COMP

F 1113

in 1984 Program)

NEZ PERCE LOW-CAPITAL PRODUCTION FACILITIES

NEZ PERCE TECHNICAL SUPPORT

MAINSTEM CLEARWATER RI VER STUDY

EPI DEMI OLOGY AND CONTROL OF I NFECTIOUS DI SEASES

DEVELOPMENT OF DIETS FOR ENHANCED SURVIVAL OF SALMON

EVALUATION OF A SUBUNIT VACCINE AGAINST INFECTIOUS

HEMATOPOIETIC NECROSIS

\subsubsection{WI LLAMETTE RIVER NONE}

SPRING CHI NOOK

\subsubsection{PELTON DAM}

89.29 ONGOING

F 1113

PROPAGATION IN PELTON DAM LADDER

4.21 UPPER COLUMBIA NONE HATCHERY RELEASE 
TABLE 1 (cont.)

FY 1992 WORK PLAN PROJECTS

ONGOING, DEFERRED, AND COMPLETED PROJECTS

\begin{tabular}{lll} 
ACTION & TECHNICAL & PROJECT \\
ITEM & SUBJECT & NUMBER \\
\hline
\end{tabular}

STATUS

RPA

TI TLE

5.1 KNOWN STOCK NONE

ELECTROPHORESIS

GROUPS

6. 2 RESEARCH AREAS

OF EMPHASIS

$\boldsymbol{\infty}$

\begin{tabular}{|c|c|c|c|}
\hline \multirow[t]{13}{*}{ RES MORT/WB } & $82 \cdot 3$ & ONGOI NG & $\mathrm{F}|| 0 \mid$ \\
\hline & $82 \cdot 12$ & COMPLETED & $\mathrm{Fl|Ol}$ \\
\hline & $83.3 \quad 19$ & ONGOI NG & $\mathrm{Fl|Ol}$ \\
\hline & 87.413 .1 & COMPLETED & $\mathrm{Fl|} 0 \mathrm{l}$ \\
\hline & $87 \cdot 413 \cdot 2$ & ONGOI NG & $\mathrm{FI}|0|$ \\
\hline & $86.1 \quad 18$ & ONGOI NG & FIIPM \\
\hline & $\left(\begin{array}{ll}T 0 & 10\end{array}\right)$ & & \\
\hline & $88.1 \quad 34$ & FY 91 COMP & Fl| $0 \mid$ \\
\hline & 88.141 & ONGOING & $\mathrm{Fl|Ol}$ \\
\hline & $89 \cdot 107$ & ONGOING & $\mathrm{Fl|Ol}$ \\
\hline & 90.77 & ONGOI NG & F 1122 \\
\hline & 90.78 & ONGOI NG & F 1122 \\
\hline & $91 \cdot 17$ & ONGOI NG & Fl| 01 \\
\hline
\end{tabular}

MAGNITUDE/ DYNAMI CS OF PREDATOR-CAUSED MORTALITY ON JUVENILE SALMONIDS PREDATI ON INDEX AND WAYS OF REDUCING SALMONID LOSSES TO PREDATION PIT TAG RESEARCH

FISH SURVIVAL AND SMOLT PHYSIOLOGY/BEHAVIOR WORKSHOPS ANALYSIS OF HISTORIC DATA FOR ADULT AND JUVENILE SALMONIDS FEASIBILITY OF SATISFYING MODEL ASSUMPTIONS OF THE BURNHAM/ ANDERSON FISH SURVIVAL ESTIMATI ON TECHNI QUE MCNARY COLLECTION EFFICIENCY

USE OF ADVANCED PHOTOPERIOD TO ACCELERATE SMOLTIFICATION

EPI DEMI OLOGICAL METHODS FOR QUANTIFYING SURVIVAL

RELATI ONSHIPS FROM PIT TAG RELEASES OF SMOLTS

DEVELOPMENT OF A SYSTEM. WI DE PREDATOR CONTROL PROGRAM

SYSTEM-WIDE SI GNIFICANCE OF PREDATION ON JUVENILE SALMONIDS IN

COLUMBIA AND SNAKE RIVER RESERVOIRS

I NVESTI GATION OF FACTORS AFFECTING J UVENILE WI LD

SPRING CHINOOK SALMON ABOVE LOWER GRANITE DAM 
TABLE 1 (cont.)

FY 1992 WORK PLAN PROJECTS

ONGOING, DEFERRED, AND COMPLETED PROJECTS

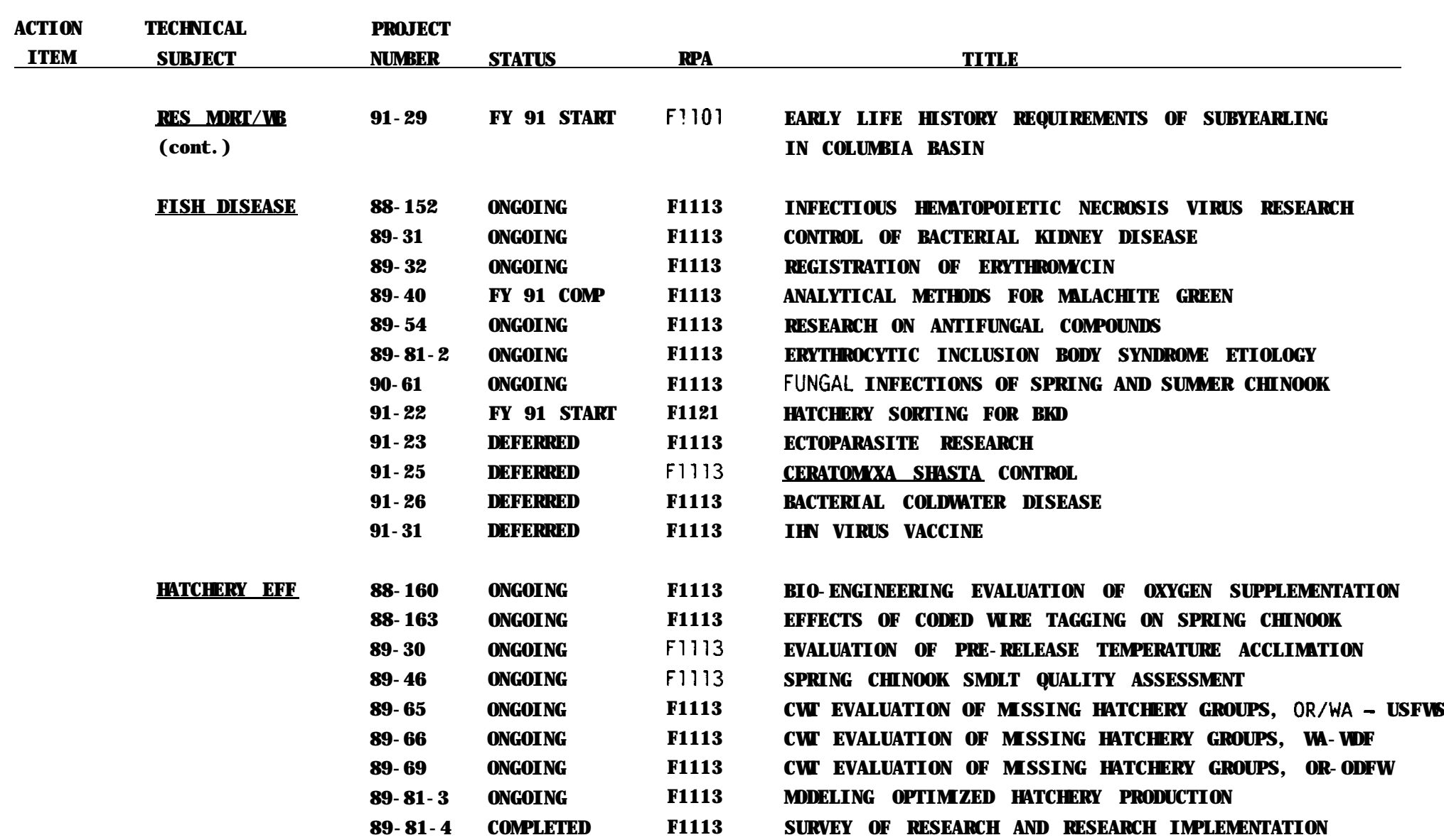


TABLE 1 (cont.)

FY 1992 WORK PLAN PROJECTS

ONGOING. DEFERRED. AND COMPLETED PROJECTS

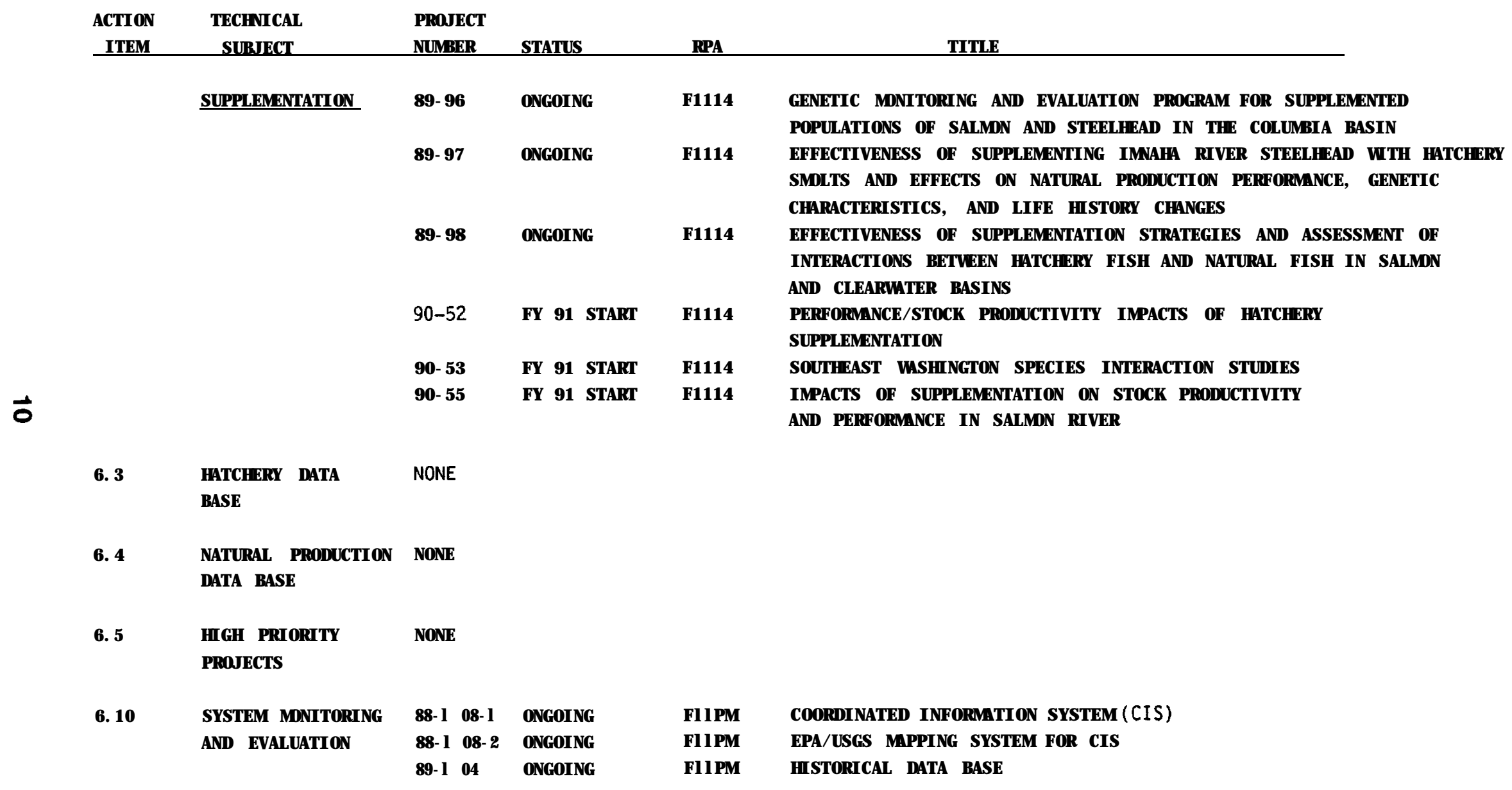


TABLE 1 (cont.)

FY 1992 WORK PLAN PROJECTS

ONGOING, DEFERRED, AND COMPLETED PROJECTS

\begin{tabular}{|c|c|c|c|c|c|}
\hline $\begin{array}{c}\text { ACTI ON } \\
\text { I TEM }\end{array}$ & $\begin{array}{c}\text { TECHNI CAL } \\
\text { SUBJECT }\end{array}$ & $\begin{array}{l}\text { PROJ ECT } \\
\text { NUMBER }\end{array}$ & STATUS & RPA & TI TLE \\
\hline \multirow[t]{2}{*}{6,12} & COORDI NATI ON AND & NONE & & & \\
\hline & CONSULTATI ON & & & & \\
\hline 7,1 & COLVILLE HATCHERY & $85 \cdot 38$ & ONGOI NG & F 1501 & COLVILLE HATCHERY OPERATION AND MAI NTENANCE \\
\hline 7.2 & COEUR D'ALENE & 90.44 & ONGOI NG & F 1202 & STREAM SURVEY， HATCHERY， HABITAT I MPROVEMENTS， AND MONITORING \\
\hline \multirow[t]{6}{*}{7,3} & KOKANEE SALMON & 88.62 & ONGOI NG & F 2203 & SPOKANE TRIBAL HATCHERY - GALBRAITH SPRINGS \\
\hline & HATCHERI ES & $88 \cdot 62 \cdot 3$ & COMPLETED & F2203 & CONSTRUCT HATCHERY RESIDENCE - GALBRAITH SPRINGS \\
\hline & & $90 \cdot 76$ & COMPLETED & & HATCHERY MANAGER TRAINING PROGRAM \\
\hline & & 90.86 & FY 91 COMP & F2204 & SHERMAN CREEK HATCHERY \\
\hline & & 91.46 & ONGOI NG & F1501 & SPOKANE TRIBAL HATCHERY O\&M \\
\hline & & $91 \cdot 47$ & FY 91 START & F 1501 & SHERMAN CREEK HATCHERY O\&M \\
\hline \multirow[t]{2}{*}{7.4} & LAKE ROOSEVELT & 88.63 & ONGOI NG & F1204 & LAKE ROOSEVELT MONITORING PROGRAM \\
\hline & & $90 \cdot 18$ & ONGOI NG & F 1204 & LAKE ROOSEVELT HABI TAT I MPROVEMENT PROJ ECTS \\
\hline \multirow[t]{2}{*}{7,5} & KOOTENAI I NDI AN & $88 \cdot 64$ & ONGOI NG & F1203 & DESI GN/ CONSTRUCT / OPERATE STURGEON HATCHERY \\
\hline & RESERVATI ON & & & & \\
\hline 7.6 & KDOTENAI RI VER & 88.65 & ONGOI NG & F1203 & ASSESS IMPACTS OF WATER LEVEL FLUCTUATIONS \\
\hline \multirow[t]{2}{*}{7,7} & KALI SPEL & 88.66 & FY 91 COMP & F1204 & ASSESS FISHERY I MPROVEMENT OPTIONS IN THE PEND OREILLE RIVER \\
\hline & RESERVATI ON & & & & \\
\hline \multirow[t]{2}{*}{7.10} & FUND PROJECTS & $88.1 \quad 56$ & ONGOI NG & F1202 & DUCK VALLEY RESI DENT FISH PROJECT \\
\hline & & $91 \cdot 27$ & FY 91 START & F2601 & FEASIBILITY STUDY - HATCHERY PRODUCTION ABOVE HELLS CANYON \\
\hline
\end{tabular}

7.11 MONTANA PROJECTS NONE 
TABLE 1 (cont.)

FY 1992 WORK PLAN PROJECTS

ONGOING, DEFERRED, AND COMPLETED PROJECTS

\begin{tabular}{|c|c|c|c|c|c|c|}
\hline $\begin{array}{l}\text { ACTI ON } \\
\text { ITEM }\end{array}$ & $\begin{array}{l}\text { TECHNI CAL } \\
\text { SUB।ECT }\end{array}$ & $\begin{array}{l}\text { PROJ ECT } \\
\text { NUMBER }\end{array}$ & STATUS & RPA & TI TLE & \\
\hline & STURGEON & 86.50 & ONGOI NG & F1203 & STURGEON STATUS AND HABITAT REQUI REMENTS & \\
\hline \multirow{3}{*}{7,12} & & $89 \cdot 44$ & FY 91 COMP & F 1203 & COLUMBIA RIVER WHITE STURGEON STUDY & \\
\hline & PEND OREILLE & & & & & \\
\hline & HATCHERY & $85 \cdot 339$ & ONGOI NG & F 1202 & KOKANEE STOCK STATUS AND EVALUATION OF CABINET GORGE & HATCHERY \\
\hline \multirow[t]{2}{*}{7.13} & KOOTENAI RI VER & NONE & & & & \\
\hline & MATERIALS REMOVAL & & & & & \\
\hline \multirow[t]{3}{*}{7.14} & DWORSHAK DAM & $87 \cdot 99$ & ONGOI NG & F 1202 & DWORSHAK DAM I MPACTS ASSESSMENT/ KOKANEE/ LI MNOL OGY & \\
\hline & I MPACTS & $87 \cdot 407$ & ONGOI NG & F 1202 & DWORSHAK I MPACTS ASSESSMENT/RAI NBOW/SMALLMOUTH BASS & \\
\hline & ASSESSMENT & & & & & \\
\hline \multirow[t]{5}{*}{7,15} & DRAWDOWN & 83.465 & ONGOI NG & & HUNGRY HORSE RESERVOIR LEVELS & \\
\hline & RE COMME NDATI ONS & 83.467 & ONGOI NG & F1201 & LI BBY RESERVOIR LEVELS & \\
\hline & MI TIGATION STATUS & NONE & & & CONSULTATIONS AMONG AFFECTED PARTIES SHOULD BEGIN & \\
\hline & REPORTS/ & & & & & \\
\hline & CONSULTATI ONS & & & & & \\
\hline 8.1 & LOSS STATEMENTS & 90.51 & ONGOI NG & $\mathbf{F} 1301$ & CLEARWATER RIVER OTTER STUDY & \\
\hline \multirow[t]{2}{*}{8.2} & LOSS STATEMENT & NONE & & & & \\
\hline & CONSULTATI ONS & & & & & \\
\hline \multirow[t]{2}{*}{8.3} & MI TIGATION PLANS & 88.44 & ONGOI NG & F 1301 & WI LDLIFE MITIGATION PLANNING FOR CHIEF JOSEPH DAM & \\
\hline & & 90.25 & FY 91 COMP & F1301 & LOWER COLUMBIA WILDLIFE MITIGATION PLAN & \\
\hline & & $90 \cdot 50$ & FY 91 COMP & F1301 & MI NI DOKA WI LDLIFE MITIGATION PLAN & \\
\hline
\end{tabular}


TABLE 1 (cont.)

FY 1992 WORK PLAN PROJECTS

ONGOI NG， DEFERRED， AND COMPLETED PROJECTS

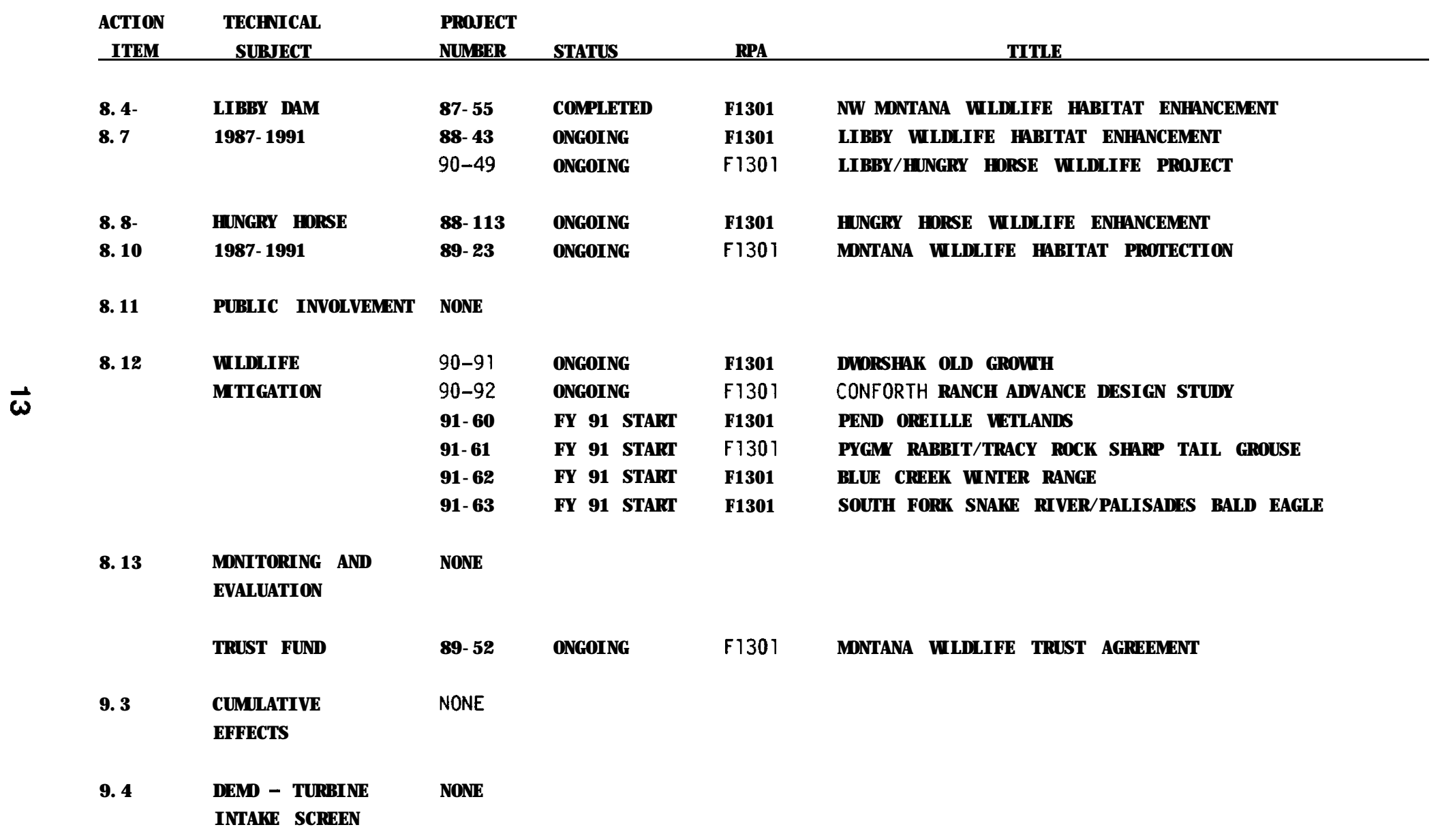


TABLE 1 (cont.)

FY 1992 WORK PLAN PROJECTS

ONGOING. DEFERRED. AND COMPLETED PROJECTS

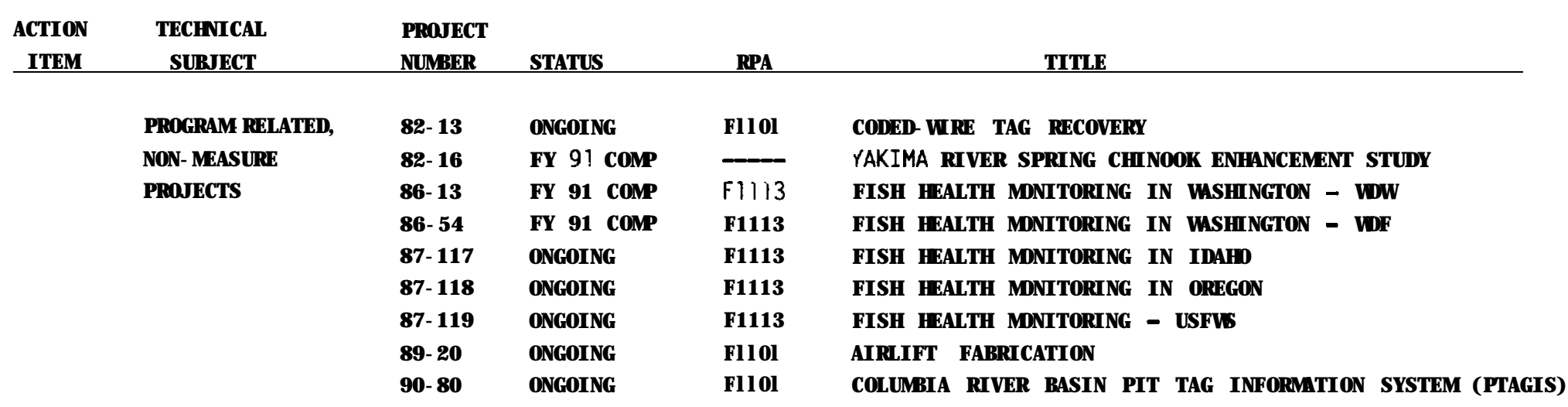

NON-ACTION ITEM PROJECTS: 
TABLE 2. NEW FY 1992 PROGRAM PROJECTS 
TABLE 2

FY 1992 WORK PLAN PROJECTS

NEW PROJECTS IN FY 1992

\begin{tabular}{|c|c|c|c|c|}
\hline ACTION I TEM & $\begin{array}{l}\text { TECHNI CAL } \\
\text { SUB]ECT }\end{array}$ & $\begin{array}{l}\text { PROJ ECT } \\
\text { NUMBER }\end{array}$ & RPA & TITLE \\
\hline 4,5 & YAKI MA PASSAGE & $92 \cdot 15$ & F 2113 & DRYDEN SCREENS DESIGN AND CONSTRUCTION \\
\hline \multirow[t]{5}{*}{4.15 .1} & YAKI MA HATCHERY & 90.64 & F 2108 & KLI CKI TAT RI VER MONI TORING \\
\hline & ( Tasks) & $90 \cdot 72$ & F 2108 & COMPUTER INFORMATI ON SYSTEM QUALITY CONTROL PROGRAM \\
\hline & & $90 \cdot 74$ & F2 108 & YAKI MA MONITORING AND EVALUATION PROGRAM \\
\hline & & $92 \cdot 5$ & F 2108 & EVALUATI ON OF THE YAKI MA PRODUCTION PROJECT \\
\hline & & $92 \cdot 14$ & F 2108 & HABI TAT DEFINI TI ON, ASSESSMENT, AND I MPROVEMENT \\
\hline 7,10 & FUND PROJECTS & $92 \cdot 10$ & F 1202 & FORT HALL BOTTOMS HABITAT ENHANCEMENT \\
\hline 8.12 & WI LDLIFE MITIGATION & $91 \cdot 16$ & $\mathbf{F} 1301$ & WI LDLIFE MITIGATION (OREGON, WASHINGTON, IDAHO) - FY 1992 \\
\hline \multirow[t]{3}{*}{8.13} & WI LDLI FE MONITORING AND & $92-x \times x$ & F 1301 & WI LDLIFE MONITORING AND EVALUATION PROGRAM \\
\hline & EVALUATI ON PROGRAM & & & \\
\hline & $\begin{array}{l}\text { PROGRAM-RELATED, } \\
\text { NON- MEASURE } \\
\text { PROJECTS }\end{array}$ & 90.60 & F 1101 & BYPASS EVALUATIONS \\
\hline
\end{tabular}

(0395W) 
TABLE 3, ABBREVIATI ONS USED IN THE WORK PLAN

Abbreviation

Act

AI WP

BIA

BCWD

$B K D$

$B L M$

BPA

$B P N L$

CBFWA

C. E

CCT

CIS

Council

CRB

CRI TFC

CRSP

CSKT

CTUIR

CTWSIR

cwu

$\mathrm{CY}$

DOE

EI BS

EIP

EIS

ELISA

EPA

EPRI

ESA

FCRPS

FDA

FDTWG

FONSI

FY

HEP

HE T WG

HU

I CF WRU

IDFG

IFIM

I HN

I PN

IPP

I RB

ISP

KCFS

KIT
Complete Title

Pacific Northwest Electric Power Planning and Conservation Act

Annual I mplementation Work PIan

Bureau of Indian Affairs

Bacterial Cold Water Disease

Bacterial Kidney Disease

Bureau of Land Management

Bonneville Power Administration

Battelle Pacific Northwest Laboratory

Columbia Basin Fish and Wildi ife Authority

Cost.effectiveness

Confederated Colville Tribes

Coordinated Information system

Northwest Power PIanning Council

Columbia River Basin

Col umbia River Inter-Tribal Fish Commission

Col umbia River Sal mon Passage

Confederated Salish. Kootenai Tribes

Confederated Tribes of the Umatilla Indian Reservation

Confederated Tribes of the Warm Springs Indian Reservation

Central Washington University

Calendar Year

Department of Energy

Erythrocytic Inclusion Body Syndrome

Early I mplementation Package

Environmental I mpact Statement

Enzyme-Linked I mmunosorbent Assay

Environmental Protection Agency

Electric Power Research Institute

Endangered Species Act

Federal Col umbia River Power System

Food and Drug Administration

Fish Disease Technical Work Group

Finding of No Significant I mpact

Fiscal Year

Habitat Evaluation Procedure

Hatchery Effectiveness Technical Work Group

Habi tat Unit

I daho Cooperative Fish and Wi I dlife Research Unit

I daho Department of Fish and Game

Instream Fl ow I ncremental Methodology

Infectious Hematopoietic Necrosis

Infectious Pancreatic Necrosis

I mplementation PIanning Process

Internal Review Budget

Integrated System PIan

Thousand cubic feet per second

Kalispel Indian Tribe 
( Continued)

Abbreviation

MAF
MDF WP
MEG
MOA
MOU
M/ WBT WG
NED
NEPA
NF
NFH
NMFS
NPT
ODFW
OHSU
OSU
OWRD
PI T
PSMFC
PMIS
PNUCC
PNWF HPC
PNWRS
PRG
PrOgr a
PSMFC
RFF
RM/WBE
RPA
SCS
SMEP
SPG
SPM
SPOC
SPT
SRG
STWG
TBA
TNC
TO
TWG
UCUT
UI
URB
URBFC
USACE
USBR
USFS
USFWS
UW

Complete Title

Million acre.feet

Montana Department of Fish, Wildlife and Parks

System Monitoring and Evaluation Work Group

Memorandum of Agreement

Memorandum of Understanding

Reservoir Mortality and Water Budget

Effectiveness Technical Work Group

Northwest Environmental Database

National Environmental Policy Act

National Forest

National Fish Hatchery

National Marine Fisheries service

Nez Perce Tribe

Oregon Department of Fish and Wildlife

Oregon Health Sciences University

Oregon State University

Oregon Water Resources Department

Passive Integrated Transponder

Pacific States Marine Fisheries Commission

Program Management Information System

Pacific Northwest Utilities Conference Commit tee

Pacific Northwest Fish Health Protection Committee

Pacific Northwest Research Station

Policy Review Group

Col umbia River Basin Fish and Wildlife Program

Pacific States Marine Fisheries Commission

Resources for the Future

Reservoir Mortality/Water Budget Effectiveness

Request for Project Authorization

Soil Conservation Service

System Monitoring and Evaluation Program

system and Subbasin PI anning Group

System PI anning Model

System PIanning Oversight Committee

Shoshone Paiute Tribe

Scientific Review Group

Supplementation Technical Work Group

To Be Announced

The Nature Conservancy

Task Order

Technical Work Group

Upper Col umbia United Tribes

University of I daho

Umatilla River Basin

Upriver Bright Fall Chinook

U.S. Army Corps of Engineers

U.S. Bureau of Reclamation

U.S. Forest service

U, S. Fish and Wildilfe Service

University of Washington 
TABLE 3. ABBREVIATI ONS USED I N THE WORK PLAN ( Conti nued)

Abbreviation

WDF
WDW
WEID
Wor k PI an
WS U
YIN

Complete Title

Washington Department of Fisheries Washington Department of Wildlife West Extension Irrigation District Annual I mplementation Work PIan Washington State University Yaki ma Indian Nation 


\section{FY 1992 BPA BUDGET ALLOCATION}

The FY 1992 Al WP reflects a high level of regional coordination and prioritization through the IPP. Anadromous fish will continue to be the area of emphasis of the Al WP, highlighted by the following "expense" activities: prioritized projects will be included in the first full year of implementation of the Integrated Systems PIan; Hydro Operations/Downstream Migration allocation is increased to incorporate the Non-Treaty Storage Agreement (water "rental" in Idahol; research projects in the fish health/artificial propagation and supplementation areas are reduced. Capital program expenditures include construction activities for the Yakima production facilities, Yaki ma Phase 2 screens, outplanting facilities for the Northeast Oregon Hatchery facilities, and the Stanfield Water Diversion in the Umatilla Basin.

Resident fish activities continue at a reduced level with the completion of the white sturgeon studies and most Council Program measures. The Al WP does include a "placeholder" for possible new measures associated with mi tigation for Libby and Hungry Horse reservoirs. No new capital activities are scheduled for FY 1992.

The wildlife program activities are scheduled at an increased funding level commensurate with the Fy 1990 Wildlife amendment to the council's Program. The Trust payment to Montana for mitigation activities is scheduled to continue.

Operation and maintenance activities will continue to increase wi th new facilities becoming operational. The first full year's operation of the Umatilla Hatchery is the most significant addition to this program area. 




Figure 1. FY 1992 Fish and Wildlife Budget Allocation by Major Program Areas 


\section{I. IMPLEMENTATION PLANNING PROCESS}

Background: On October 19, 1988, Bonneville Power Administration (BPA) and the Columbia Basin Fish and Wildlife Authority (CBFWA) signed a letter endorsing the I mplementation PIanning Process (IPP). The IPPis an annual, sequential, nine-step process by which BPA, in collaboration with the CBFWA, plans its implementation of the Columbia River Basin Fish and Wildlife Program (Program>. The nine steps of the IPP are:

Step 1. Program Policy Review

Step 2. Project Scoping

Step 3. Draft AIWP Development

Step 4. Public Review and Comment on Draft AI WP

Step 5. Publication of AI WP

Step 6. Project Specifications

Step 7. Project Selection and Negotiation

Step 8. Contract Awards

Step 9. Evaluation of I mplementation Progress

The IPP relies on three types of working groups to accomplish the nine steps:

1) the Policy Review Group (PRG); 2) the Scientific Review Group (SRG); and

3) Scoping Groups (SGs), formerly called Technical Working Groups.

Responsibilities: The primary role of the PRG is to provide BPA with the best possible guidance and recommendations, from a policy perspective, on the direction, emphasis, and funding of Program implementation. Most of the PRG's activities occur during step 1 of the IPP, Program Policy Review. The PRG is comprised of senior-level representatives from the CBFWA, BPA, Northwest Power PIanning Council, utilities, U.S. Forest Service, environmental groups, and other interested parties.

The SRG provides the PRG and BPA with objective scientific/technical advice and recommendations related to implementation of the Program. The SRG also prepares an annual evaluation report on implementation progress in step 9 of the IPP. The SRG is comprised of senior-level scientists from the Northwest and other regions of the country.

The SGs assist BPA with scoping of projects (step 2), responding to public comments (Step 4), and development of project specifications (step 6).

Currently, there are seven IPP SGs: Wildlife, Resident Fish, Columbia and Snake River Flow and Passage, Artificial Propagation, Habitat, Supplementation and Genetics, and Tributary Passage. These SGs are comprised of the region's technical experts in specific areas of expertise. The IPP provides a process to create additional SGs if they are needed.

BPA is responsible for developing the Al WP (step 3 ), i mplementing the public 
review process (Step 4), publishing the AI WP (Step 5), initiating procurement activities (Step 6), selecting contractors (Step 7), and awarding contracts (Step 8). BPA representatives also participate with the SGs in IPP Steps 2, 4 , and 6 .

Progress: In FY 1991, the PRG continued to meet as needed to accomplish IPP tasks. The PRG provided BPA with funding-level recommendations on BPA's FY 1992.1993 Fish and Wildlife Program Internal Review Budget (IRB). The PRG also developed the Outline of the Draft FY 1992 AlWP (see Section IV. Of the AIWP). The Draft FY 1992 AIWPis based on this outline, which represents the PRG's recommendations to BPA regarding FY 1992 Program implementation. The SGs contributed to the development of the Draft FY 1992 AI WP. The SRG continued to provide BPA and the PRG with objective advice on the scientific aspects of Program implementation. Because the IPP is a unique and relatively new program, BPA has conducted, and continues to conduct, educational efforts to familiarize IPP participants with their roles and responsibilities.

Plans: In FY 1992, the IPP will continue to provide an opportunity for the fish and wildlife agencies, Tribes, and other interested parties to participate with BPA in planning its implementation of the Program. Step 1 of the fourth annual IPP cycle, during which FY 1993 i mplementation will be planned, is expected to begin in August 19g1. The SRG will develop its second annual evaluation report on Program implementation in July 1991; this report is expected to provide valuable technical recommendations for use in planning FY 1993 Program implementation. The SRG and SGs will continue to meet as needed throughout FY 1992.

Copies of the complete IPP document and the Terms of Reference for the PRG, $S R G$, and $S G s$ are available from:

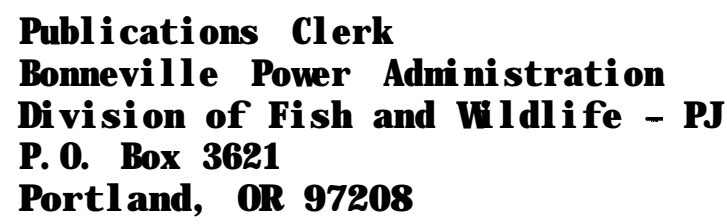




\section{POLICY REVIEW GROUP'S OUTLINE OF THE DRAFT AIWP}

The Policy Review Group (PRG) provides critical guidance at the beginning of the annual Implementation PIanning Process (IPP) cycle. That guidance must recognize and seek to balance the technical/scientific requirements of Program measures and the political, legal, and institutional realities existing in the Basin.

In Step 1 of the annual IPP cycle, the PRG considers knowledge gained through previous Program implementation, ongoing research, and other related planning activites in order to provide clear and concise recommendations on:

- policy matters as related to Program i mplementation;

- Program components to be emphasized;

- prioritizing technical subjects; and

- funding levels required for support.

These recommedations are made to BPA and serve as foundations for the technical planners in the scoping Groups.

As called for in step 1 of the IPP, the PRG developed recommendations to provide guidance during the development of the Draft FY 1992 AI WP. The PRG's recommendations include general policy guidelines (Policy Guidance for Draft FY 1992 AIWP), as well as specific guidance for each of the seven scoping Groups (Guidance for Scoping Groups - FY 1992 AIWP):

\section{Policy Guidance for Draft FY 1992 Al WP}

Anadromous Fish:

1. Anadromous Program implementation should focus on areas and stocks of emphasis consistent wi th decisions occuring in Council forums.

2. Projects should maintain or enhance productivity while ensuring genetic integrity of the Basin's resources.

3. Emphasis should be on fish production using adaptive management and evaluation consistent with Council's system Monitoring and Evaluation Program.

4. Sound biological escapement objectives should be identified for each stock proposed for project funding.

5. Project proposers must demonstrate how habitat enhancement projects:

a. address limiting factors,

b. maintain or increase fish production,

c. have the potential to be evaluated. 
Project proposers must be able to manage habitat enhancement investments to insure project effectiveness.

6. Determining whether supplementation works in the near and long term is a priority.

7. I pp participants should not develop preliminary project proposals related to the Integrated System PIan or early implementation actions until requested by the PRG or BPA.

8. Emphasis should be placed on collection of better scientific data on the relationship of mainstem flow and passage to fish survival.

Wi I d i fe:

9. Selection and implementation of wildlife projects must be consistent with the standards and priorities set forth by the council. Projects should be developed to minimize expenditures on planning. For similar projects directed at the same biological objective, strong consideration will be given to projects which exhibit the most favorable (lowest) planning to implementation cost ratios.

\section{Resident Fish:}

10. Resolution of funding sources for resident fish substitution measures above Hells Canyon Dam should be pursued as a high priority.

\section{General:}

11. Increased emphasis should be placed on cost-effective programs.

12. Competitive procurement, partnerhips, and other cost-sharing arrangements to increase the benefits of ratepayer-funded activities should be promoted.

\section{Guidance For Scoping Groups - FY 1992 AI WP}

\section{General Guidance:}

- Funding for new Fy 1992 anadromous fish projects is available only in RPA FllPM under Project 91-10, "I mplement Subbasin PIans." Funds were placed in this "placeholder" project in anticipation of council action on Subbasin PIans. Once the Council has amended the Integrated System PIan or early implementation actions into the Program, and the PRG has recommended its areas of emphasis to BPA, the funds under Project 91.10 will be used to i mplement multiple projects in various technical areas and will be allocated to the appropriate RPAs.

- BPA will notify SGs (through IPP Coordinator when it is time to begin scoping new projects.

- Until BPA notifies SGs, IPP participants should not submit preliminary project proposals to BPA, and SGs should not scope projects related to implementing System and Subbasin PIans. 


\section{Specific Instructions to scoping Groups:}

1. Wi I dl ife

- Do not scope new Fy 1992 projects at this time. A Program Solicitation may be used to solict new projects, rather than having the SG scope new projects as part of IPP step 2 .

- If and when it is appropriate, BPA will notify SG (through IPP Coordinator) to begin project scoping (IPP Step 2) for new FY 1992 wildlife projects and transmit any additional policy guidance from the PRG.

2. Resident Fish

- Do not scope new projects at this time. A total of $\$ 1$ million is available for project(s) to mi tigate for Hungry Horse and Libby dams. However, a Program amendment is needed before the SG can scope projects.

3. Columbia and Snake River Flow and Passage

- Do not scope new Fy 1992 projects (no funds available for new projects).

- Review the need for Project 91-40, Bonneville Dam Juvenile Fish Sampling Facilities, Is construction of PlT-tag detection facilities feasible, given the large amount of spill at Bonneville Dam?

4. Artificial Propagation

- Do not scope new projects (no funds available for new projects).

- SG should prioritize ongoing projects (and new Fy 1991 projects that have not started yet, but would be ongoing in Fy 1992) in RPA F1113 in preparation for $\$ 737 \mathrm{~K}$ reduction by $P R G$.

5. Habitat

- Do not scope new projects unt il not ified by BPA. See General Guidance above.

6. Supplementation/Genetics

- Do not scope new projects (no funds available for new projects).

1. Tributarv Passage

- Do not scope new projects (no funds available for new projects).

- Review deferred Project 87-112, Orofino Creek Passage, for possible re.start in Fy 1992. Because Fy 1992 funds for Project 87.112 would come from the "I mplement Subbasin PIans" placeholder project, the SG should answer the question: Is starting up Project 87.112 in Fy 1992 
a higher priority than starting potential new projects to i mplement Subbasin PI ans? 


\section{SYSTEM PLANNING ACTIVITIES}

BPA actively participates in two Council-managed system planning programs, System and Subbasin Planning and System Monitoring and Evaluation. These two programs will strongly influence future Program direction and will ultimately affect BPA's i mplementation of the Program, its evaluation and monitoring efforts, and its future Fish and Wildlife Program budget levels. The current status and plans of these two programs are presented below.

System and Subbasin PI anning

Responsibilities: The Council funds the activities of the fish and wildife agencies and tribes to develop an Integrated system Plan, utilizing 31 separate Subbasin PIans. The fish and wildlife agencies and tribes organized committees at the system and subbasin levels for completing this task. The subbasin level committees were responsible for collecting information and developing drafts of specific Subbasin Plans. The system level committee, the System PIanning Group (SPG), was responsible for developing the format for the plans, guiding the subbasin planners, and reviewing draft plans. The SPG has developed the Integrated System PIan (ISP). The Council has organized another committee at the system level, the system PIanning Oversight Committee (SPOC), that has identified and is addressing major issues that have been and will be part of the system planning process.

Progress: The council's contract with the fish and wildlife agencies and tribes through the Pacific states Marine Fisheries Commission calls for nine products over the life of the planning process. PIanning began in september 1987, and several products have been completed to date. These products include the prelimi nary information reports that contain information needed to evaluate the production potential of the subbasins and thereby identify realistic objectives for production, draft Subbasin Plans above Bonneville Dam that include proposed objectives for production, the preliminary system analysis report above Bonneville Dam that analyzes the proposed objectives for consistency, and final Subbasin Plans above Bonneville Dam that include recommended and al ternative strategies for meeting the proposed objectives.

The same products have been completed for subbasins below Bonneville Dam. The draft ISP has been issued for public review, with a final produced in May 1991. BPA has initiated a process with its contrasts.r, Resources for The Future (RFF), to develop a cost-effectiveness (C.E) analys is process, which will become one of the criteria for selecting and implementing proposed actions from the ISP and the subsequent Program amendment process. C.E analysis programs and processes were developed by RFF, and were tested on the upper Columbia Basin subbasins. The C.E analysis was applied to other selected subbasin plans above Bonneville Dam after consultation with numerous Basin entities.

PIans: The ISP recommends objectives and strategies for sal mon and steel head production in the 31 subbasins of the Columbia River Basin. This plan, will be utilized as part of the Program amendment process that will extend into August 1992. The results of that amendment process will provide guidance for funding activities in BPA's implementation of the Fish and Wildlife Program in the 19g0s. An Early I mplementation Package, i,e, a list of projects from the ISP and other possible sources, will be implemented to protect or rebuild marginal anadromous fish runs in the Columbia Basin. BPA is participating in 
the system planning process to assist in the definition of strategies for meeting sal mon and steelhead production objectives and to help make the link between the planning process and implementation scheduling in fiscal years beyond 1992. BPA participation in the SPG and the SPOC will continue on a regular monthly basis through the end of the planning process.

\section{System Monitoring and Evaluation}

Responsibilities: The Council's Monitoring and Evaluation Group (MEG) is charged with: formulating a System Monitoring and Evaluation Program (SMEP), maintaining the System PIanning Model (SPM), integrating Subbasin PIans, recommending formats for system and Subbasin Plan reports (including habitat capacity, genetic impacts, production, and cost of alternative strategies), developing a Coordinated Information system (CIS), and evaluating and disseminating research results.

Progress: MEg subcommittees have been formed to address: SPM maintenance, genetics, analytical methods, system PI an integration, and the CIS. These efforts are underway.

Plans: The Council will prepare a work plan as the basis for direct BPA funding. After the SMEP is adopted by the Council, BPA funding of MEG activities will be formalized as a Program Action ltem. MEg will focus on gaining public support for and eventual adoption of SMEP, CIS implementation, and System Plan integration.

Long-Term Role: MEg functions will continue as a result of its role in measuring systemwide progress, monitoring compliance with Program policies, integrating system plans, maintaining the SPM, guiding development and maintenance of the $C I S$, and evaluating research results for application to Program actions. 


\section{FISH AND WILDLIFE DIVISION ORGANIZATION AND STAFF}

The Division of Fish and Wildlife develops, coordinates, and manages BPA's Fish and Wildife Program pursuant to the requirements of the Pacific Northwest Power PIanning and Conservation Act (Act). The Division was reorganized under BPA's Most Efficient Organization concept in late 1987. As a result, the functions of the Division's branches and sections were redefined. Table 4 contains a current staffing list for the Division. Branch and section titles and functions are as follows:

Fisheries Integration Branch

This Branch reviews and analyzes proposed BPA policies, programs, and plans for their consistency with BPA's fish and wildlife obligations under the Act and recommends standards, criteria, policy, or procedures necessary to ensure equitable treatment of fish and wildlife in BPA's decision making process; evaluates hydroelectric operations for fish and wildlife i mpacts and needs and recommends balanced operations; reviews and analyzes policies, programs, plans, and legislation of external entities to determine their impact on BPA's Fish and Wildlife Program; represents and integrates the biological and Fish and Wildlife Program requirements into the development of agency policy, programs, and plans; and develops and admi nisters research and monitoring contracts directed at resolving fish passage problems at hydroelectric facilities. The Branch represents BPA on the Reservoir Mortality and Water Budget Effectiveness Technical Work Group and manages BPA's implementation of major sections of the Program.

\section{Biological Planning Branch}

This Branch provides biological/technical expertise to the Division for planning for and implementing the Program. It prepares and monitors the fish and Wildlife Program budget; develops and maintains the Division's Program Management I nformation System (PMIS); develops annual implementation work plans; provides cost.effectiveness analysis and determination for funding actions; develops and maintains the fish and wildlife mitigation accounting records; represents BPA on technical planning work groups established by the Council and the CBFWA; and manages BPA's implementation of major sections of the Program.

Program Planning section

The Program PIanning Section oversees and provides BPA's representative to: Council TWGs addressing supplementation of wild fish with hatchery fish, System and Subbasin Planning, and system Monitoring and Evaluation. It oversees and coordinates the Implementation PI anning Process and develops the Annual I mplementation Work PIan. It oversees implementation of areas of the Program dealing with natural production of salmon and steelhead. It develops methods for and oversees the application of cost-effectiveness criteria in the selection of activities to be i mplemented by BPA and develops and maintains BPA's fish and wildlife mitigation accounting records. 


\section{Biological Research Section}

This section provides biological technical expertise necessary to assist the Division's development of the Program Annual I mplementation Work PIan and annual budget planning documents and to assist in the implementation of complex major projects; serves as BPA's representative to the council's Hatchery Effectiveness Technical Work Group (HETWG) and Fish Disease Technical Work Group (FDTWG); develops scopes of work and oversees the procurement of projects identified in the annual Work Plan; and serves as COTR for subsequent contracts. It oversees areas of the Program addressing artificial production (including fish health) of salmon and steelhead, resident fish, and wildlife and develops and maintains the Division's official contract and project files.

\section{Project Management Branch}

The Project Management Branch manages the implementation of fish and wild ife development projects of the Program; provides comprehensive oversight and management of such projects appropriate to their cost, policy precedents, political sensitivity, biological complexity, and associated controversy; formulates and directs the coordination efforts both within BPA and externally with Federal and State agencies, Tribes, utility groups, and the public to define, develop, and implement proposals; manages the development of the comprehensive long-term operations and maintenance agreements at tendant on such projects; and manages and directs the allocation of financial and personnel resources necessary to implement, operate, and maintain capital and expense projects.

This Work PIan refers to four different personnel titles. It is helpful for the reader to understand the responsibilities and authorities of these positions, should questions or comments arise about BPA procurement, projects, or i mplementation. The positions are:

\section{PROJ ECT MANAGER}

Individual assigned working responsibility for the coordinated and timely implementation of one or more "major" projects within the Program. All Project Managers are assigned to the Project Management Branch.

PROJECT BIOLOGIST

Biologist who serves as the lead for all biological activities related to a major project. During project implementation, the Project Biologist oversees all biological aspects of the project and provides biological information to the Project Manager.

PROJECT OFFICER

Individual responsible for the management of "non-major" projects; often serves as the COTR for any contracts associated wi th the project.

CONTRACTI NG OFFI CER'S TECHNI CAL REPRESENTATIVE (COTR)

Individual responsible to BPA's contracting officer for the development, 
negotiation, and management of contracts for specific goods and services associated with fulfillment of Program measures. 
TABLE 4, STAFFING LIST

DI VISION OF FISH AND WILDLIFE

$9 / 9 / 91$

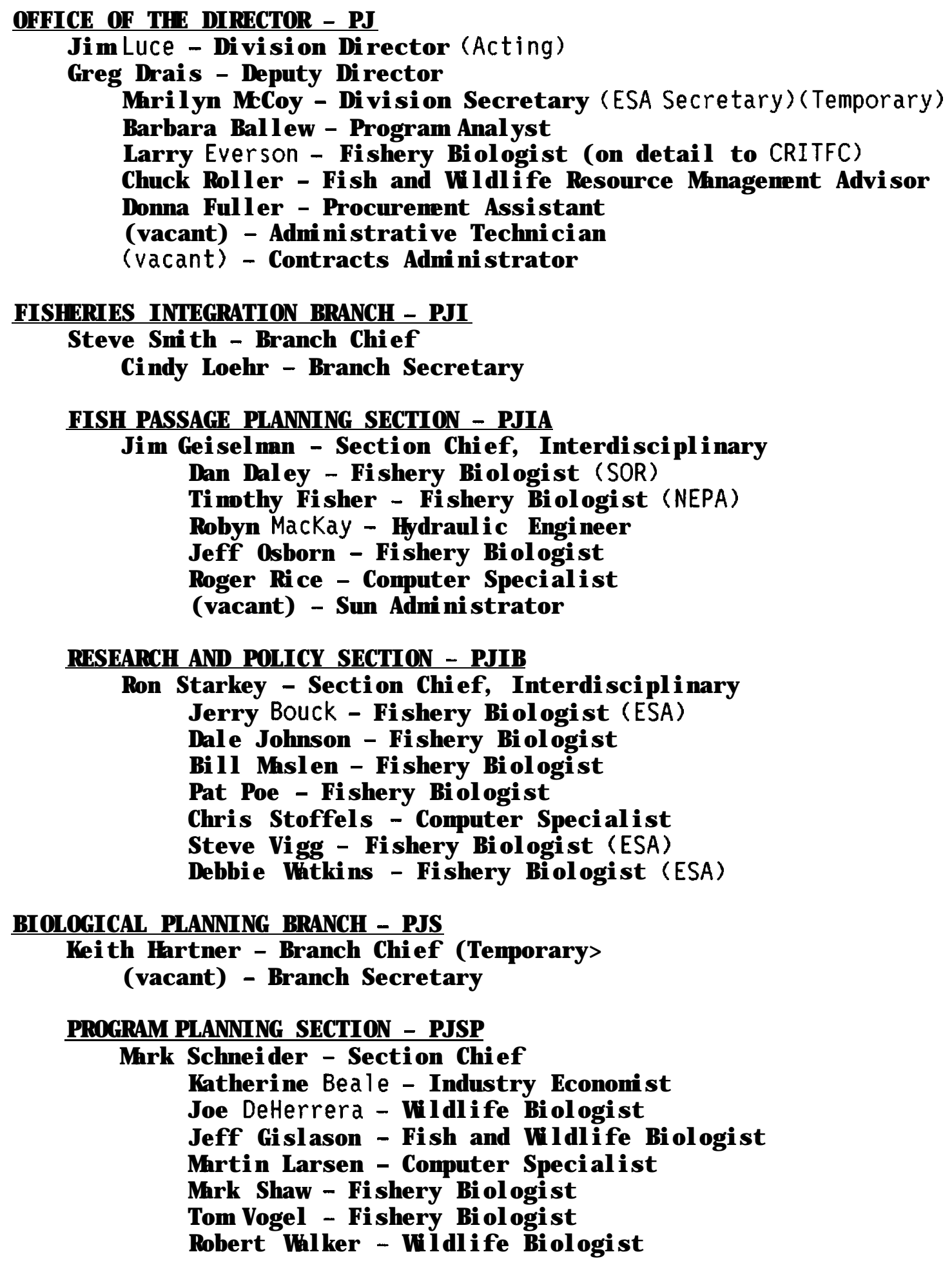


TABLE 4, STAFFING LIST

DIVISION OF FISH AND WILDLIFE

9/9/91

( Continued)

BIOLOGICAL RESEARCH SECTION - PISR

Ron Morinaka - Section Chief (Temporary)

Robert Austin - Fishery Biologist

Jerry Bauer - Fishery Biologist

Fred Holm - Fishery Biologist

Al an Ruger - Fishery Biologist

(vacant) - Fishery Biologist

(vacant) - Fishery Biologist (Genetics)

FISH \& WILDLIFE PROJECT MANAGEMENT BRANCH - PIW

Robert Beraud - Chi ef

(vacant) - Branch Secretary

Steve Levy - Project Manager

Jay Marcotte - Project Manager

Rick Stoots - Project Manager

J udy Woodward - Project Manager

(vacant) - Project Manager

Yaki ma Project office - PJW. 5

Tom Clune - Project Manager

Sharon Rice - Secretary 
VII. PROGRAM PLANS BY ACTION ITEMS

ANADROMOUS FISH ACTION ITEMS

AND TECHNICAL SUBJECTS 
2.1 WATER BUDGET MEASURES

303(a) [Abstract] The Federal project operators and regulators shall provide the fish and wildlife agencies and Tribes with a total Water Budget of $78 \mathrm{kcfs}$. months $(4.64 \mathrm{Maf})$. It is to be divided into 58 kcfs-months (3.45 Maf) at Priest Rapids Dam and 20 kcfsmonths (1.19 Maf) at Lower Granite Dam, and used during April 15 through June 15.

303(b) [Abstract] BPA shall fund the establishment and operation of a Fish Passage Center, including funds for two Fish Passage Manager positions and for technical and clerical support. This support will assist the Fish Passage Managers in: 1) planning and implementing the annual smolt monitoring program called for in Section $304(d)(2) ; 2$ ) developing and implementing flow and spill requests; and 3 ) monitoring and analyzing research results to assist in implementing the Water Budget and spill planning. The Fish Passage Center will function as the primary program center for housing data and information regarding juvenile fish passage.

303(c) [Abstract] The Federal project operators, Fish Passage Managers, fish passage advisor, and power system operators will coordinate system operations for the current year and develop experimental use and accounting procedures for both the mid-Columbia and Snake River Water Budgets. Experimental Water Budget procedures shall be implemented for at least water years 1987 and 1988. This committee also shall evaluate alternative Water Budget implementation procedures and report to the Council.

\section{ACTI ON ITEM ACTIVITY SUMMARY:}

\section{Objectives:}

To provide adequate flows for fish migrations, and to insure clear and timely integration of fish reauirements and hydrosystem operational decisions.

\section{Backsround and Proaress to Date:}

The council recognized that the agencies and Tribes lacked the expertise to work with the owners and operators of the hydrosystem. The agencies and Tribes needed such expertise to assure that the Water Budget would be considered in all phases of hydrosystem planning and operation. The council, therefore, specified that BPA $f$ und two Fish Passage Managers, one for the Tribes and one for the agencies. BPA has funded the operation of the Fish Passage Center and the Fish Passage Data Information System since 1983. 
PI ans:

BPA plans to continue to fund the operation of the Fish Passage Center, the Fish Passage Managers and support staff, and the Fish Passage Data Information system to benefit the integration of fish and hydrosystem operational requirements, and to provide increased adult returns by using supplemental flows in a timely fashion. 
None.

11. FY 1991 ONGOING PROJECTS

PROJ ECT

NUMBER

$87 \cdot 127$

$S$ molt Monitoring and Water Budget Programs - PSMFC and CRITFC

Proiect officer: D. Johnson

Objectives: Fund the operation of the Fish Passage Center and provide Water Budget flows for shaping between April 15 and June 15 to reduce hydrosystem impacts on juvenile outmigrations.
PROJECT STATUS

Date initiated: February 1987

Results/Conclusions: BPA funded the operation of the Fish Passage Center and the Fish Passage Data Information system in FY 1990.
SCHEDULE AND MILESTONES

1. Continuing: BPA will continue to fund the operation of the Fish Passage Center and the Fish Passage Data Information System and to provide Water Budget flows for shaping annually.

2. Continuing: Contractors will guide the smolt monitoring program; they will provide an annual report by November 1 of each year and a $5 \mathrm{molt}$ monitoring program by December 1 of each year.

Smolt monitoring, as provided under the Fish Spill MOA, is also conducted under Project 87.127:

Smolt Monitoring/spill

Proiect officer: W. Maslen

Objectives: Provide monitoring of $j$ uvenile salmonid outmigrations at Lower Monumental and I ce Harbor Dams, as pro. vided in the Fish spill Memorandum of Agreement (MOA), to determine smolt numbers, migration timing, and species composition. This information will be used by the fishery agencies and Tribes to manage spill for fish passage under the terms of the MOA.
Date Initiated: 1989

Results/Conclusions: Gatewell monitoring was conducted at Lower Monumental Dam for 12 hours/day /a 4 hour/day extension over the ongoing Smolt Monitoring Program). By mutual agreement of the parties, monitoring was not conducted at I ce Harbor Dam in 1991.
1. FY 1992 and beyond: Under the terms of the fish spill MOA, monitoring at Lower Monumental shall be discontinued with installation of bypass

2. FY 1992: By mutual agreement of the parties, monitoring is not planned for Ice Harbor. 
PROJ ECT

NUMBER

83-6 $\frac{\text { TITLE }}{\text { Operation and Maintenance of }}$ BPA Fish Marking Trailer - USFWS

Project officer: W. Masl en

Obiectives: Using mobile fish

marking trailers, conduct

marking (coded-wire tags, freeze

brand, and PIT tags) of juvenile

salmonids throughout the region

for BPA-funded projects, in.

cluding the Columbia River Basin

Smolt Monitoring Program and

Yakima Basin Monitoring and

Evaluation.

$\stackrel{+}{N}$

11I. NEW PROJECTS

None.

\section{PROJECT STATUS}

ate initiated: 1983

Results/Conclusions: A total of ap-

proximately 2.2 million fish were marked

in 1991.

\section{SCHEDULE AND MILESTONES}

Continuing: BPA will continue to fund marking of various fish groups for BPA-funded projects 
2.2 SMOLT MONITORING PROGRAM

$303(d)$

[Abstract] BPA shall fund an annual smolt monitoring program to be conducted by the agencies and Tribes. The monitoring program will provide information on the mi grating characteristics of the various sal mon and steelhead stocks and wi ll include:

1. Field monitoring of smolt movement to determine the best timing of storage releases;

2. Coordination of runoff forecasts wi th water budget usage and shaping;

3. Continuous monitoring of runoff conditions and fish movement at Lower Granite and Priest Rapids dams to provide information to allow changes in water budget usage if actual runoff conditions are inconsistent with runoff forecasts; and

4. Coordination of hatchery releases with water budget usage.

\section{ACTI ON I TEM ACTIVITY SUMMARY:}

Objectives:

To determine where all major groups of migrating, juvenile hatchery and wild fish are in the hydrosystem. This information is used to i mplement the Water Budget and communicate spill requests.

Background and Progress to Date:

Starting in the 1970s, spring flows in the Columbia River changed dramatically with the completion of major headwater storage projects. This change helped flood control and power generation, but slowed the travel time of the outmigration. This resulted in increased exposure to predation and increased mortality of the juvenile salmon and steelhead. The council sought to reduce the mortality associated wi th the downstream migrations by increasing the spring flows. A Water Budget volume was derived from agencies' and Tribes' recommendations and was specified for the mid-columbia and lower snake rivers. To be able to implement the Water Budget effectively, the smolt monitoring program has evolved to sample the downstream-juvenile migrations at numerous key locations throughout the hydrosystem.

PI ans:

BPA plans to continue funding the smolt monitoring program to improve the timely integration of the juvenile salmon and steelhead out migration with the operation of the hydrosystem. 
None.

\section{FY 1991 ONGOING PROJECTS}

PROJ ECT

NUMBER

$84-14$

\begin{abstract}
Monitoring of Downstream Salmon and Steelhead at Federal
\end{abstract}

Hydroelectric Facilities - NMFS

Project of ficer: V. Jagendorf

Obiectives: To monitor the seaward migration of juvenile salmon and steelhead at

John Day, and Bonneville Dams as part of the Columbia River Smolt Monitoring Program; to provide daily fish capture and condition data, as well as dam operations and river flow data, to the Fish Passage Center to assist in Water Budget manage. ment.
Date initiated: March 1984

Results/Conclusions: Projact provided information that has been used by the Fish Passage Center as a basis for Water Budget requests and for Water Budget management directed toward improving the survival of juvenile salmon and steelhead migrants. Project has provided information on the migrating characteristics of the various stocks of salmon and steelhead produced in the Col umbia River system. Project continues to provide information for investigating relationships among flows, spill, travel time, smolt condition, and adult production. The 1984-1990 Annual Reports are available; 1992 Annual Report will be available May 1992.

\section{SCHEDULE AND MILESTONES}

1. Fy 1992: 1991 Annual Report available May 1992.

2. Continuing: Project will continue to be funded as part of the smolt Monitoring Program. Contractor will provide annual operational reports and recommend changes as needed to the smolt monitoring schedule and facilities.

Smolt monitoring, as provided under the Fish Spill MOA, is also conducted under project 84-14:

\author{
Smolt Monitoring/Spill - NMFS \\ Project of ficer: V. Jagendorf \\ Obiectives: Provide monitoring \\ of juvenile salmonid out- \\ migrations at John Day and \\ The Dalles Dams, as provided \\ in the Fish spill Memorandum \\ of Agreement (MOA),
}

\section{Date Initiated: 1989}

Results/Conclusions: was conducted at the Dalles Dam for 24 hours/day during the spring and summer out mi grations.
1. FY 1992: Continue gatewell sampling program as per terms of the MOA, or as agreed by the parties.

2. Continuing: Continue gatewell sampling program for the purpose of spill management, pending installation of bypas. 
PROJ ECT

NUMBER

84-14

cont

$83 \cdot 323$

\begin{tabular}{lllllll}
$P$ & $R$ & 0 & E & E & C & T \\
\hline
\end{tabular}

to determine smolt numbers, migration timing, and species composition. This information will be used by the fishery agencies and $T r i b e s$ to manage spill for fish passage under the terms of the MOA.

Smolt Monitoring at the Head of Lower Granite Reservoir and Lower Granite Dam - I DFG

Proiect of ficer: V. Jagendorf

Objectives:

1. Operate the Lewiston and Clearwater traps from March 15 to mid-July as part of the Smolt Monitoring Program for Water Budget, fish collection, and transportation management purposes.

2. Monitor arrival time, rel. ative passage index, and con. dition of juvenile salmon and steelhead into the head of Lower Granite reservoir from snake River tributaries.

3. Determine travel time for hatchery chinook, hatchery steelhead, and wild steel head mi grants from the head of Lower Granite Reservoir to Lower Granite Dam using PITtagged smolts marked at the traps as well as freeze-branded and PIT-tagged smolts passing the traps from upriver sites. monitoring at John Day Dam was conducted during the summer outmigration Ino ad. ditional monitoring over the ongoing Smolt Monitoring Program).

Date initiated: January 1983

Results/Conclusions: The information collected on the migrational timing and condition of juvenile hatchery-produced 2. Continuing: Contractor will provide annual and wild salmon and steel head trout snake reports and recommend changes as needed to the River stocks from 1983 through 1991 has been used for in-season operational decisions relative to Water Budget, facility power operations, and fish collection and transportation programs. The collected information is also being used to investigate the relationships among river flows, travel time, $s$ molt survival and condition, and adult production of salmon and steelhead trout stocks produced in the Snake River

system. The 1983.1990 Annual Reports are available; 1991 Annual Report will be available May 1992.
1. FY 1992: BPA will continue to fund Project 83.323 activities as part of the smolt Monitoring Program. 
PROJ ECT

NUMBER

$87 \cdot 401$

\section{TITLE}

Assessment of 5 molt Condition for Travel Time Analysis - USFWS

Proiect officer: V. Jagendorf

Obiectives: collect information on, smoltification, and pre. valence of disease for marked groups of juvenile salmon and steelhead used by the Fish Passage Center in their travel time studies as part of the 5 molt Monitoring Program. Continue the development of a $s$ molt condition index to monitor fish quality during the seaward migration for use in real-time management and evaluation.

PIT-Tagging of Wild Spring Chinook in Idaho and Oregon

\section{Proiect officer: V. Jagendorf}

Obiectives: Assess the $\mathrm{mi}$.

grational characteristics of

wild/natural parr in selected streams above Lower Granite Dam in Idaho and Oregon during the summer/fall (marking

phase). During the recovery phase the following spring, actual characteristics will be established at PIT-tag recovery sites.

\section{Date initiated: May 1987}

Results/Conclusions: Results show that level of stress, smoltification, and fish health can introduce bias/errors into estimates of smolt survival, and travel time. Measurements of parameters used to quantify the extent of $s$ molt development, level if stress, and pre. valence of disease are neeued to eval uate how these biological factors are in fluencing experimental design assumptions in Columbia River mainstem passage juv enile fish migration studies. The 1987-1989 Annual Reports are available; 1991 Annual Report will be available September 1991.

\section{- Initiated: May 199 !}

Results/Conclusions: Information from wild spring/summer chinook salmon parr PIT-tagged during summer/fall 1991 will be available spring/summer 1992.

\section{SCHEDULE ANO MILESTONES}

FY 1992: BPA will continue to fund Project 87-401activities as part of the Smolt Monitoring Program

\section{Continuing: Contractor will provide annual} reports and recommend changes based on evaluation of results.

1. FY 1992: BPA will continue to fund Project 91.28 activities as part of the Smolt Monitoring Program.

2. Continuing: Contractor will provide annual reports and recommend changes as needed. 
PROJ ECT

NUMBER

91.40

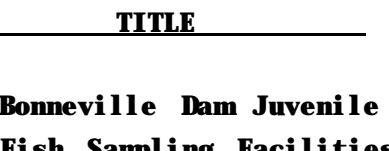

Fish Sampling facilities

Project of ficer: TBA

Objectives: To develop multi. purpose juvenile fish sampling facilities capable of providing information on fish condition and species composition of the general population bypassing the powerhouses, and on the timing, physiology, condition, and growth of PIT-tagged fish.

$\pm$

\section{II. NEW PROJECTS}

\section{PROJECT STATUS}

\section{Date Initiated: FY 1991}

Results/Conclusions: Project 91.13, "PIT-Tag Facilities," is incorporated as part of this project.
SCHEDULE AND MILESTONES

1. Fy 1992: Continue final design drawing for Bonneville Dam I and II improved fish sampling facilities.

2. FY 1993: Initiate construction.

None. 
3,1

ALTERNATI VE CONDUIT SYSTEM FOR IUVENILE FISH

(Test and Evaluate: November 15, 1987; Report January 1988)

$403(d)(2)$

Test and evaluate an alternative conduit system for efficiently conveying juvenile fish from hydroelectric powerhouse intakes to the tail water. This study shall test a design with potential for broad application at dams where turbine intake deflectors are in use or under consideration.

\section{ACTION ITEM ACTIVITY SUMMARY:}

\section{Objectives:}

To test and evaluate alternative conduit systems for bypasing juvenile salmon and steelhead around dams.

\section{Background and Progress to Date:}

As juvenile salmon and steel head migrate downstream past dams, they may be injured by pressurized conduit bypass systems used at most dams. A past study performed by the U.S. Army Corps of Engineers (USACE) and I daho Cooperative Fish and Wi Idlife Research Unit (ICFWRU) demonstrated that an open flume has potential for minimizing injury to fish. BPA contracted wi th these two agencies to design and test different types of flumes to help pass fish safely around dams. The project was completed in March 1988. Results were used in the design of the new smolt bypas system at Little Goose Dam.

PI ans:

Action Item 3.1 has been completed.

Projects:

None, 
4,1

ELLENSBURG TOWN DI VERSI ON DAM FISHWAY AND BYPASS

(Design: October 1987)

(Construction Completed: October 1989)

$803(b)(6) \quad B o n n e v i l l e$ shall fund the design and construction of a low flow vertical slot fishway and replacement of obsolete, inefficient juvenile fish screening/bypass facilities at the Ellensburg Town Diversion Dam.

ACTION ITEM ACTIVITY SUMMARY:

Objectives:

To fund construction of the Ellensburg Town Diversion Dam fish screens.

Background and Progress to Date:

BPA funded the construction of the Ellensburg Town fish screens to improve the outmigration of juvenile salmon and steelhead from the Yakima River system. BPA did not fund the proposed fishway because no fishway presently exists, and the Ellensburg Water Company had a pre-Northwest Power Act obligation to fund fishway construction. Construction of the fish screens was completed in october 1989.

Pl ans:

Action ltem has been completed. 
1. COMPLETED PROJECTS

PROJ ECT

NUMBER

TITLE

$87 \cdot 47$

Ellensburg Screens

Construction - USBR

Project Manaaer: T. Cl une

Obiectives: I mprove fish screen

facility on Ellensburg Water

Company Canal.

11. FY 1991 ONGOING PROJECTS

None.

1II. NEW PROJECTS
PROJECT STATUS

Date Comoleted: October 1989

Results/Conclusions: Construction

of screens has been completed. 
4.2 HABITAT AND PASSAGE I MPROVEMENT PROJECTS

(Consult with Project Sponsors on Need; Complete by 1991)

703(c)(1) [Abstract] BPA shall fund habitat and tributary passage projects as provided in Action Item 4.2. Upon Council approval of system plans provided for in Section 205, System Planning, BPA shall fund habitat and passage restoration or improvement measures in those plans, including those measures identified in the plans that are listed in Appendix A Table: PIanning Inventory of Enhancement Projects.

\section{ACTION ITEM ACTIVITY SUMMARY:}

Objectives:

To consult with project sponsors to determi ne whether projects listed in Action Item 4.2 are needed in the immediate future; to complete them by 1991 if they are needed.

\section{Background and Progress to Date:}

On May 7, 1987, BPA sent a letter to all habitat and tributary passage project sponsors to determi ne whether the listed projects were needed in the immediate future. All project sponsors, except Washington Department of Fisheries (WDF), stated that their listed projects were needed in the immediate future. WDF (June 2, 1987) recommended the following actions:

Subbasin

Yaki ma

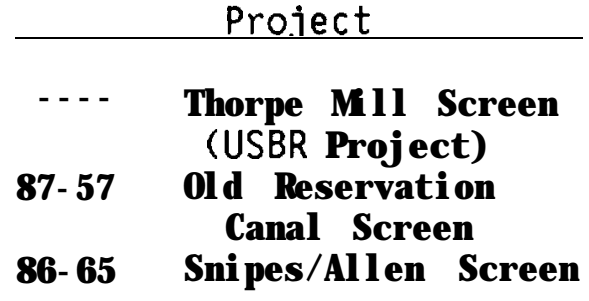

Recommendation

Hold

Del ay

Del ay

A total of _habitat and tributary passage improvement projects are listed in the AIWP, including _ ongoing projects, _ completed projects, one deferred project, and one new project. Due to the large number of projects involved in the i mplementation of Program Measure $703(\mathrm{c})(1)$, the diversity of activities included, and BPA's continuous implementation support of habitat and passage projects, a table format was developed and used to review BPA implementation in the FY 1987 Work PIan. The same table format (Table 5) has been used in the current AI WP, but only for projects that started before FY 1991. Projects that started in FY 1991 and new FY 1992 projects have been described using the same format as is used in the rest of the AI WP, with completed, ongoing, deferred, and new projects described in separate tables. 
Table 5 covers research projects, evaluation projects, and habit at and passage enhancement projects. The last group is listed by subbasin, beginning with the Willamette/ Clackamas River subbasin and proceeding upriver to the Salmon River subbasin. I nformation presented in the Table includes: the project description, current project status, and contract-effective period.

I n FY 1987, BPA developed an Implementation PIan outline for habitat and passage enhancement projects and asked Project Leaders to complete I mplementation PIans in FY 1988. BPA funding in FY 1988 was contingent upon completion of plans for all ongoing and new projects. Plans were completed for ongoing projects funded in FY 1988 .

These habitat and passage enhancement project I mplementation PIans will improve planning and scheduling of i mplementation efforts and will clearly define the projects. The plans will also enable BPA to accurately determine the funding required for completion of a project. Each completed I mplementation PIan contains:

1) background information, such as specific project location, existing conditions, fishery resources, I and use activities, and I i miting factors; 2) enhancement techniques and an implementation schedule; 3 ) expected increase in fish production due to the project; 4) methods for monitoring physical habitat changes resulting from the project; and 5) cost of the project, including total cost and cost by fiscal year. BPA expects projects to be implemented as planned and scheduled in the Implementation PIans.

Plans:

BPA will continue to i mplement the projects listed in Action Item 4.2 of the 1987 Program (if they are needed in the immediate future). BPA will negotiate statements of work for FY 1992 i mplementation of habitat improvements by a number of projects that were originally scheduled for only O\&M activities in FY 1992 (see Council letter and BPA response in Appendix $C$ of the AIWP). The FY 1992 funds reserved by "placeholder" Project 91-10, ISP I mplementation, will be re.-allocated to individual ongoing habitat projects as required to fund the additional habitat work. 
1. COMPLETED PROJECTS

See Table 5 .

11. FY 1991 ONGOING PROJECTS

See below and Table 5 .

PROJ ECT

NUMBER

$91 \cdot 15$
PROIECT STATUS

Expected Start Date: May 1991

Results/Conclusions: Not available at this ti me.
SCHEDULE AND MILESTONES

Fy 1991: BPA determines methods of procurement for developed sow and initiates project estimated completion of project is within 8.10 months from start date.

Objectives: Project will

develop standards and guidelines for the selection of new habitat enhancement projects for BPA i mplementation beginning in

Fy 1992. Methods for determining Iimiting factors to fish pro. duction and for monitoring and evaluating fish and wildlife benefits resulting from stream habitat enhancement or pro. tection projects will also be developed. Other major objectives include:

1. Define basline fish population and riparian habitat data necessary to allow for determination of changes in

these parameters over time as a result of enhancement work

on habitat protection measures. 
PROJ ECT

NUMBER

$91 \cdot 15$

cont.

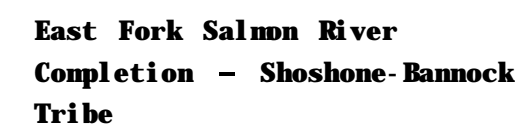

Proiect officer: S. Levy

obiectives: I mprove

habitat for spring chinook.

86.79.1 Fifteenmile Creek -

Phase IV - V - ODFW

Proiect officer: R. St oots

Obiectives: Overall objective

is to increase the production

of wild winter steelhead within

the basin:

1. Reduce lethal summerwater

temperat ures.
Expected Start Date: September 1, 1991 FY 1991: Start project.

Results/Conclusions: None at this time.

Date Initiated: November 1, 1990

FY 1991: Begin implementation

Results/Conclusions: None at this time. FY 1992: I mplement new habitat restoration measures along with maintaining previous projects completed under Contract No, 86.79. 
PROJ ECT

NUMBER

86.79.I 2. Increase summer water flow.

cont. 3. Restore fish habitat di.

versity within the stream.

4. I mprove stream channel

stability.

5. Reduce sediment loading

through restored riparian

vegetation.

1II. NEW PROJECTS

None. 


\section{Table 5: Habitat I mprovement and Passage Enhancement Me asure $703(\mathrm{c})(1)$ \\ Status Report}

PROJECT
NUMBER PO $1 / 2 /$ $T I T L E / O B] E C T I V E$

PROJECT STATUS

\section{RESEARCH PROJECTS}

None

II. EVALUATION AND MONITORING PROJECTS

83.7 RJA Monitoring and Evaluation of Idaho Habitat I mprovement Projects - IDFG

\section{原}

Objective: Evaluate the juvenile chinook and steel head production benefits of habitat and passage i mprovement projects in the Clearwater and Salmon River basins in order to produce the offsite mitigation record for Idaho.
Detailed project accomplishments are $8 / 15 / 83$

Project benefits to date are modest:

barrier removals, followed by in-

stream structures, have had the

largest effect on increasing

anadromous fish production. More

intensive evaluations by this project

have detected some significant

density increases due to structures,

but the majority of differences

were not significant.

Benefits of habitat improvement projects in terms of adult returns and resulting seeding levels will

depend on improved flows and passage conditions. The depressed nature of upriver anadromous stocks has pre.

cluded attainment of full benefit of any habitat project in Idaho. 
PROJ ECT

NUMBER PO $\stackrel{1 /}{-}$ PM

$83 \cdot 7$

cont.

$84 \cdot 11$ RDS

Clackamas/Hood River Habitat Enhancement Program USFS/Mt. Hood NF

Fish Creek Evaluation Subproject

Objective: To evaluate and quantify drainage-wide changes in habitat and smolt production as a result of habitat improvement.
CONTRACT TERM

START PROJECT STATUS

DATE

RENE WAL

Monitoring of control and treatment streams within the Cleat-water and Salmon River drainages will continue in Fy 1991. Project is expected to

be completed in FY 1992.

Monitoring and Evaluation is ongoing in FY 92. 
PROJEUI

NUMBER PO $\stackrel{1 /}{=} \underline{2}$ TI TLE/OB]ECTIVE PROJECT STATUS

\section{PASSAGE AND HABITAT I MPROVEMENT}

\section{Wi Il amette River/Clackamas River Subbasin}

84.11 RDS Clackamas/Hood River Habitat Enhancement - Mt. Hood NF

Collawash River Falls Passage Subproject

objective: Construct a fishway to correct iollawash

Falls passage problems. The falls prevent accees

to potential spawning and rearing habitat.

Improvement: Structure and passage

Habitat: 10 miles

Species: Spring chinook, winter and summer steelhead,

and coho

Benefit: Increase of 55,532 smolts and 2,957 adults.

Collawash River Drainage Habitat I mprovement; Hot springs fork subdrainages subproject

Obiective: Install instream structures to improve spawning habitat and effective cover.

Improvement: Instream structure

Habitat: $\quad 10.6 \mathrm{miles}$

Species: Winter and summer steelhead, spring chinook and coho $s$ al mon

Benefit: 7,249 coho smolts; 2,616 chinook smolts; and 4,229 steel head smolts.
O\&M in FY 92.

O\&M in FY 92. Will negotiate potential implementation projects in FY 92 . 
PROJECT
NUMBER PO $1 / 2 /$

$84 \cdot 11$

cont
Lake Branch/West Fork Hood River I mprovement Subproject

Obiective: I mprove adult/juvenile fish passage and the qual ity of spawning and low-flow rearing habitat.

I mprovement: Instream structure and passage

Habitat: $10.0 \mathrm{miles}$

Species: Summer and winter steelhead, chinook

Benefit: 1,309 chinook smolts; 1,748 steelhead smolts.

Fish/Wash Creek Habitat I mprovement Subproject

Obiective: I mprove spawning and rearing habitat for salmon and steelhead through habitat improvement measures.

Imorovement: Instream structure

Mabitan: $i$ e $s$

species: spring chinook, coho, winter and summer steel head.

Benefit: 1,857 steelhead smolts; 1,317 coho smolts.

Lower Oak Grove Fork Habitat I mprovement Subproject

Objective: I mprove fish rearing and spawning habitat in the lower 3.8 miles of stream.

Improvement: Instream structure

Habitat: 3.8 miles

Species: Winter and summer steel head,

chinook and coho salmon

Benefit: 680 steelhead smolts; 2,536 coho smolts.
CONTRACT TERM

START RENEWAL PROJECT STATUS

DATE DATE

FY 92 activities include $0 \& M$ of previous projects. Will negotiate potential i mplementation projects in FY 92 .

FY 92 activities include O\&M of past projects. Will negotiate potential implemenation projects in FY 92 .

FY 92 activities include $0 \& M$ of past projects. Will negotiate potential implementation projects in FY 92 . 
PROJECT

NUMBER PO $1 /{ }^{2}$

$\underline{2 /}$
TI TLE/OB]ECTIVE

$84 \cdot 11$

cont.

Obiective: Improve adult and juvenile fish passage,

spawning and rearing habitat, and water quality

conditions.

Improvement: Passage and instream structure

Habitat: $120 \mathrm{miles}(30 \mathrm{mi}$ USFS I ands)

Species: Wild winter steelhead

86.124 RDS Little Fall Creek Fish Passage - Facilities Maintenance

Obiective: Provide 0 \& $M$ funding for Fish

Passage facilities.

Improvement: Structure and passage

Habitat: 14 miles

Species: Salmon and steelhead

Benefit: Potential of adults:

$\stackrel{\infty}{N}$

Spring chinook adults: 256

\section{Fifteenmile creek Subbasin}

Objective: Increase wild winter steelhead production to levels which approximate historic maximum run sizes.

Improvement: Passage and instream structure

\section{Habitat: 120 miles}

Species: Wild winter steelhead

Benefit: $11,715 \mathrm{smolts} /$ year

Project completed. O\&M is to be continued under Project No.

tivities include oam of potential implementation projects in FY 92.

A multi-year 0\&M agreement has been $7 / 22 / 86$ negotiated through $9 / 15 / 92$, with FY 89 funding. 


\section{Deschutes River Subbasin}

81.108 RDS Habitat Quality and Anadromous Fish Production Potential on the Warm Springs Indian Reservation - CTWSIR

Obiective: The project consists of three phases:

l. Survey existing and potential fishery resources on the Reservation; II. Identify factors limiting anadromous fish production and design appropriate instream or riparian enhancement measures to correct

Iimiting factors; and III. I mplement measures and evaluate effectiveness.

Species: Summer steelhead and spring chinook.

Beaver Creek Habitat I mprovement Subproject

Objective: Construct instream structures to provide juvenile salmon and steelhead rearing habitat in channelized sections of Beaver Creek. Fence riparian zone and rip-rap banks with juniper.

I mprovement: Instream and riparian

Uabitanti l e $s$

Species: Wild spring chinook.

Benefit: 6,750 spring chinook smolts.

\section{Mill Creek Habitat I mprovement Subproject}

Obiective: construct instream structures to provide juvenile salmon and steelhead rearing habitat in the Potter's Pond section of Mill Creek. Fence riparian zone. I morovement: Instream and riparian

Habitat: $1 \mathrm{mile}$

Species: Wild spring chinook and summer steelhead

Benefit: 1,020 spring chinook and 540 summer steelhead

smolts.
Phase 1: completed in Fy 82.

Phase II: completed in Fy 87.

Phase III: I mplementation of habitat

enhancement measures was completed

in Fy 89. Monitoring of project effectiveness will be completed in Fy 90 with the final evaluation report completed in Fy 91. O\&M of past projects in Fy 92

Instream structures completed in Fy 86 Fencing and juniper rip-rap completed

in Fy 89. O\&M of past projects in Fy 92.

Instream structures completed in FY 87. Fencing completed in Fy 89 .

O\&M of past projects in Fy 92 . 
$81 \cdot 108$

cont.

Shitike Creek Habitat I mprovement Subproject

obiective: Stabilize stream channel, create a low-flow

Instream structures completed in

FY 89, 08M of past projects in

passage channel, develop pool habitat, and provide shading.

Improvement: Instream and riparian.

Babitat: i l e $s$

Species: Wild spring chinook and summer steelhead.

Benefit: 3,139 spring chinook smolts and 2,642

summer steel head smolts.

$84 \cdot 6$

DE

Trout Creek Riparian Enhancement - ODFW

objective: Construct instream and riparian structures

to provide juvenile salmon and steelhead rearing habitat

and adult spawning habitat.

Improvement: Instream and riparian.

Habitat: 90 miles

Species: Steelhead and spring chinook

Benedit: $0 \quad 1500$ adult steelhead.

$88 \cdot 116$

DEJ Trout Creek O\&M

Obiective: To maintain fences and instream structures constructed under Project 84.62. ment structures in Fy 92.
Construction is ongoing and

DATE

BPA will continue funding mainte-

nance of Trout creek habitat improve- 
CONTRACT TERM

PROJECT

$1 / 2 /$

TI TLE/ OB] ECTI VE

PROJECT STATUS

START

RENE WAL

John Dav River Subbasin

84.8 RDS N. Fork John Day River Habitat Enhancement -

$4 / 1 / 84$

$4 / 1 / 92$

USFS/Umatilla NF

\section{Desolation Creek Subproject}

Obiective: Increase the production potential of summe steelhead and spring chinook by improving pool: riffle

ratio, constructing adult salmon resting pools, in.

creasing quality and quantity of spawning habitat, and controlling bank erosion.

Improvement: Instream structure

Habitat: 42 miles

Species: Spring chinook, summer steelhead

Benefit: Spring chinook - 4950 smolts

Summer steelhead -2475 smolts

ज)

Obiective: Increase production of spring chinook through side-channel modification, improve juvenile rearing area, improve bank stabilization, increase adult resting areas, and increase amount of riparian vegetation.

Improvement: Instream structure

Species: spring chinook

Benefit: 5,000 smolts/yr

$\underline{1} / P 0=$ Project officer: RJA/R. Austin, JAB/J. Bauer, DEJ/D. Johnson

2/PM = Project Manager: SML/S. Levy, JGM/J. Marcotte, RDS/R. St oots

Fy 92 activities include 0\&M of previous projects. Will negotiate potential i mplementation projects in FY 92.

FY 92 activities include O\&M of previous projects. Will negotiate potential implementation projects in FY 92. 
$84 \cdot 8$

(cont.)
Wall Creek system Subproject

Obiective: I mprove quality and quantity of juvenile salmonid rearing area and adult spawning area; control bank erosion; increase amount of riparian vegetation. Improvement: Instream st ructures.

Habitat: 7 miles

Species: Summer steel head.

Benefit: 2,274 summer steelhead smolts.

\section{Fivemile Creek Subproject}

Obiective: Increase production of summer steelhead Improvement: Instream structure

Habitat:

Species: Summer Steel head

Benefit: 375 steelhead smolts

Camas Creek system Subproject

obiective: I mprove quality of juvenile saimonid rearing area and adult spawining area: control bank erosion: increase amount of riparian veget ation.

I mprovement: Instream structures.

\section{Habitat: 16.5 miles}

Species: Summer steel head

Benefit: 5,362 summer steelhead smolts
O\&M is included for FY 92, Will negotiate potential implementation projects in Fy 92.
O\&M is included for FY 92. Wi II negotiate potential implementation projects in Fy 92 .

O\&M is included for FY 92. Will negotiate potential implementation projects in Fy 92. 


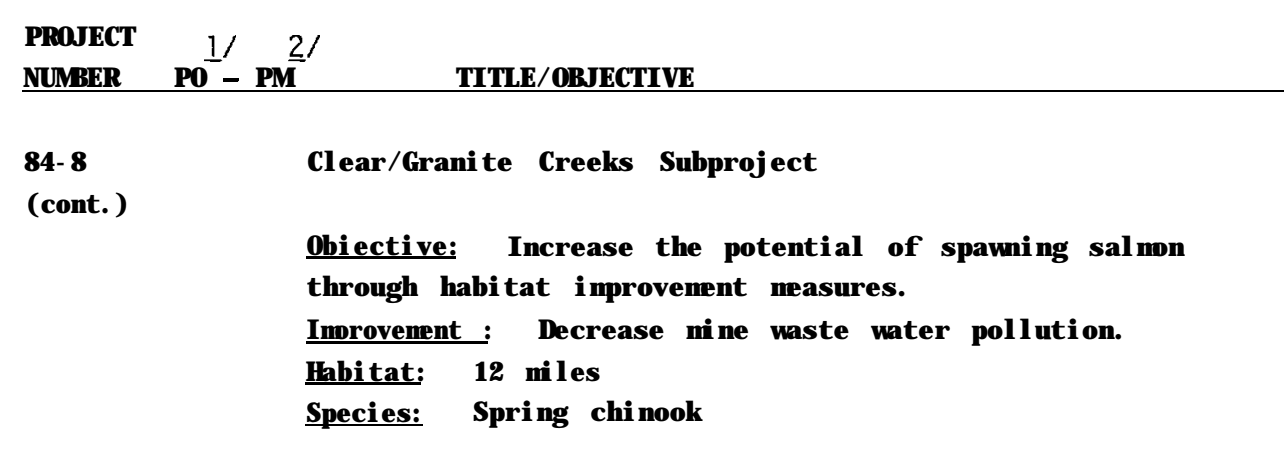

84.21 RDS Mainstem, Middle and North Fork/John Day River - ODFW PROJECT STATUS

Mainstem John Day River Subproject

obiective: Provide additional rearing habitat for juvenile salmon and steel head.

\section{Imorovement: Fencing and instream structure Habitat: 23 miles \\ Species: Spring chinook and Summer steel head \\ Benefit: Steelhead smolt increase - 344,000;}

chinook smolt increase $-371,000$ to 996,000

Middle Fork John Day River Subproject

Objective: Provide additional holding areas for adult chinook and steelhead; improve rearing area for juveniles of both species.

Improvement: Fencing and instream structure Habitat: 30 miles

Species: Spring chinook, summer steelhead

Benefit: Included in benefits for the Mainstem John Day River.
FY 92 activities include O\&M of previous projects. Will negotiate potential implementation projects in FY 92.

O\&M is included for FY 92. Will negotiate potential i mplementation projects in Fy 92.

O\&M is included for FY 92. Wi II negotiate potential implementation projects in Fy 92. 


\begin{tabular}{lll} 
CONTRACT TERM & \\
PROJECT & $1 / 2 / 2$ & START \\
NUMBER & RONEWAL & PROJECT STATUS \\
\hline
\end{tabular}

84.21 North Fork John Day River Subproject, including Fox

(cont.) Creek

Objective: Fox creek - improve steel head spawning and rearing conditions through increasing riparian vegetation, reducing erosion and sedimentation, and increasing pool areas.

Improvement: Fencing and instream structure

Habitat: 42 miles

Species: Spring chinook and steelhead

Benefit: Included in benefits for the Mainstem John

Day River.

North Fork John Day River Subproject, including Camas

Creek

Objectives: Provide additional rearing habitat for

juvenile steelhead.

\&

Improvement: Fencing and instream strucure

Sabitanti I e $s$

Species: Summer steel head

Benefit: Included in benefits

for the Mainstem John Day River.

84-22 RDS Middle Fork and Tributaries, John Day RiverUSFS/Malheur NF

objective: Increase the quantity, quality, and diversity in Fy 92.

FY 92 activities include $0 \& M$ of previous projects. Will negotiate potential implementation projects of pool habitat for juvenile steelhead and chinook

$s$ al mon.

I mprovement: Instream structure

Species: Chinook and Steelhead

Babitat: i l e $s$
FY 92 activities include $0 \& M$ of previous projects. Will negotiate potential implementation projects i $\mathrm{FY} 92$.

Will negotiate potential

i mplementation projects in Fy 92.

$1 / P 0=$ Project officer: RJA/R. Austin, JAB/J. Bauer, DEJ/D. Johnson

$\underline{2} / P M=\operatorname{Project}$ Manager: SML/S. Levy, JGM/J. Marcotte, RDS/R. Stoots 


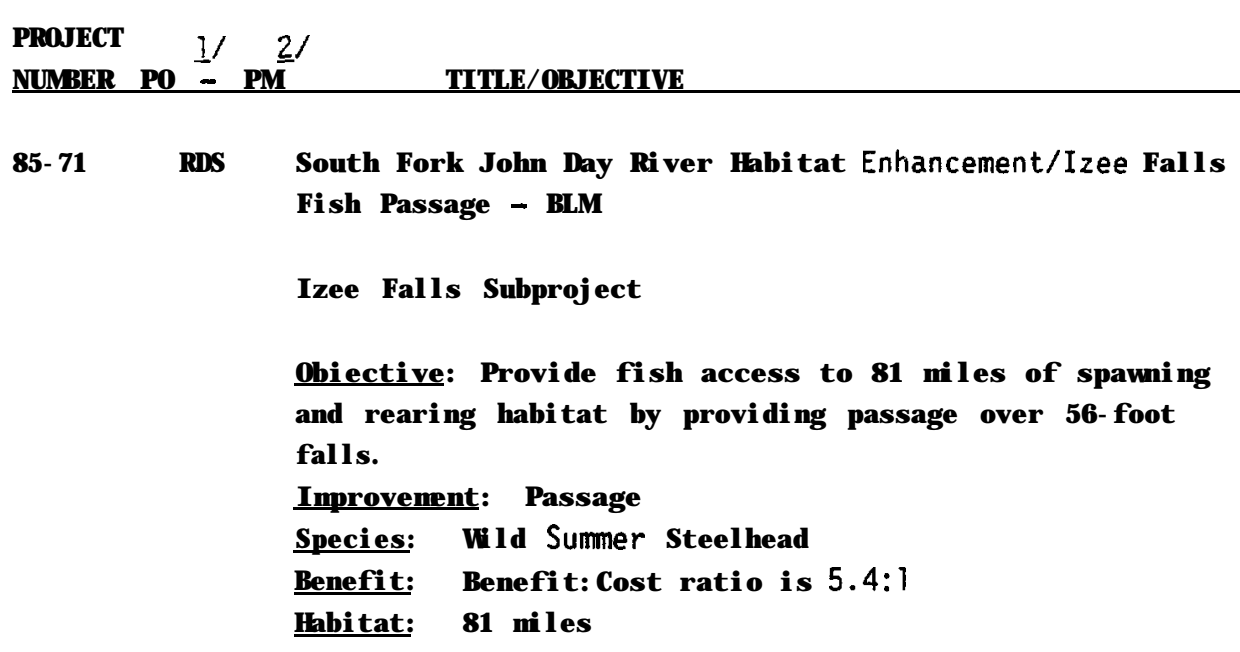

\section{Umatilla River Subbasin}

Construction of right bank ladder and trap completed winter-fall 1988. Operational shake-out period con-

tinues. Construction of left bank facilities completed July 1988.

operational shake-out period for left bank continues. Project-specific monitoring and evaluations began FY 1990 .

\section{$5 / 1 / 84 \quad 08 M$ is}

ongoing 


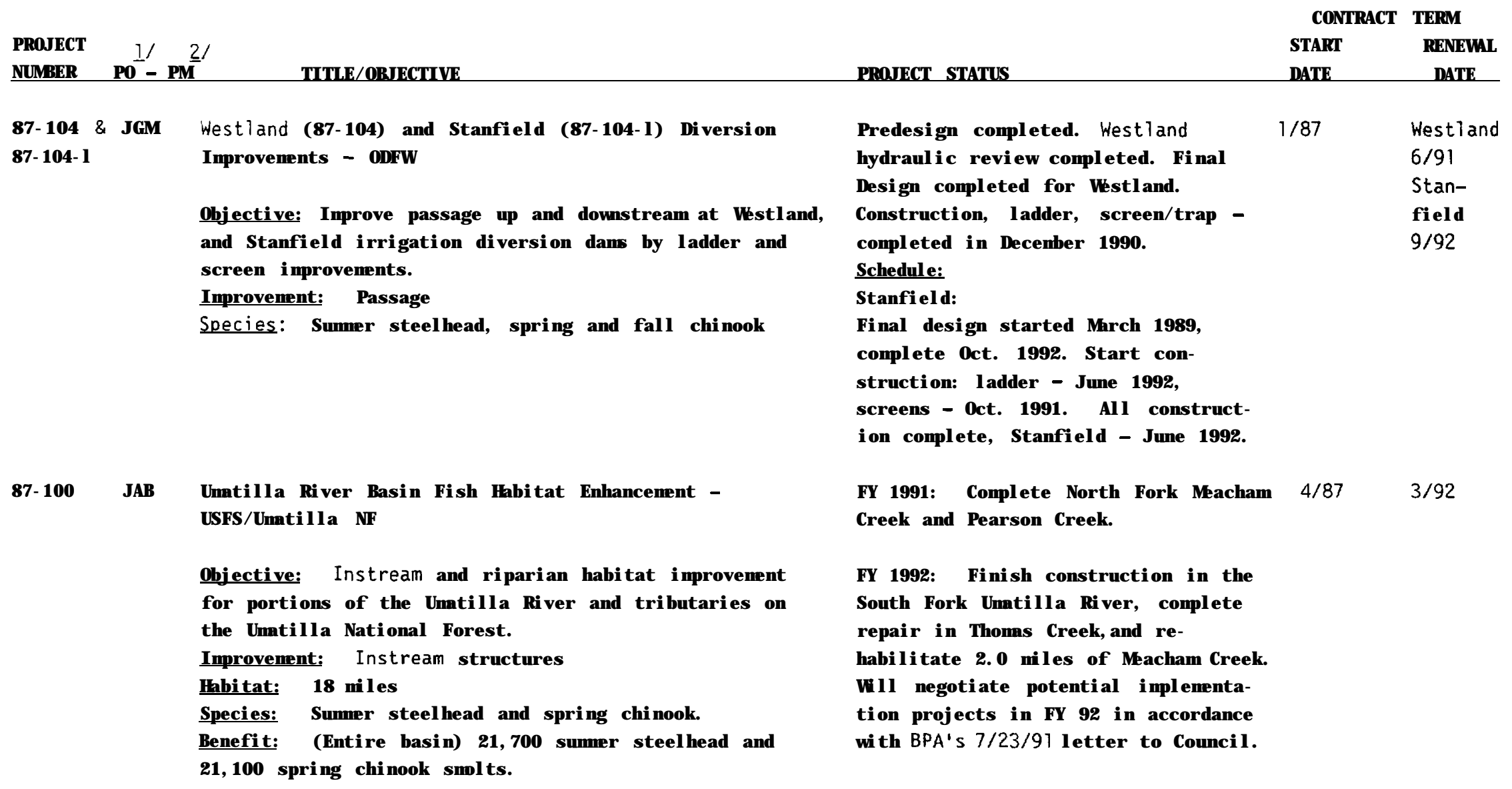


PROJECT
NUMBER PO $\stackrel{1 /}{-}{ }^{2 /}$

$87 \cdot 100 \cdot 1 \quad J A B$

Umatilla River Basin Fish Habitat Enhancement - CTUIR

Obiective: Instream and riparian habitat improvement for portions of the Umatilla River and tributaries on the Umatilla Reservation.

Improvement: Fencing, riparian revegation, instream structures

Habitat: 18 miles

Species: Summer steelhead and spring chinook.

Benefit: See Project 87.100.

87.100.2 JAB Umatilla River Basin Fish Habitat Enhancement - ODFW

Obiectives: Instream and riparian habitat improvement for portions of the Umatilla River and tributaries on privately-owned I and.
Improvement: Fencing, riparian revegation, instream structures

Habitat: 18 miles

Species: Summer steel head.

Benefit: See Project $87 \cdot 100$

88.22 JGM Umatilla River Basin Trap and Haul - ODFW

Obiective: To provide for passage of adults and smolts under low-flow river conditions

I mprovement: Passage

Species: Summer steelhead, spring and fall chinook
PROJECT STATUS

START

FY 1991: Begin construction at

$7 / 87$ DATE

Squaw Creek, continue on Meacham

Creek and Umatilla River.

FY 1992: Complete construction at

squaw Creek, and Meacham Creek.

FY 1991: Complete work at East Birch

Creek, continue at Meacham Creek, and begin work at West Birch Creek.

FY 1992: Complete work at Meacham Creek, continue at West Birch Creek, and start at North Fork Meacham Creek.

Design and acquisition of equipment

(trucks, trailers, etc.)

completed February 1989. Some

equipment modifications to be made

FY 91. Trap at Three Mile Dam right

bank ladder operational - Nov. 1987. Westland smolt trap operational -

June 1990. Trap and haul program operational - May 1989. Continue to conduct program, conduct shake-out at facilities and refine operational criteria, ODFW and CTUIR are funded by BPA to operate trap and haul program. 
PROJECT
NUMBER PO $1 / 2 /$

$89 \cdot 24 \cdot 1$

Passage Facility Evaluation and URB Adult Fish Monitoring

Obiectives: Evaluate loss of juvenile fish due to passage through or over WEID Canal screens. Monitor passage of adult salmon and steelhead at Three Mile Da m.

Species: Summer steelhead, spring and fall chinook

87.416 \& JGM Cold Springs (87.416.1) and Maxwell (87.416) Diversion $87 \cdot 416 \cdot 1$

I mprovement - USBR

Obiectives: I mprove passage up and downstream at Cold Springs and Maxwell diversions. I mprovements include fishways and canal screens.

I morovement: Passage

Species: Summer steelhead, spring and fall chinook.

87.104.2 J GM Westland Non-Fish I mprovements

Obiectives: To install i mprovements on Westland irrigation system that will allow fish passage facilities to operate as intended.

I morovement: Passage

Species: Steelhead and chinook.
All construction complete. USBR turned projects over from construction to O\&M in April 1990. BPA is funding O\&M under an O\&M contract with USBR. The contract term is indefinite.
$7 / 87$ $0 \& M$ is ongoing

Contract in place with Westland

completed June 1990 . Final design completed in september 1990.

Construction to be completed by December 1991. 
PROJECT

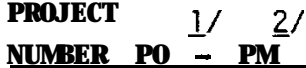

TI TLE / OB]ECTIVE

START

DATE

Grande Ronde River Subbasin

84.9 RDS Grande Ronde Habitat Improvement Project -

USF / Wal I owa. Whi t man NF

Upper Grande Ronde Basin Subproject

Obiective: Improve spawning and rearing habitat in the Upper Grande Ronde River.

Improvement: Instream structures

Habitat: 53 miles

Upper North Fork John Day Basin Subproject

Obiective: Improve spawning and rearing habitat

in the North Fork John Day River

Habitat: 49 miles

Species: Wild spring chinook and steelhead

Lower Grande Ronde Basin Subproject

Obiective: Improve spawning and rearing habitat in the Lower Grande Ronde River.

Habitat: $\quad 30$ miles

species: spring chinook and summer steel head
FY 92 activities include $0 \& M$ of previous projects. Will negotiate potential implementation projects for FY 92.

Fy 92 activities include $0 \& M$ of previous projects. Will negotiate potential implementation projects for FY 92.

FY 92 activities include 08M of previous projects. Will negotiate potential implementation projects for FY 92. 
PROJ ECT

NUMBER $P O^{1 /}-P M^{2 /}$ TI TLE / OBJ ECTI VE

PROJECT STATUS DATE
Upper Grande Ronde Subbasin Subproject

Obiective: Improve the quality and quantity of spawning and rearing habitat for salmon and steelhead through habitat improvement activities.

Joseph Creek Subbasin Subproject

Obiective: I mprove the quality and quantity of spawning and rearing habitat for steel head through habitat

improvement activities.

Yaki ma River Subbasin

86.75 SML Little Naches River Passage - USFS/ Wenatchee NF

Obiective: Construct fish passage facility to correct passage problems resulting from salmon falls.

Rehabilitate flood-damaged reach below falls to provide an adequate passage corridor to the fish passage facility.

Emprovement:a $g e$, instream channel modification, and riparian revegetation

Habitat: 18 to 24 miles, depending on species

Species: Spring chinook, coho, and steelhead

Benefit:

$\begin{array}{ll}\text { Species } & \# \text { Smolts } \\ \text { Spring chinook } & 30,300 \\ \text { Coho } & 39,600\end{array}$

coho

6,500
Fy 92 activities include 0\&M of previous projects. Will negotiate potential implementation projects for FY 92.

FY 92 activities include 0\&M of previous projects. Will negotiate potential implementation projects for FY 92.

Construction of fishway and channel rehabilitation completed fall 1987. BPA will continue to fund operation Late Spring 


\section{Clearwater River Subbasin}

84.5 SML South Fork Clearwater River - USFS

Red River Subproject

Obiective: Increase the quantity and improve the quality of spawning and rearing habitat for anadromous fish.

Improvement: Instream structure

Habitat: Approximately 20 miles

Species: Spring chinook

Benefit: Benefit: Cost ratio is $15: 1$

Crooked River Subproject

Obiective: To increase natural smolt production potential of salmon and steelhead.

Improvement: Structures

Habitat: 17 miles

Species: Chinook and steelhead

Benefit: Benefit: Cost ratio is 6.22:1

84.6 SML Clearwater River Habitat Enhancement I mprovements USF / Cl earwater NF

Lo10 Creek Subproject

Obiective: Increase the quantity and improve the quality of spawing and rearing habitat for anadromous fish.

Improvement: Instream structure

Habitat: 12 miles

Species: Spring chinook and steelhead

Benefit: Benefit: Cost ratio is $40: 1$
Completion scheduled for 1991. O\&M agreement will be required beyond 1991 to protect investments. USF has requested additional funding to add new projects. Final report will summarize project completion.

Completion scheduled for 1991.

Project has been funded to comple. tion with FY 1987 funds. Evalua.

ti on and O\&M scheduled for 1988.1991.

FY 91: Completed. 
Objective: Remove rock barriers to correct passage problems resulting from basalt falls and associated highvelocity chutes which prevent access to spawning and rearing habitat above the site.

Improvement: Instream structure and blasting Habitat: 10 miles

Species: Steel head and chinook

Benefit: 24,000 chinook and 12,500 steelhead smolts

Crooked Fork Subproject

Project completed.

Obiective: Remove rock barriers to correct passage problems resulting from rock chutes and waterfalls which prevent access to spawning and rearing habitat above the site.

Improvement: Instream structure Habitat: $\quad 5.65$ miles

Species: Spring chinook and summer steelhead

Benefit: 36,000 chinook and 21,000 steelhead smolts

Sal mon River Subbasin

84.23 SML Camas Creek, Idaho - USFS/Salmon NF

Obiective: I mprove riparian conditions to increase salmon and steelhead spawning and rearing potential. Imorovement: Fencing and riparian revegetation Mabitat: $i$ e $s$ Species: Spring chinook and steelhead $\frac{\text { Benefit: }}{\text { Steelhead }} \quad \frac{\text { Smolt }}{4,586} \quad \frac{\text { Adults }}{76}$ Chinook $24,570 \quad 128$ 


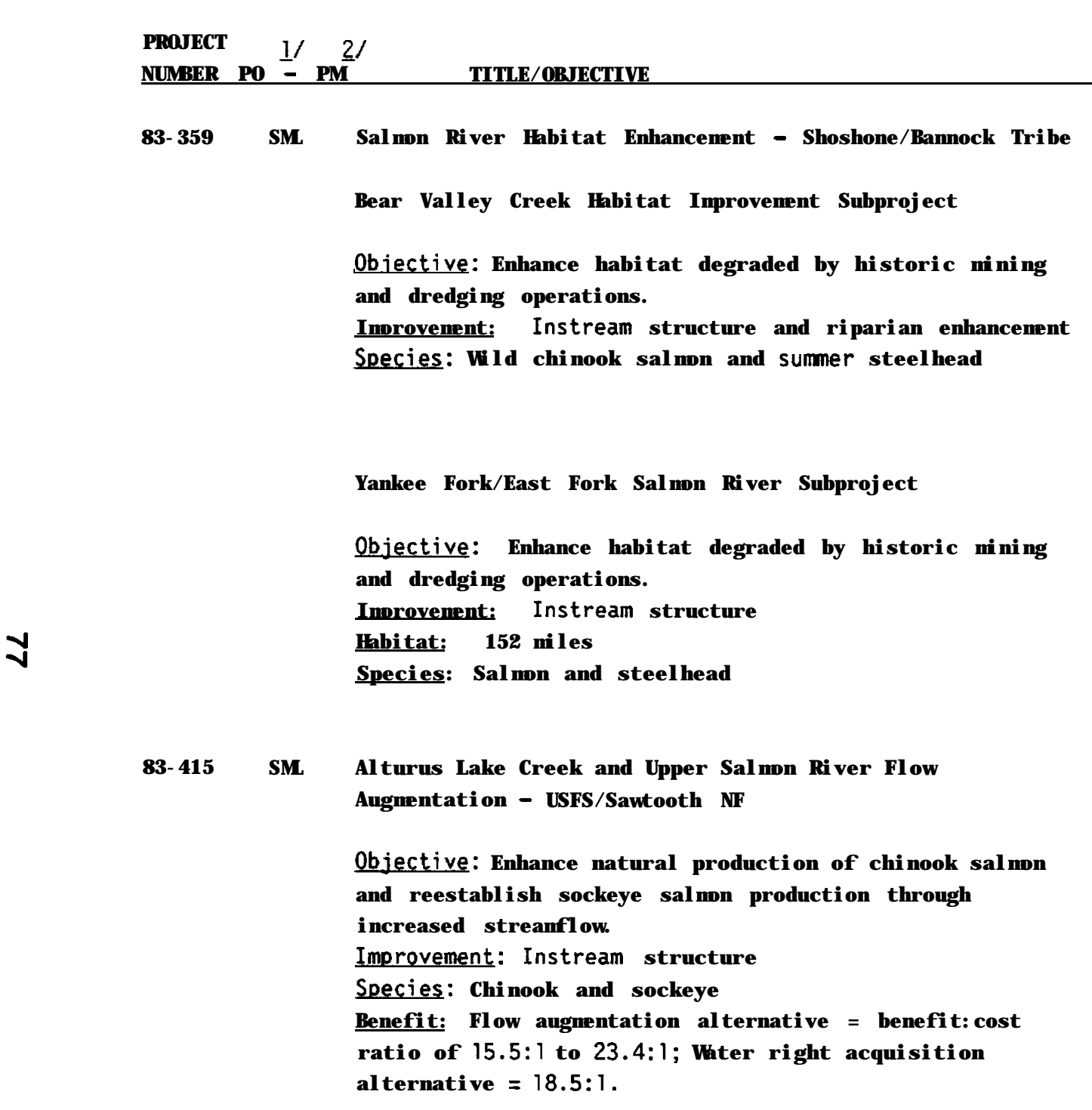

CONTRACT TERM START RENEWAL PROIECT STATUS

DATE DATE

Water rights will be acquired

with full flow available for

fish passage in Alturas Lake Creek during Spring 1992. Increased flows will open up not only passage to Alturas Lake, but spawning gravels as well.

Project construction was completed in Fy 1988. Monitoring will con.

East Fork construction to begin in Funding is insufficient to accomplish all project measures as Construction began in 1987 and was completed for Yankee Fork in Fy 1988. O\&M and monitoring will continue in 1991 and beyond. 


\begin{tabular}{|c|c|c|c|c|c|}
\hline $\begin{array}{l}\text { PROJ ECT } \\
\text { NUMBER }\end{array}$ & $\mathrm{PO}^{\underline{1}}-\mathrm{PM}$ & $T I T L E / O B|E C T| V E$ & PROJECT STATUS & $\begin{array}{l}\text { START } \\
\text { DATE } \\
\end{array}$ & $\begin{array}{l}\text { RE NE WAL } \\
\text { DATE }\end{array}$ \\
\hline $84 \cdot 24$ & SML & $\begin{array}{l}\text { Marsh/EIk/Valley/Upper Salmon River, Idaho - } \\
\text { USFS/Region } 4 \\
\text { Obiective: Identify specific reaches of the Upper Salmon } \\
\text { River, Marsh and Elk creeks where habitat improvements } \\
\text { could Iead to increased salmon and steelhead habitat; } \\
\text { recommend, for future implementation, measures to improve } \\
\text { habitat (e.g., fencing, streambank stabilization and } \\
\text { instream structures). Develop a cost-sharing agreement } \\
\text { (BPA/USFS) for implementation. } \\
\text { Improvement: Instream structure } \\
\text { Habitat: } 150 \text { miles } \\
\text { Species: Steel head. Sprina and summer chinook }\end{array}$ & $\begin{array}{l}\text { PIan/inventory phase has been } \\
\text { completed. Construction began } \\
\text { in 1987. Elk and Lower Bear Valley } \\
\text { creeks were given high priority for } \\
\text { completion. USFs completed an } \\
\text { implementation plan early in Fy } 1988 \\
\text { for completion of all projects. } \\
\text { Construction proceeding on Lower } \\
\text { Bear Valley Creek, Elk Creek and } \\
\text { Upper Salmon River projects. }\end{array}$ & $6 / 29 / 84$ & $4 / 30 / 92$ \\
\hline
\end{tabular}




\subsection{ROZA DAM FISH PASSAGE FACILITIES}

(Juvenile Facilities Completion: March 1, 1987)

(Adult Facilities Completion: March 1, 1988)

803(b)(2) [Abstract] BPA shall fund the U.S. Bureau of Reclamation (USBR) to renovate and repair adult and juvenile fish passage facilities at Roza Dam.

ACTI ON ITEM ACTIVITY SUMMARY:

Objectives:

To fund the USBR to renovate and repair adult and juvenile fish passage facilities at Roza Dam.

Background and Progress to Date:

The USBR owns Roza Dam; fish passage facilities have been constructed through Congressional appropriations. The project is one of 20 such passage i mprovement projects in the Yaki ma River Basin. Fish screen and ladder i mprovements were required to protect juvenile fish from being lost in irrigation canals and to enable adult salmon and steelhead to migrate upstream to spawn. The project now provides adequate upstream and downstream fish passage, including adequate passage during periods of reservoir drawdown.

USBR began screen construction in December 1985; facilities and ladder modification construction bids were opened in August 1986. Construction of the facilities was completed in Fy 1989.

Plans:

Action Item has been completed.

Projects:

No BPA. funded projects. 
4.4 PROSSER DAM FISH PASSAGE FACILITIES

(Juvenile Facilities Completion: March 1, 1987)

(Adult Facilities Completion: December 1, 1987)

803(b) (3) [Abstract] BPA shall provide funds to the USBR for construction of i mprove. ments and additions to Prosser Dam necessary to provide safe, efficient, and timely passage of adult and juvenile fish.

ACTION ITEM ACTIVITY SUMMARY:

Objectives:

Provide funds to the USBR for construction of Prosser Dam improve. ments and additions necessary to provide safe, efficient, and timely passage of adult and juvenile fish.

Backaround and Proaress to Date:

The USBR owns Prosser Dam; fish passage facilities have been constructed through congressional appropriations. The project is one of 20 such passage improvement projects in the Yakima River Basin.

Fish screen and ladder improvements were required to protect juvenile fish adequately from being lost in irrigation canals and to enable adult fish to migrate upstream to spawn.

USBR began screen construction in May 1986. Right bank Iadder was completed in May 1986. Left and center ladders were completed in September 1989.

Plans:

Action ltem has been completed.

Projects:

No BPA.funded projects. 
4.5 YAKI MA RIVER FISH PASSAGE I MPROVEMENTS

(Completion of Elements in Table 3 of 803 (b)(5): December 1, 1988)

(Post-Construction Evaluations)

803(b) (5) Upon approval by the Council, BPA shall fund the design and construction of the improvements listed in Table 2. All fish screening facilities shall meet current screening design st andards.

ACTION ITEM ACTIVITY SUMMARY:

Objectives:

To construct Yaki ma River fish passage improvements.

Background and Progress to Date:

A network of irrigation canals diverts water from the Yakima and Naches rivers for use by various agricultural interests in the Yakima River Basin of Central Washington. Juvenile salmon and steel head often stray into these canals during their outmigration to the sea. The BPA, USBR, Bureau of Indian Affairs (BIA), and Washington state are constructing fish screens to direct the young salmon and steelhead back to the Yakima and Naches rivers.

The Yakima Project entities will fund the construction of fish ladders at various projects to facilitate the normal upstream migration of adult salmon and steelhead.

PI ans:

BPA plans to fund construction through to completion and to evaluate projects as they are completed.

See project summaries on following table. 


\section{COMPLETED PROJECTS}

None.

\section{FY 1991 ONGOING PROJECTS}

PROJECT

NUMBER TITLE

$85 \cdot 62$ Passage I mprovement

Evaluations - BPNL

Proiect Manaaer: $T, \quad \mathrm{Cl}$ une

Obiectives: Evaluate effectiveness of passage

i mprovement projects.

Phase 2 Screen Design and Construction - USBR

Proiect Manaaer: T. Clune

Obiectives: Predesign/NEPA of 63 fish screen facilities throughout the Yakima Basin.

Project 88.111, Stevens/Naches/

Selah Screens, and Project

86.65, Snipes/Allen Screens,

have been combined with Project

89.90.

\section{PROJECT STATUS}

Date initiated: March 1985

Results/Conclusions: Evaluation is ongoing; results published in BPA annual reports.

Date Initiated: July 1989

Results/Conclusions: Preliminary design Fy 1991: Complete design and begin construction of of Group 1 complete.
SCHEDULE AND MILESTONES

Continuing: Evaluation will continue as projects are completed and go on line.
FY 1990: Begin predesign and NEPA. 
PROJ ECT

NUMBER

$91 \cdot 57$

Yaki ma Phase 2 Screen

Fabrication - WD

Proiect Manaaer: T, Cl une

Obiectives: Fabrication of

Phase 2 screen $d r u m$ assemblies and associated mechanical

components.

\section{II. NEW PROJECTS}

92-15 Dryden Screens Design and Construction

$\stackrel{\infty}{心}$

Proiect Manaaers: T. Cl une

Obiectives: Conduct environ

mental analysis, design, and

construct fish screening

facilities at the Dryden

Canal. These facilities will

protect juvenile spring and

summer chinook from being

trapped in the canal.
Expected Start Date: May 1991

Results/Conclusions: None at this time.

FY 1992: Initiate and complete NEPA compliance and facility design.

FY 1993: Construct facility.
FY 1991: Begin fabrication of Phase 2 screen assembli es.

FY 1992: Continue fabrication for Group 2 through 5 projects. 
4.6 WATER EXCHANGE FOR UMATILLA RIVER

(Support Beginning Spring 1987)

(Report Evaluations: Annually)

703(a)(17) [Abstract] BPA shall provide power or reimbursement for power costs to USBR pumping plants designed to exchange Columbia River water for Umatilla River water. The USBR must obtain consent from all affected water users and regulators and provide assurance to the council that water exchanged to augment streamflows will be used to meet annual flow objectives established by the ODFW and the CTUIR. The Oregon Water Resources Department (OWRD) will certify annually to the council that the exchanged water will improve instream flows and will benefit fish. The USBR shall fund state and tribal fish and wild ife agency monitoring and evaluation studies to determine the biological effectiveness of this measure.

\section{ACTION ITEM ACTIVITY SUMMARY:}

Objectives:

To support instream flow enhancement efforts, which will increase Umatilla anadromous fish production by improving passage and rearing conditions.

\section{Backsround and Progress to Date:}

Federal authorizing legislation prepared by project sponsors was approved in fall 1988. The Council amended the Program to provide for BPA funding of power costs associated with interim pumping. USBR will handle operation and maintenance, capital and evaluation activities.

Because the original Program Ianguage did not include interim pumping and because USBR pumping plants are still in the planning/design stage, no water exchanges under this Action Item took place until Spring 1989. Through passage-assistance projects (Projects 87.409 and 88-50) under Action Item 4,2, BPA had provided for pumping power to operate existing West Extension Irrigation District (WEID) pumps to increase flows below Three Mile Dam during spring and fall 1987 and during spring and fall 1988. Under Project 89.27, BPA has reimbursed USBR for power costs for interim pumping conducted each spring and fall, and will continue to do so until phase $I$ of the USBR's Umatilla Basin Project is in place.

In June 1989, the USBR, wi th assistance from BPA, OWRD, ODFW, Tribes, and the Basin steering Committee, finalized a basin work plan that included the schedule for interim pumping and project completion and defined the scope of monitoring and evaluation activities. BPA and USBR entered into an Interim Pumping Agreement in 1990 to provide for the transfer of funds for power costs associated wi th interim pumping. The first interim pumping under this Program measure took place in spring 1989. In spring 1990, USBR and BPA began planning for power needs for the USBR's Umatilla Basin Project. 
Construction of Phase I began in April 1991 and completion is scheduled for March 1992.

During FY 1991, discussions began regarding use of Furnish Canal to augment diversions into Cold springs Reservoir. Improvements involve installing pipes or otherwi se improving waterways and laterals from Furnish to Feed Canals. Cold springs Reservoir could be filled more quickly, allowing diversions to be delayed in the fall or shut off early in the spring when fish are migrating. Up to 40.50 cfs could be left in the river for about 29 miles. This strategy could supplement about 8000 acre feet total each year. Funding would be a joint effort of USBR and BPA. Costs are under $\$ 200,000$ capital and $\$ 40,000$ annually in delivery charges ( $\$ 5$ per acre foot). A possible alternative is early implementation of part of Phase II. This project is considered part of Project 89.27.

\section{Plans:}

Continue to fund interim pumping until permanent project is in place, Continue planning for power arrangements for the permanent project. 
1. COMPLETED PROJECTS

None.

11. FY 1991 ONGOING PROJECTS

PROJ ECT

NUMBER

$89 \cdot 27$

Provide Power for USBR

Columbia River Pumps (also

Interim Flow Enhancement)

Proiect officer: J, Marcotte

Objectives: Enhance instream

flows in the Umatilla River by

exchanging Columbia River water

for Umatilla River water.
PROIECT STATUS

Date Initiated: FY 1989 system facilities have been used to provide up to 50 cfs additional water below Three Mile Dam during spring and fall periods. No analysis of biological benefits has been undertaken.

III. NEW PROJECTS

None.

SCHEDULE AND MILESTONES

1. FY 1992: Provide power to Phase I - WEID pumps. Col umbi a River pumps. 
4.6.1 EVALUATE NON. STRUCTURAL WATER MEASURES IN UMATILLA BASIN (Develop Workplan, Report to Council in April 1989)

703(a)(17) [Abstract] BPA, USBR, Council, Oregon Water Resources Department, and other interested parties shall jointly prepare a workplan for an evaluation of non-structural alternatives that may benefit fish and hydropower generation, and whether the combined benefits of such measures can be quantified.

ACTI ON ITEM ACTIVITY SUMMARY:

Objectives:

I dentify and evaluate al ternative means of providing enhanced plans, other than pumping/exchange projects.

Background and Progress to Date:

This action item has been subsumed by the USBR "Section 213" study, mandated by Public Law 100.557. Section 213 instructs USBR to review Umatilla Project operations to identify ways to further mitigate fishery losses. This study encompasses so-called "non-structural" measures in the Program, such as contracts, conservation, reservoir storage allocation, water deliveries, water rights, and water lease and purchase. USBR completed review of the report, finalized it and submitted it to congress in late 1989.

Plans:

USBR to be prepared to follow up on any recommendations congress may direct.

Projects

None. 
4.14,1 TEMPORARY IOHN DAY ACCLI MATI ON FACILI TY

(Upon Council Approval, Complete Construction)

703(f)(2)(B) Upon the Council's approval of the plan, Bonneville shall fund design, construction, and evaluation of the temporary facilities.

ACTI ON ITEM ACTIVITY SUMMARY:

Objectives:

To build and test the effectiveness of acclimation ponds for upriver bright fall chinook salmon from John Day Mitigation Facilities.

Background and Progress to Date:

Acclimation facilities reduce the transportation stress of upriver bright fall chinook transported from John Day Mitigation facilities for release above John Day Dam.

During the first 2 years of the Fish and Wildlife Program, disagreements among affected parties over the location of the acclimation ponds made it difficult for BPA to implement this Measure. When the Council amended the Program in 1984, it provided for: (1) an agency and Tribal plan to be approved before any construction; and (2) an evaluation of temporary acclimation ponds.

In FY 1986, BPA initiated a site survey of 10 candidate acclimation facility sites (Project 86-82) to assist the agencies and Tribes in developing their plan. The joint agency-Tribal work group and the Council have been provided the completion report for the site study completed under Project 86.82. They have selected Ringold Springs as the final site to be used for acclimation.

Plans:

BPA plans to fund the design, construction, and eval uation of the John Day Temporary Acclimation ponds, once the Fish and Wildlife agencies and Tribes have developed the acclimation pond $p l a n$ and the plan has been approved by the Council. BPA removed Project 89.16, Temporary John Day Acclimation Facility, from the FY 1990 and 1991 Al WP and has not included it in the FY 1992 AI WP. 


\section{COMPLETED PROJECTS}

None.

11. FY 1991 ONGOING PROJECTS

PROJ ECT

NUMBER TI TLE

83.313 Pen Rearing of Upriver Fal Chinook Salmon - USFWS

Proiect of ficer: A. Ruger

Obiectives: To evaluate the effectiveness of rearing Upriver Bright Fall Chinook (URBFC) salmon in net pens.
PROIECT STATUS

Date initiated: FY 1983

Results/Conclusions: URBFC salmon can effectively be reared in Columbia River backwaters with net pens, but the actual evaluation of ocean and freshwater contribution and escapement has yet to be completed.
SCHEDULE AND MILESTONES

1. Continuing: Contractor will collect and analyze adult return data: BPA will publish preliminary results in the Annual Report

2. 1991: Contractor will collect and analyze adult return data, and prepare Final Report. BPA will publish final Report.

III. NEW PROJECTS

None. 
4.15.1 DESIGN AND CONSTRUCTION OF YAKI MA HATCHERY

(Upon Council Approval, Fund Beginning in FY 1988)

803(d) [Abstract] BPA shall fund the design and construction of a hatchery for salmon and steelhead enhancement in the Yakima River Basin and el sewhere as described in Section $503(\mathrm{c})(2), 703(\mathrm{f})(3)$, and $803(g)(3)$.

\section{ACTI ON ITEM ACTIVITY SUMMARY:}

\section{Objectives:}

To construct a hatchery to protect wild stocks and to enhance depressed stocks by using hatchery-reared fish to reseed underutilized habitat.

\section{Background and Progress to Date:}

BPA will fund the design, construction, operation, and maintenance of the Yakima outplanting facility. The facility will enhance the fishery for the Yakima Indian Nation and for other harvesters by supplementing natural runs. In November 1987, the Council completed the hatchery master plan, and BPA began predesign in November 1987. Predesign was completed in April 1990. Final design will be completed by October 1992.

BPA will also fund several other related studies, including a study to determine the feasibility of establishing anadromous fish runs above Cle Elum Dam (Project 86.45). The results of this project will directly influence the size and production profile of the Yakima outplanting facility. Another study (Project 87-136) will determine the applicability of acclimating fall chinook salmon in irrigation canals prior to release. Additional studies will be initiated when defined by the Hatchery experimental design task team. The experimental design team, a component of the Yakima Hatchery Technical Work Group (TWG), will develop objectives for the supplementation program and the associated monitoring and evaluation program. Projects will be identified by the TWG and implemented to answer questions resulting from the experimental design. All projects are integral to the overall experimental/supplementation program and should not be regarded as separate or distinct studies.

Plans:

1. National Environmental Policy Act (NEPA) compliance for hatchery construction was completed in April 1990. An Els will be conducted on operational and siting issues. Completion expected October 1992. 
2. BPA will fund design, construction, operation, and maintenance of the hatchery:

$$
\begin{aligned}
& \text { Predesign: } 11 / 87-3 / 90 \\
& \text { Final design: } 8 / 90-10 / 92 \\
& \text { Construction: } 11 / 92-12 / 97 \\
& 0 \& M \text { Begin } 12 / 92 \text { and continue }
\end{aligned}
$$

3. Facility expected to be partially operational in Fy 1993. 
1. COMPLETED PROJECTS

\section{PROJECT}

NUMBER

$89 \cdot 100$

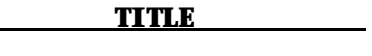

Technical Writer - BPNL

Proiect Manaaer: T. Cl une

Objectives: Technical assistance for experimental design and NEPA compliance for hat.

chery predesign report.

11. FY 1991 ONGOING PROJECTS

\section{PROJ ECT}

OR TASK

$\mathscr{V}$

\section{PROJECT STATUS}

Date initiated: October 1986

Results/Conclusions: Eggs were

collected in July 1987/90. Fingerlings 2. Continuing: Evaluate survival of tagged being reared. Tests indicate all

fish are IHN-negative. Test groups were released in and below Lake $\mathrm{Cle}$

El um i n May 1990. Preli mi nary data

being collected at Prosser and McNary

Dams. Sockeye have been found to

migrate out of the lake.
SCHEDULE AND MILESTONES CWT and PIT tags.

fish. Continue through 1994.

3. Develop juvenile bypass system.

4. Determine the mechanism to trigger the emigration response.
1. 1992: Release 1990 brood year with 
PROJ ECT

OR TASK

NUMBER

$88 \cdot 115$

$88 \cdot 120$

TITLE

Yaki ma/KI ickitat Production

Facilities Design and

Construction

\section{Proiect Manaaer: T. Cl une}

obiectives: Continue design for Yakima/Klickitat Production Facilities.

Yakima and KI ickitat Basin Artificial and Natural Production Enhancement Program - YIN

Proiect Manaaer: T. Clune

Proiect Bioloaist: T, Vogel

Obiectives: Provide for participation of YIN, WDF, and WDW in development of a natural and artificial pro. duction program.

Yaki ma Hatchery CoordinationRoza Irrigation District.

Proiect Manaaer: T. Cl une

Obiectives: Provide for technical assistance from Roza Irrigation District on hatchery project.
PROJECT STATUS

Date Initiated: FY 1988

Results/Conclusions: Completed predesign Fy 1992: Continue final design and conduct Els. report April 1990. Presented report to

Council, Initiated Els December 1990

Date Initiated: October 1987

Results/Conclusions: Agreement executed; participation in hatchery TWG and public involvement. Project 87-136, Yaki ma Hatchery: Wapato Canal has been consolidated with Project $88 \cdot 120$.

\section{Date initiated: February 1988}

Results/Conclusions: Good participation and input from irrigation entities.
1. Continuing: Collect baseline data for chinook salmon and steelhead natural production in Yakima basin.

2. Continue through production facilities construction.

\section{Assist in the development of the Yakima} monitoring and evaluation program.
Fy 1991: Participate in public

involvement, TWG, and water analysis.

FY 1992: Continue coordination activities 
OR TASK

NUMBER

$89 \cdot 82$

Experimental Design - WDF

Proiect Manaoer: T, Cl une

Obiectives: Develop experi. mental features of Yakima Hatchery Project. Develop genetic guidelines for stocks of $s$ almon and steelhead for Yaki ma Basin supplementation program. Develop a smolt

trap for the lower Yakima

River to determine distribu.

tion of fall chinook juveniles

89.89 Radiotelemetry Study - NMFS

Proiect Manaoer: T, Clune

Proiect Bioloaist: T, Vogel

Obiectives: Determine the dis. tribution of distinct stocks of Yakima Basin steelhead and spring chinook.

Species Interaction Study - WDW

Proiect Manaaer: T, Clune

Proiect Biolooist: T, Vogel

Obiectives: Determine the ef.

fect of anadromous fish produc.

tion on resident fish. Develop experimental design features

of Yakima Hatchery Project.
PROIECT STATUS

Date Initiated: June 1989

Results/Conclusions: Initial experimental design has been completed. Project 90.66 and 90.67 have been consolidated with this project.

Date Initiated: June 1989

Results/Conclusions: Initial results indicate up to $30 \%$ of steelhead entering the river do not survive to spawning.

\section{Date Initiated: September 1989}

Results/Conclusions: Data collection ongoing. Initial experimental design has been completed. Project 89.83 has been incorporated into this project.

\section{SCHEDULE AND MILESTONES}

Fy 1991: Refine experimental design. Develop genetic guidelines. Develop smolt trap and begin monitoring.

Fy 1992: Refine experimental design and assist in the development of the monitoring and evaluation program. Continue smolt monitoring.

FY 1991: Continue radio tagging and monitoring.

Fy 1992: Continue radio-tagging and monitoring.

FY 1991: Continue study

Fy 1992: Continue study and assist in the development of the monitoring and evaluation program. 
TI TLE

$90-58$

Project Leader Function

- Consultant

Proiect Manaaer: T. Cl une

Objectives: Project was re quested by council to coordinate identification and resolution of fishery management issues associated with the Yakimal Klickitat Production Project. The Project Leader was ap. pointed by the YIN, WDF, and WDW.

Juvenile Monitoring Trap Calibration - NMFS

Proiect Manaaer: T. Cl une

Proiect Bioloaist: T. Vogel

Obiectives: Calibrate Prosser smolt trap for inriver vs. Canal distribution of outmigrating salmon and steelhead.

Yakima Hatchery Final Design

- Consultant

Proiect Manager: $\mathrm{T}, \mathrm{Cl}$ une

Obiectives: Final design of

Yakima Basin Facilities.

\section{STATUS}

Date Initiated: FY 1990

Fy 1991: Continue project.

Results/Conclusions: Project progress- FY 1992: Continue project.
Date Initiated: FY 1990

Results/Conclusions: None at this time. FY 1992: Continue survival studies and assist

in the development of the Yakima monitoring program.
Date Initiated: FY 1991

Results/Conclusions: None at this time. Fy 1992: Continue final design. 
PROJ ECT

OR TASK

NUMBER

$90-71$

Smolt Loss Evaluation

Project Manaoer: T, Clune

Proiect Bioloaist: T, Vogel

Objectives: To determine smolt losses in the Yakima River due to various factors including predation, temperature, and passage conditions.

Adult Trap Predesign - USBR

Proiect Manaaer: $T, \quad \mathrm{Cl}$ une

Obiectives: Predesign of adult trap facilities for the Yakima Hatchery project.

91.48

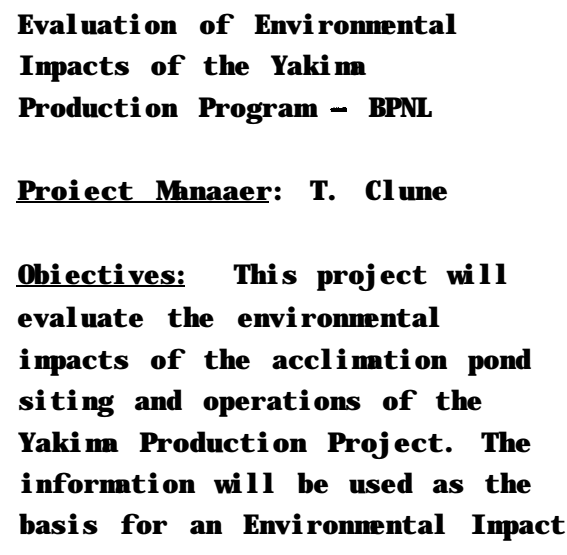

\section{Da}

Results/Conclusions: None

FY 1991: Begin preliminary and final design.

\section{SCHEDULE AND MILESTONES}

Fy 1991: Begin smolt loss evaluation.
Results/Conclusions: None at this time. FY 1992: Continue smolt loss evaluation.

Dat


PROJ ECT

OR TASK

NUMBER

$91 \cdot 55$

Supplementation Fish Quality

Proiect Manaaer: T, Cl une

Obiectives: Define criteria

for setting quality of hatchery

fish for supplementation.

Conduct studies against

established criteria.

$91 \cdot 59$

Habitat Inventory and Food

Abundance Data Collection - CWU

Proiect Manaaer: T. Clune

Obiectives: This project will complete habitat inventories,

determine food abundance, and

integrate data into the central

Washington University GIS.
Expected Start Date: July 1991

STATUS

Expected Start Date: July 1991

Fy 1992: Define criteria and initiate research to determine if the criteria are significant.

Fy 1991: Initiate and complete habitat data

collection. Continue food abundance data collection. 
1II. NEW PROJECTS

PROJECT

OR TASK

NUMBER

90.64

Proiect Manaaer: T, Clune

Project Biolooist: T, Vogel

Obiectives: Monitor spring chinook and steelhead smolts in the hatchery supplementation program. Coordinate with MEG and supplementation TWG's.

$90-72$

Computer Information System Devel opment

Project Bioloaist: T, Vogel

$90-74$
KI ickitat River Monitoring

\section{SCHEDULE AND MILESTONES}

FY 1992: Develop program and initiate monitoring.
New project for FY 1992. Delayed 1990 and 1991. Quality Control Program

Proiect Manaqer: $\mathrm{T}, \mathrm{Cl}$ une

Obiectives: Develop CIS for Yakima/KIickitat supplementation program.

Yakima Monitoring and Eval uation Program

New Project

Proiect Manager: T, Clune
FY 1992: Refine program, coordinate with Basin CIS program.
FY 1992: Initiate monitoring and evaluation. 


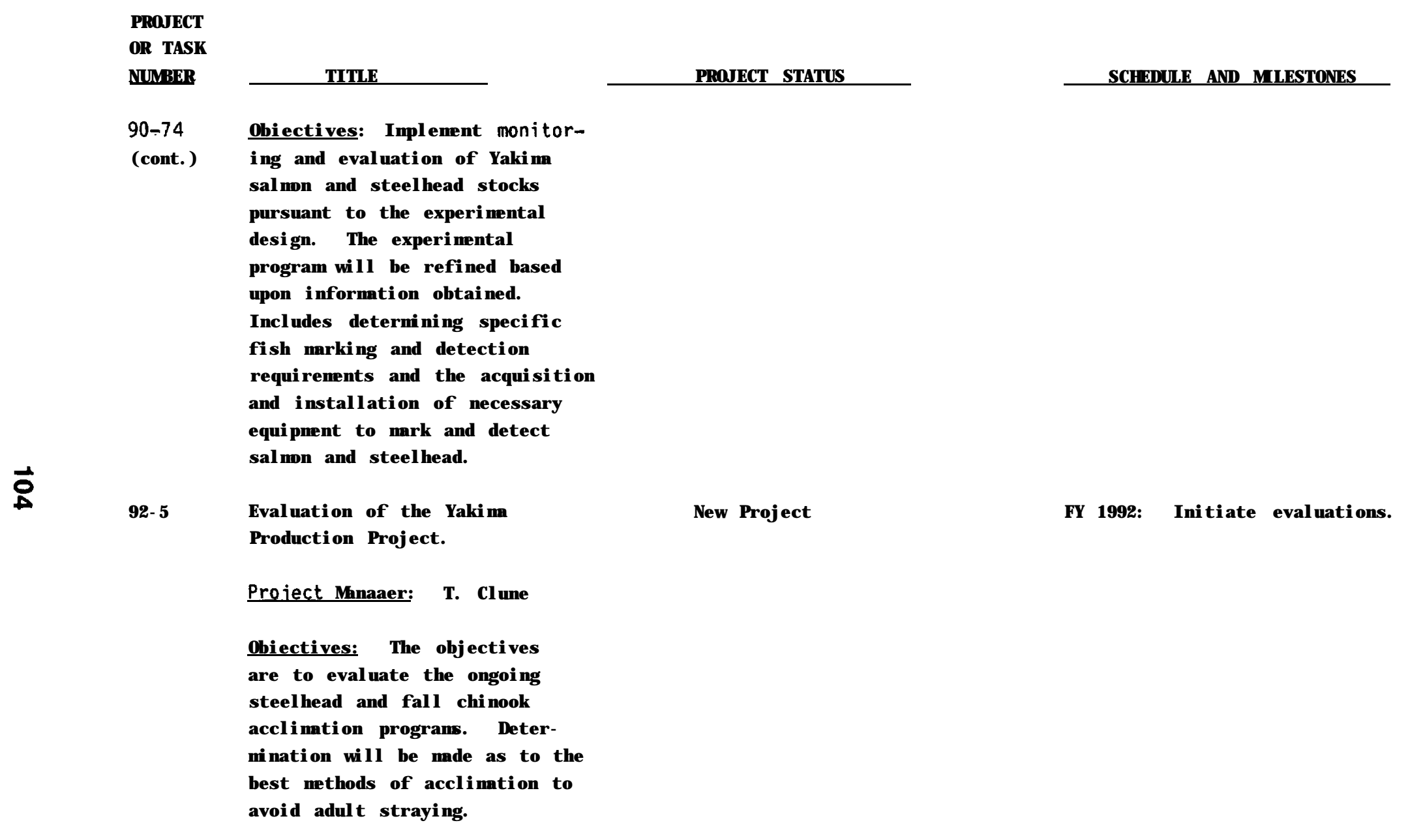


PROJ ECT

OR TASK

NUMBER

TITLE

Habitat Definition, Assessment and I mprovement

Project Manaaer: T, Clune

Obiectives: Define habitat

criteria important to the

experimental program. Measure

habitat parameters based on

established criteria.

Prioritize and begin improve.

ments of critical habitat.
New Project

\section{PROJECT STATUS}

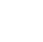

\section{SCHEDULE AND MILESTONES}

Fy 1992: Define critical uncertainties for estimating carrying capacity and begin the determination of critical limiting factors.

FY 1993: Identify, prioritize, and implement habitat improvements necessary to achieve natural production goals. 
4.16.1- NORTHEASTERN OREGON SPRING CHI NOOK OUTPLANTING FACILITY

4.16.2 (Fund Development of Master PIan in FY 1988 or Earlier; Upon Council Approval, Fund Design and Construction>

703(f)(5) BPA shall fund planning, design, construction, operation and maintenance, and evaluation of artificial production facilities to raise sal mon and steelhead for enhancement in the Hood, Umatilla, Walla Walla, Grande Ronde, and I mnaha rivers in oregon. The artificial production facilities shall be used to supplement natural production in these rivers.

\section{ACTION ITEM ACTIVITY SUMMARY:}

Objectives:

To fund Master Plan, design, and construction of the Northeastern Oregon salmon and steelhead facilities.

\section{Backaround and Progress to Date:}

The measure provides for outplanting of about 2.3 million to 3.0 million juveniles in the five Oregon rivers identified in the measure, ODFW, CTWSIR, CTUIR and NPT are preparing Master PIans for each subbasin under contract to BPA. The Master Plans may identify broader production needs in the basin, not all of which would be addressed by this project. Because of independent utility and differences in timing, implementation of the "project" has been disaggregated into discrete projects by subbasins, or groups of subbasins. Current plans are to finalize the Hood River Master PIan (which could be connected to Measure 4,17,6, Pelton Ladder) first, followed by the Umatilla Master PIan, then by the plans for the remaining three subbasins. Phase ll of the plans is to be completed by spring 1992. BPA hired a consulting engineer to conduct site feasibility studies and conceptual design for all subbasins except Hood River, which is being done by ODFW. Work commenced in December 1990 and is to be completed by December 1991.

PI ans:

The Master Plans, including siting and conceptual design, are scheduled to be completed 1991.92. The Council approval process and BPA environmental work will be conducted simultaneously for each discrete project portion. Upon completion of environmental work, BPA will proceed with design, construction, operation, and monitoring of the facilities. 
1. COMPLETED PROJECTS

None.

II. FY 1991 ONGOING PROJECTS

PROJ ECT

NUMBER

88-53 NEOH Siting/Conceptual Design

- Consultant

Proiect officer: J. Marcotte

Obiectives: conduct site

feasibility and conceptual

design for NEOH facilities.

These products will be inte.

grated into the Master PI an

submitted to council. This

objective for Umatilla being

accomplished under separate

contract in conjunction with

Umatilla Satellite Facilities.

88.53.1 Northeastern Oregon Artificial 88-53-2 Production Facilities - CTUIR

88-53-3 CTWSIR/NPT/0DFW

$88-53-4$

Proiect officer: J. Bauer

Obiectives: Fund Master PIan of artificial production program and facilities for NEOH project.

\section{PROJECT STATUS}

Date Initiated: December 1990

Results/Conclusions: Contractor oriented and underway as of February 1991.

\section{Date Lnitiated: PI anning began}

in FY 1988

Results/Conclusions: Contract in place to produce Master PIans.

Phase I complete April 1990. Phase II began May 1990.
SCHEDULE AND MILESTONES

1. July 1991: Final sites and conceptual design, Umatilla.

2. December 1991: Final sites and conceptual design for Grande Ronde, I mnaha, and Walla Walla.

III. NEW PROJECTS

None.

1. FY 1991.1992 (phased): Complete Phase II, including production objectives, monitoring and evaluation, genetic risk assessment, site, and conceptual design of facilities.

2. FY 1991.92: Complete Master Plans.

3. FY 1991.1992: Obtain Council approval of Master PI ans. 
4.17,1 JUVENILE RELEASE/ADULT COLLECTION AND HOLDING FACILITIES ON UMATILLA RESERVATI ON

(Operate, Maintai $n$ >

703(f)(1) [Abstract] BPA shall fund the Confederated Tribes of the Umatilla Reservation (CTUIR) to operate and maintain the Bonifer and Minthorn juvenile release and adult collection and holding facilities on the reservation.

\section{ACTI ON I TEM ACTI VITY SUMMARY}

Objectives:

To fund operation, maintenance, and evaluation of the Bonifer and Minthorn facilities.

\section{Background and Progress to Date:}

The facilities are to acclimate and imprint juvenile salmon and steel head before release into the Umatilla River, thereby increasing survival of juveniles and the homing ability of adults. The facilities are also used to hold adults before artificial spawning. When constructed, the Umatilla Hatchery (Project 84.33; Action Item 4.17.2) will rear juveniles for acclimation at the Minthorn and Bonifer facilities. Currently, juveniles from other hatcheries are acclimated at the facilities.

BPA has funded the operation and maintenance of the Bonifer and Minthorn facilities since construction in 1983 and 1985, respect. ively, During this time, about 1.2 million fall chinook, 800,000 spring chinook, 500,000 coho salmon, and 250,000 steel head juveniles have been acclimated and released. A study to evaluate the fishery benefits and operation of the acclimation facilities was begun in FY 1987 .

Plans:

BPA will continue funding operation, maintenance, and evaluation of the facilities through an Intergovernmental Agreement with the CTUIR as long as there is an Action Item calling for BPA funding. BPA expects that results of the evaluation study will be used by the CTUIR to determine the actual fishery benefits of acclimation, to select effective juvenile release strategies, and to improve operational efficiency. 
1. COMPLETED PROJECTS

None.

1I. FY 1991 ONGOING PROJECTS

PROJ ECT

NUMBER

$83-435$
PROJECT STATUS

Date initiated: FY 1983

Results/Conclusions: Approximately 71,800 fall chinook, 194,800 spring chinook, 132,400 coho, and 59,800 steelhead $\mathrm{j} u$ veniles were acclimated and released during FY 1990. No results of the facility evaluation study are available yet.
SCHEDULE AND MILESTONES

1. Continuing: BPA will fund operation, maintenance, and evaluation of the facilities.

2. Continuing: Contractor will provide an annual operational report and preliminary results of the evaluation study in the Project's annual report.

3. FY 1993: BPA will publish the final results of the evaluation study in a final report. maintain, and evaluate the Minthorn and Bonifer facilities for the acclimation and imprinting of $j$ uvenile anadromous salmonids and the collec. tion and holding of adults.

III. NEW PROJECTS

None 
4.17 .2 EXPANDED UMATILLA HATCHERY

(Fund, upon Council Approval)

703(f)(1)(A) [Abstract] BPA shall fund the construction of a facility to test the efficacy of oxygen supplementation hatchery techniques to produce up to 290,000 pounds of summer steel head and chinook salmon smolts. These smolts shall be for release in the Umatilla juvenile release and adult collection holding facilities and for outplanting in the upper Umatilla River to enhance natural and hatchery production. Prior to construction of this facility, the ODFW and the CTUIR will develop a facility master plan for council approval.

ACTION ITEM ACTIVITY SUMMARY:

Objectives:

To provide an improved contribution of anadromous fish production from the Umatilla River to the Columbia River Basin.

\section{Backaround and Progress to Date:}

The facilities are to produce 290,000 pounds of salmon and steel head juveniles for release in the Umatilla Subbasinto enhance natural and hatchery production. Hatchery production may also be used in other subbasins. A secondary purpose of the hatchery is to demonstrate oxygen supplementation technology. BPA began funding hatchery design in FY 1986 and hatchery master planning in FY 1987. The CTUIR and ODFW have been conducting a release program using fish from other hatcheries since 1982, and intend to continue until this hatchery is operational. The final design was completed during 1988, and the Master PIan was approved in October 1989. Agreement was reached in 1988 that the hatchery will be operated by ODFW as a joint facility with Irrigon Hatchery.

The final design estimates revealed that the hatchery will cost more than originally expected. The cost increases were due to design evolution, delays in project implementation, changing site conditions at the well, and water production shortfalls. Costs rose about $\$ 4.0$ million to total $\$ 12.0$ million. Construction began in March 1990. As of May 1991, construction was al most complete. There is a good chance that costs could come in under budget. Development of the water supply system to start in February 19g1. ODFW began portion of $0 \& M$ contract dealing with construction monitoring and equipment acquisition in Fy 1990. Draft Year 1 Annual Operating Plan was submitted May 9, 1991; and BPA approval is due by July 1, 1991. ODFW is scheduled to take "beneficial occupancy" of the hatchery on July 15, 1991, and have the facility operational by August 15, 1991. 
When the hatchery is completed in 1991, BPA will fund its operation and maintenance. The first fish production is expected to begin in August 1991. After completion, BPA also will evaluate hatchery effectiveness. Planning for satellite facilities began in Fy 1990, with the need to have one or two additional chinook adult holding facilities on line before the mid-1990s. BPA contracted for site feasibility and conceptual design of facilities for direct release, satellite rearing/acclimation, and adult holding in December 1990. Final products are due before December 1991. 
1. COMPLETED PROJECTS

None.

11. FY 1991 ONGOING PROJECTS

PROJECT

NUMBER

84-33

Umatilla Hatchery Construction and O\&M - USACE

Project of ficer: J. Marcotte

Objectives: Design and construct the Umatilla Hatchery.

$\vec{\omega}$
PROIECT STATUS

Date Initiated: FY 1986

Results/Conclusions: Council approved hatchery predesign in October 1986. Hatchery site next to existing Irrigon Hatchery was selected in cooperation wi th Morrow County. Umatilla Hatchery Environmental Assessment was issued February 1987. FONSI issued April 1987.

Council amended Program to expand hatchery production to 160,000 pounds and added salmon to production. Council amended program to expand production to 290,000 pounds and test efficiency of 02 supplementation. Final designs completed. Master PI an complete February 1989. Council approved Master PIan in October 1989. O\&M contract finalized in spring 1990; ODFW began initial preoperation during Summer 1990.
SCHEDULE AND MI LESTONES

1. Winter 1990.1991: Continue construction.

2. Late Summer 1991: Hatchery operational; fund $O \& M$ and monitoring and evaluation. 
PROJECT

NUMBER

$84 \cdot 33 \cdot 3$

$91 \cdot 14$

TITLE

Umatilla Hatchery Tribal Fish Culture Training Program - CTUIR

Proiect officer: J. Marcotte

Obiectives: Train up to eight tribal personnel to qualify as Hatchery Technicians.l for employment in Umatilla Hatchery Program facilities.

Umatilla Satellites - Planning, Date Initiated: FY 1991

Siting, Design, and Construction

- Consultant

Proiect officer: J. Marcotte

Obiectives: Provide complemen. tary facilities for adult hold.

ing for broodstock purposes or required by the Umatilla artificial production program, and for direct release to river. secondary objective may be to provide recovery/acclimation benefits to smolts, trucked from Umatilla Hatchery, prior to release. and Evaluation - ODFW

Proiect officer: J. Bauer

PROJECT STATUS

\section{Date Initiated: September 1988}

Results/Conclusions: Original objectives of 18 months tech experience were met in March 1991. 3 0l $T$ were qualified. Funding to continue salaries and tuition (for academic trainees) will continue until hatchery staff selections made.

Results/Conclusions: A consulting engineer was hired in December 1990 to conduct site feasibility and conceptual design for satellite facilities.

Expected Start Date: August 1991

Results/Conclusions: None at this time. smolts.

\section{SCHEDULE AND MILESTONES}

Fy 1991: Training program completed: funding to continue for salaries and tuition only.
1. Fy 1991: Siting and conceptual design; project definition, based on hatchery program projections; siting study in Umatilla basin.

2. FY 1991.92: Complete environmental work. 3. FY 1992.93: Predesign and final design; begin construction.

4. Fy 1994: Complete construction.
1. FY 1991: Initiate operation of Umatilla Hatchery and begin rearing and marking ChF, ChS, and StS

2. FY 1992: Release first-year production of ChF 


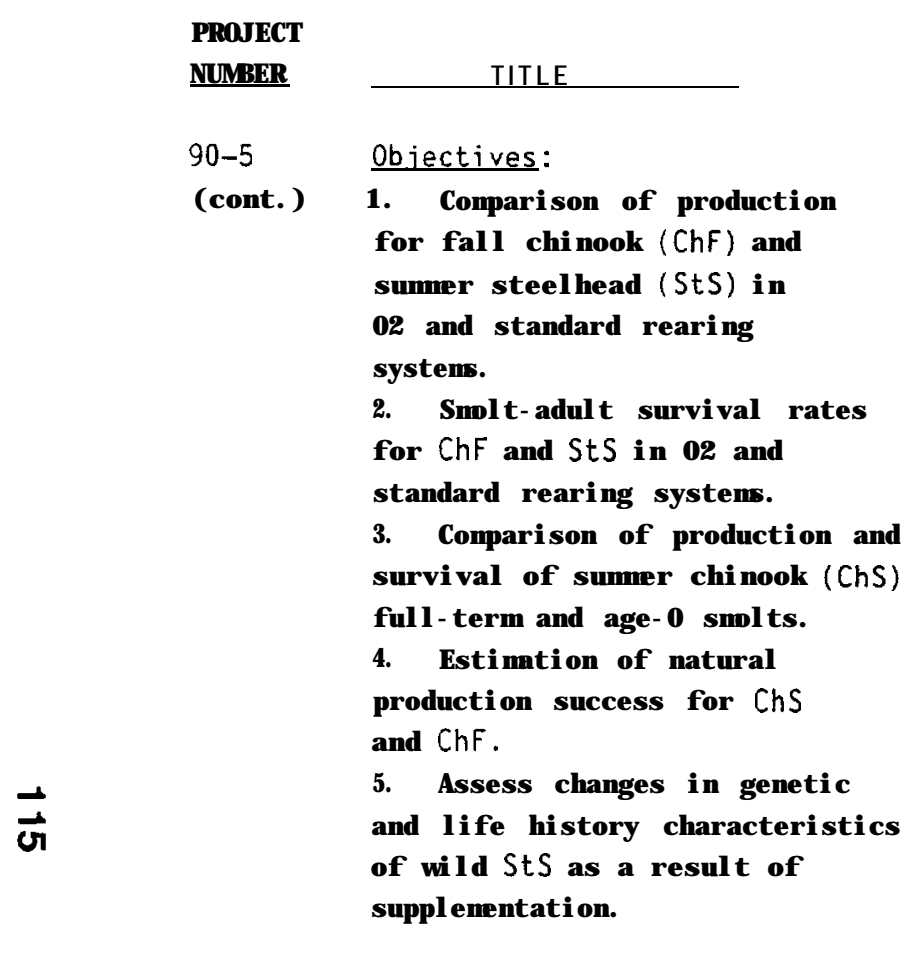

90-5 Objectives:

syst ems.

or ChF and StS in 02 and

tand rearing systems.

and life history characteristics

of wild StS as a result of

supple ment ation.

1II. NEW PROJECTS

None.
SCHEDULE AND MILESTONES

and age-0 ChS and StS from 1991 and 1992 broods Initiate sampling of natural production areas.

3. Fy 1993: Release first full-term ChS smolts and second-year production of ChF, ChS, and StS smolts continue sampling of natural production areas. 
4.17.3 LOW- CAPITAL PROPAGATION FACILITY ON NEZ PERCE RESERVATION

(Design/Begin Construction by May 1989)

703(g)(2) Upon approval by the Council of design and construction plans for low-capital propagation facilities on the Nez Perce Reservation, Bonneville shall fund the construction, operation, and maintenance of those facilities. The Nez Perce Tribe will develop the facility plan and will incorporate the information provided under Section $703(\mathrm{~g})(1)$.

ACTI ON ITEM ACTIVITY SUMMARY:

Objectives:

To design and construct a low-capital production facility to enhance fisheries on Nez Perce Reservation.

Background and Progress to Date:

Through construction of facilities for spawing, incubation, and rearing of chinook salmon and steel head trout, the Nez Perce Tribe (NPT) seeks to re-establish its salmon and steelhead fishery. This fishery has nearly been destroyed through construction and operation of dams and poor land use practices, including agriculture, logging, road construction, and mining.

Work began on this measure in september 1983. The initial phase of the project, which developed an artificial propagation facility feasibility study, was completed in January 1985. Site investi. gations were conducted in FY 1988, FY 1989, and FY 1990.

Plans:

Preli mi nary design scheduled to begin in Fy 1990, followed by environmental evaluation and final design in Fy 1993. Project completion scheduled for Fy 1994. 
1. COMPLETED PROJECTS

\section{None}

II. FY 1991 ONGOING PROJECTS

PROJ ECT

NUMBER

$83 \cdot 350$

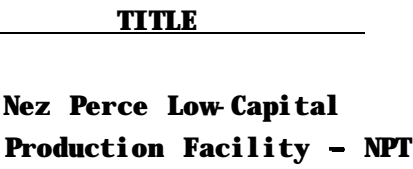

Project officer: S. Levy

Obiectives: Design and construct

a low-cost salmon propagation

facility on the Nez Perce

Reservation.

$\overrightarrow{\vec{\omega}}$

$88 \cdot 126$

Nez Perce Technical

Support - IDFG

Project officer: S. Levy

Obiectives: To provide

technical support on

planning for Nez Perce

Hatchery project.

1II. NEW PROJECTS

None.

\section{PROJECT STATU}

Date Initiated: FY 1983

Results/Conclusions: None at this time
SCHEDULE AND MILESTONES

1. Fy 1991: Amend measure to expand scope of facility, and allow construction of reservation. Continue preliminary design.

2. FY 1993: Complete NEPA assessment. Initiate final design.

3. Fy 1993: Complete final design.

4. Fy 1993: Begin construction, complete project, and begin operation and maintenance.

On-going technical support

will continue through FY 1992.

Results/Conclusions: None. 
4.17.4 HABITAT SURVEY ASSOCIATED WI TH ACTI ON I TEM 4,17,3 (Fund)

703(c)(3) [Abstract] Bonneville shall fund an evaluation of the lower mainstem Clearwater River to study existing habitat and temperature regi mes for spawning, incubation, and rearing for sal mon and steelhead. Proposals for outplanting from the Nez Perce low-capital propagation facilities $[703(g)(2)]$ will be based on the evaluation.

ACTI ON ITEM ACTIVITY SUMMARY:

Obiectives:

To evaluate the habitat and temperature regimes in the lower mainstem Clearwater River; the evaluation will determine the feasibility of establishing a run of anadromous fish.

Background and Progress to Date:

When constructed, a I ow-capital salmon and steel head propagation facility (Action Item 4, 17,3) on the Nez Perce Reservation will produce fish for outplanting in reservation streams. The mainstem Clearwater River habitat study will try to determine what species can successfully be outplanted in the mainstem Clearwater River and to identify opportunities to enhance existing steelhead rearing. BPA expects that the NPT will use study information to plan production and outplanting strategies for the low-capital facility.

BPA began funding a mainstem Clearwater River habitat study (Project 88-15) in October 1987. The study is progressing satisfactorily.

Plans:

Upon completion Project 88.15 in October 1991, Action Item 4.17.4 and measure $703(\mathrm{c})(3)$ will be completed. No additional projects are planned. 
None.

II. FY 1991 ONGOING PROJECTS

PROJ ECT

NUMBER

$88 \cdot 15$

III. NEW PROJECTS

None.
OBJECTI VES

Date Initiated: October 1987

Results/Conclusions: NPT completed Phase lof the project, a literature review and temperature/flow data analysis, and began implementing Phase llfield studies in Fy 1989. The Phase lanalysis of historical temperature data indicated that Lower Clearwater River temperatures are generally suitable for fall and summer chinook salmon reproduction. Instream fl ow field measurements and preliminary velocity, depth, substrate, and cover preference histograms for anadromous fish were completed in Fy 1990. Results are available in annual reports (DOE/BP. 37474.I and DOE/BP.37474-2).
SCHEDULE AND MILESTONES

1. Fy 1991: Complete chinook salmon incubation, rearing, and out migration timing studies; complete all data collection, data analysis, habitat time series modeling, and final report.

2. Fy 1992: Project scheduled for completion in October 1991
Objectives: Evaluate the

existing anadromous fish

River to determine 1) the

feasibility of establishing

run of anadromous species

steel head rearing.

ractin

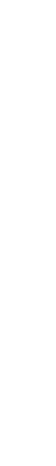


(Former Action Item 34.23)

703(e) [Abstract] Measure 703(e) concerns "I mproved Propagation at Existing Facilities" and gives priority to improving and reprogramming propagation at existing facilities, over construction of new facilities. The measure includes: (1) research, development, and demonstration of i mproved husbandry practices; (2) strategies for and rearing operations aimed at improved operating efficiencies of hatcheries and increased adult returns; (3) genetic stock assessment; (4) i mproved fish health protection; and (5) developing sensitive and reliable indices of smolt quality and readiness to migrate.

\section{TECHNI CAL SUBJECT ACTIVITY SUMMARY:}

Objectives:

To identify and fund research, demonstration, or other projects necessary to accomplish improvements in the effectiveness of existing hatcheries.

Background and Progress to Date:

This section of the AI WP contains three improved hatchery effectiveness and fish health projects begun under former Program Action Item 34.23. In 1987, the Council amended the Program to delete Action Item 34.23 and form a Hatchery Effectiveness Technical Work Group (HETWG) and a Fish Disease Technical Work Group (FDTWG). These groups, composed of experts in hatchery effectiveness and fish health, developed Five-Year Research Work PI ans to address the technical needs of the Hatchery Effectiveness and Fish Disease Research Areas of Emphasis, Section 206(b)(1)(c), and Program Measure 703(e). These plans are discussed under Action Item 6,1 in the AIWP.

BPA continues to fund to completion those projects begun under former Action Item 34.23. One of the currently funded projects is conducting research on infectious hematopoietic necrosis (IHN) virus. This disease was rated as one of the most important disease problems by the FDTWG in its Work PIan. Other projects are pursuing fish nutrition research and identification of the ceratomuxa shasta life cycle. All three are scheduled for completion in Fy 1991.

\section{Plans:}

No new projects will be initiated under Action Item 34.23, as it was deleted from the 1987 Program. (New and ongoing projects from the HETWG and FDTWG Five-Year Work PIans can be found under Action ltem 6.2 in the AIWP.) 
1. COMPLETED PROJECTS

PROJ ECT

NUMBER

$83 \cdot 312$

Epidemiology and Control of Infectious Diseases of

Salmonids in the Columbia

River Basin - OSU

Proiect officer: A. Ruger

Objectives:

1. Confirm role of clam as a concentrator of $C$. shasta

2. Determine if $C$, shasta spores undergo any developmental

changes when injested by clams.

3. Develop a diagnostic test

kit for $R$, salmoninarum caus-

itive agent of $B K D$.

Evaluation of a Subunit

Vaccine Against IHN Virus - OSU

Proiect officer: R. Morinaka

Objectives: Develop and test a subunit vaccine against IHN

virus.
PROIECT STATUS

Date Completed: March 31, 1991

\section{Results/Conclusions:}

1. Geographic range of $C$. shasta

expanded.

2. Indication that a fresh water clam

is involved in life cycle of C. shasta.

3. I mmunological methods developed to detect life stages.

Expected Completion Date: July 1991

Results/Conclusions: A recombinant DNA vaccine for IHN virus has been prepared and Iaboratory tested and found to be effective. Large quantities of vaccine have been prepared. I DFG is continuing to field test the vaccine in 1990-91. 
PROJ ECT

NUMBER

TITLE
Development of Diets for
Enhanced Survival of Salmon -
ODFW

Proiect officer: R. Austin

Obiectives: Develop a high-

quality, coldeprocessed

animal protein fish diet and

evaluate the effect of the diet

on survival and return of coho

and chinook salmon.

Expected Completion Date: June 1991

Results/Conclusions: Preliminary adult

recovery data suggest an improved

survival for coho salmon fed the test

diets. However, recovery data for

adult fall chinook salmon showed in.

consistent survival, both by brood year

and stock (tule and upriver bright).

Final analysis of data from returning

adults will be completed in 1991.

\section{FY 1991 ONGOING PROJECTS}

None.

1II. NEW PROJECTS

Hatchery Effectiveness research projects in the five.Year Work Plan of the Hetwo are listed under Action Item 6.2. 
$4,17,5$ WI LLAMETTE BASIN STUDY PLAN

(Fund; Coordinate with Supplementation Work PIan)

703(h)(2) [Abstract] BPA shall provide funds to study the best method of supplementing natural stocks of spring chinook wi th hatchery stocks in the Willamette River.

\section{ACTION ITEM ACTIVITY SUMMARY:}

Objectives:

To fund a study to supplement the Willamette spring chinook runs wi thout adversely affecting natural runs of resident fishery or the genetic integrity of the Columbia Basin fish populations.

\section{Backaround and Progress to Date:}

Supplementation, or outplanting, has been identified by the agencies, Tribes, and the council as one of the main ways to increase columbia River salmon and steelhead runs. This project ai ms to develop the best methods for supplementing spring chinook in the Willamette Basin, in order to develop and maintain maximum sustained yield and to maintain genetic diversity.

Phase I, completed during September 1985, surveyed the literature of outplanting efforts and developed a detailed study design for evaluating possible Willamette Basin strategies. Phase II proposed planting fry, presmolts, and adults in areas with different production potential. The 9-year evaluation would determine which I ife stage of spring chinook to outplant for maximum survival.

A major review included the study design and the relationship to Section $703(h)(1)$, the overall work plan for supplementation.

Section $703(h)(2)$ concerns only Willamette Basin spring chinook. The review, completed in Fy 1986, concluded that the initial study design viewed outplanting as a potential continuing effort to supplement hatchery production by using hatchery surpluses. However, both Measures $703(h)(1)$ and $703(h)(2)$ view outplanting as a temporary means of enhancing natural production or re-establishing natural runs, Rebuilding natural runs was not addressed in the study plan, though it is one of the highest priorities of the Program.

The impacts of outplanting on resident fish will not be answered by this study design. BPA believes, however, that these impacts should be addressed in supplementation research.

\section{Plans:}

BPA submitted the study plan to the STWG for review, realizing the relationship with $703(h)(1)$ that this study should address. Measure 703(h)(2) was not a high priority in the STWG Five-Year Work PIan. However, BPA will develop a work plan and initiate research when and if the STWG determines it is a high priority for achieving the objectives of the Supplementation Research Work PIan. 
Projects:

No BPA-funded projects are planned for FY 1992. 


\subsubsection{PROPAGATION OF SALMON/STEELHEAD IN PELTON DAM FISH LADDER}

( $F$ und, upon Council approval of Master PIan)

703 $(\mathrm{g})(3)$ BPA shall fund propagation of $\mathrm{sal}$ mon and/or steel head smolts in the 2.8. mile-long fish ladder located at Pelton Dam on the Deschutes River in Oregon. This production shall be in addition to the fish propagated in the Iadder by Portland General Electric to mitigate the.effects of Pelton and Round Butte dams and will not affect the mitigation responsibilities of that company. The Oregon Department of Fish and Wildlife and the Confederated Tribes of Warm Springs will develop a master plan for council approval prior to BPA funding of design and construction. The master plan should contain the same type of information as in other hatchery master plans for Yakima, Umatilla, and northeastern Oregon facilities.

ACTI ON ITEM ACTIVITY SUMMARY:

Objectives:

Fund the design and construction of propagation facilities at the Pelton Dam Iadder; fund the propagation of salmon and/or steel head.

Backaround and Progress to Date:

BPA is a waiting development of the master plan by the fisheries agencies and Tribes. The Master PIan will be complete June 1991.

Plans:

When the Council approves the agency and Tribal joint master plan for the Pelton Dam I adder rearing, BPA will form a work group to assist in the completion of this Action Item. The design and construction will follow the recommendation of this work group. When the facility is constructed, an operation and maintenance agreement wi th the operator will be established. 
1. COMPLETED PROJECTS

None.

11. FY 1991 ONGOING PROJECTS

PROJ ECT

NUMBER

$89 \cdot 29$

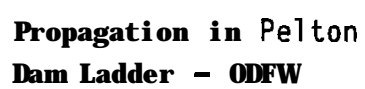

Proiect of ficer: J. Bauer

Objectives:

1. To experimentally rear

spring chinook smolts in Pelton

Ladder .

2. To determine the capacity

for additional rearing of smolts.

3. To produce spring chinook

smolts for Deschutes River and

other acceptable basins to meet

Program production goals.

\section{PROJECT STATUS}

\section{Date Initiated: September 1989}

Results/Conclusions: None at this time.

III. NEW PROJECTS

None.

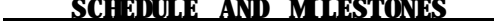

1. Fy 1991: After Council approval of the ODFW-CTWSIR master plan, BPA will fund rearing of fish in the Pelton Dam fish ladder.

2. FY 1992: Begin rearing spring chinook s molts.

3. Fy 1994: First smolt releases.

4. Fy 1998: Final report on experiment to determine ladder rearing capacity. 
4.21 HATCHERY RELEASES IN UPPER COLUMBIA

(Upon Council Review of Reprogramming PIan, Fund Releases)

703(d)(2) After council review of the reprogramming plan developed by the fish and wildlife agencies and Indian Tribes, BPA shall provide funds to transfer a portion of the fish from existing lower Col umbia River hatcheries to release sites in the upper columbia River system to assist in restoring naturally spawning stocks, as provided in that plan.

ACTI ON ITEM ACTIVITY SUMMARY:

Objectives:

To i mplement the reprogramming plan (approved by the council> to assist in the rebuilding of upriver fish runs.

Background and Progress to Date:

BPA understands that the fishery agencies and Tribes have not submitted the plan to the council. When the council has reviewed the plan, BPA will proceed with funding of hatchery releases in the upper Columbia River. BPA still awaits Council review and approval of the plan.

Plans:

Future projects and required funding will be identified after the Council approves the reprogramming plan.

\section{Projects:}

No defined projects for FY 1992. 
5.1 KNOWN STOCK FISHERIES FIVE-YEAR DEMONSTRATI ON PROGRAM (Co.Fund to Test Electrophoresis: Begin 1985 Ocean Fishing Season or Subsequent Seasons)

$503(b)(1) \quad$ The council supports in-season management of mi xed-stock fisheries using electrophoresis to profile the contribution of the different upriver stocks. BPA shall share funding with the fishery management agencies of a five-year program that demonstrates the effectiveness of this technique in profiling the ocean fisheries more accurately and in refining harvest regulations to protect Columbia River stocks. At the conclusion of the five-year program, the fishery management agencies will propose a plan for further action.

ACTION ITEM ACTIVITY SUMMARY:

Objectives:

To demonstrate the effectiveness of the electrophoresis technique for profiling the contribution of individual Columbia River stocks in mi xed populations.

Backsround and Progress to Date:

BPA contributed funds to a study to perfect the electrophoresis technique to differentiate fish stocks and to demonstrate its applicability in the Columbia River Basin (Project 79-l). BPA funded further application of this technique (Project 83.451) to determine separate stocks of Columbia Basin anadromous fish. These efforts and those of the fishery management entities have produced a proven electrophoresis technique. This technique is now widely applied in fisheries management and could be applied to profile mi xed stock ocean fisheries. The technique may also soon be used to determine whether sturgeon populations in the United States stretches of the Kootenai River are different from those in Canadian waters. BPA therefore believes that further research to improve stock identification methods as part of a hydroelectric mitigation program is unnecessary. Stock identification is now a matter of prescriptive application.

PI ans:

BPA has no further plans for this Action ltem.

\section{Projects:}

None. 
6.1 TECHNICAL WORK GROUPS

(Begin to Fund in FY 1987)

206(b)(1) [Abstract] BPA shall focus its funding of sal mon and steel head research in the next five years in the following areas of emphasis:

1. Studying water budget effectiveness and reservoir mortality;

2. Controlling disease problems affecting spring and summer chinook;

3. Exploring methods for substantially increasing and i mproving hatchery production at existing hatcheries within the next 10 years; and

4. I mproving supplementation techniques.

BPA shall fund technical work groups composed of representatives of the Fish and Wildlife agencies, tribes, hydropower project operators, and BPA, wi th technical input from other experts, to develop Five-Year Work PIans for each of the areas listed above.

ACTION ITEM ACTIVITY SUMMARY:

objectives:

To fund the establishment of a TWG in each of the four areas of research emphasis and to fund the development of Five-Year Work PIans.

Background and Progress to Date:

In 1987, BPA initiated Project 87.307 to fund development of Five-Year Work PIans by the four TWGs and to fund TWG assistance to BPA in the development, evaluation, and review of requests for proposals, project work statements, and other related documents.

The Fish Disease TWG, Hatchery Effectiveness TWG, and Supplementation TWG developed Five-Year Work PIans that were approved by the Council in 1988. The Reservoir Mortality and Water Budget Effectiveness TWG agreed on four areas of emphasis: survival and flow relationships, predation, smoltification, and dam operations. As opinion was distinctly divided on the focus of survival and flow relationships, two Work Plans were submitted to the Council in september 1987. The fishery agencies/Tribes plan emphasized long-term monitoring to determine the effectiveness of the Water Budget and examination of the mechanisms of reservoir mortality. The BPA/USACE/PNUCC plan emphasized shorter-term survival research and simultaneous research on both the extent and mechanisms involved in reservoir mortality. This latter plan also maintains a basal monitoring program.

In 1990, seven Scoping Groups (SG) were established under the I mplementation PI anning Process (IPP). The function of the SG's was to assist BPA in the scoping and prioritization of new projects, 
including research projects in the Five Year Work PIans, and in the development of requests for proposals. Therefore, BPA no longer needed any assistance from the TWGs, and Project 87.307 was termi nated in March 1991.

Plans:

BPA currently has no plans to fund any TWG activities in FY 1992. 


\section{COMPLETED PROJECTS}

PROJ ECT

NUMBER

$87 \cdot 307$

Technical Work Group (TWG)

Coordination - PSMFC

Proiect of ficer: J, Gislason

Obiectives:

1. Coordinate Council Area of

Research Emphasis TWG activi.

ties within the TWG's and among

the TWG's, as required by the

I mplementation PI anning Process

(IPP).

2. Coordinate TWG planning

activities with other activities

such and MEG and system and

Subbasin PIanning, as required

by the IPP.

\section{FY 1991 ONGOING PROJECTS}

None.

III. NEW PROJECTS

None.
PROJ ECT STATUS

Date Completed: March 1991

Results/Conclusions: The four TWGs

developed Five-Year Work PIans that

were submitted to the Council in 1987

or 1988. 
6.2 RESEARCH IN THE FIVE-YEAR WORK PLANS

(Begin to Fund in FY 1988)

404

$703(e)$

$703(h)$

[Abstract] These measures address BPA funding of research, 206 (b)

devel opment, and testing of i mproved fish husbandry practices, rearing operations, release strategies, stock assessment, fish health protection, indices of smolt quality, and hatchery supplementation. Measure 206(b) in the Program directs BPA to focus its funding of salmon and steel head research in the next five years in the four areas of emphasis described under Action Item 6.1 in BPA's Work Plan. Technical Work Groups in each of the areas of emphasis will develop a Five-Year Research Work PI an for Council approval and BPA funding beginning in FY 1988.

\section{ACTI ON ITEM ACTIVITY SUMMARY:}

\section{Objectives:}

To fund research identified by the TWGs in the Five-Year Research Work PIans.

\section{Background and Progress to Date:}

The Council Technical Work Group (TWG) process was instituted to focus research planning in four areas of technical emphasis considered fundamental to the success of the Fish and Wildife Program. The four TWGs (Reservoir Mortality and Water Budget Effectiveness, Fish Disease, Hatchery Effectiveness, and Supplementation> submitted Five-Year Research Work Plans in 1987 or early 1988 for council review and approval. BPA began funding projects from the Work PIans in late FY 1988.

\section{Plans:}

During an I mplementation PIanning Process review of BPA's FY 1992 budget, the Policy Review Group recommended that hatchery effectiveness and fish disease research be de-emphasized and funding levels be reduced in Fy 1992. In response to this recommendation, BPA reduced the amount of funds for hatchery effectiveness and fish disease research in its Fy 1992 I RB submittal to Congress. The reduced funding was insufficient to fund all proposed and onging projects in Fy 1992, requiring prioritization of projects and subsequent termination, curtail ment, or deferral of low priority projects in FY 1992.

The PRG requested the Artificial Propagation Scoping Group (APSG) to provide a recommended ranking of projects in RPAF1113 (RPAF1113 is the segment of BPA's Fish and Wi I dl ife Program budget containing all hatchery effectiveness and fish disease research projects). The recommendations of several individual APSG members were presented to the PRG on May 16, 1991. Since there was no consensus among the APSG members, BPA modified slightly the ranked list of projects that it al ready had provided to the PRG at the April 18, 1991, PRG meeting: 


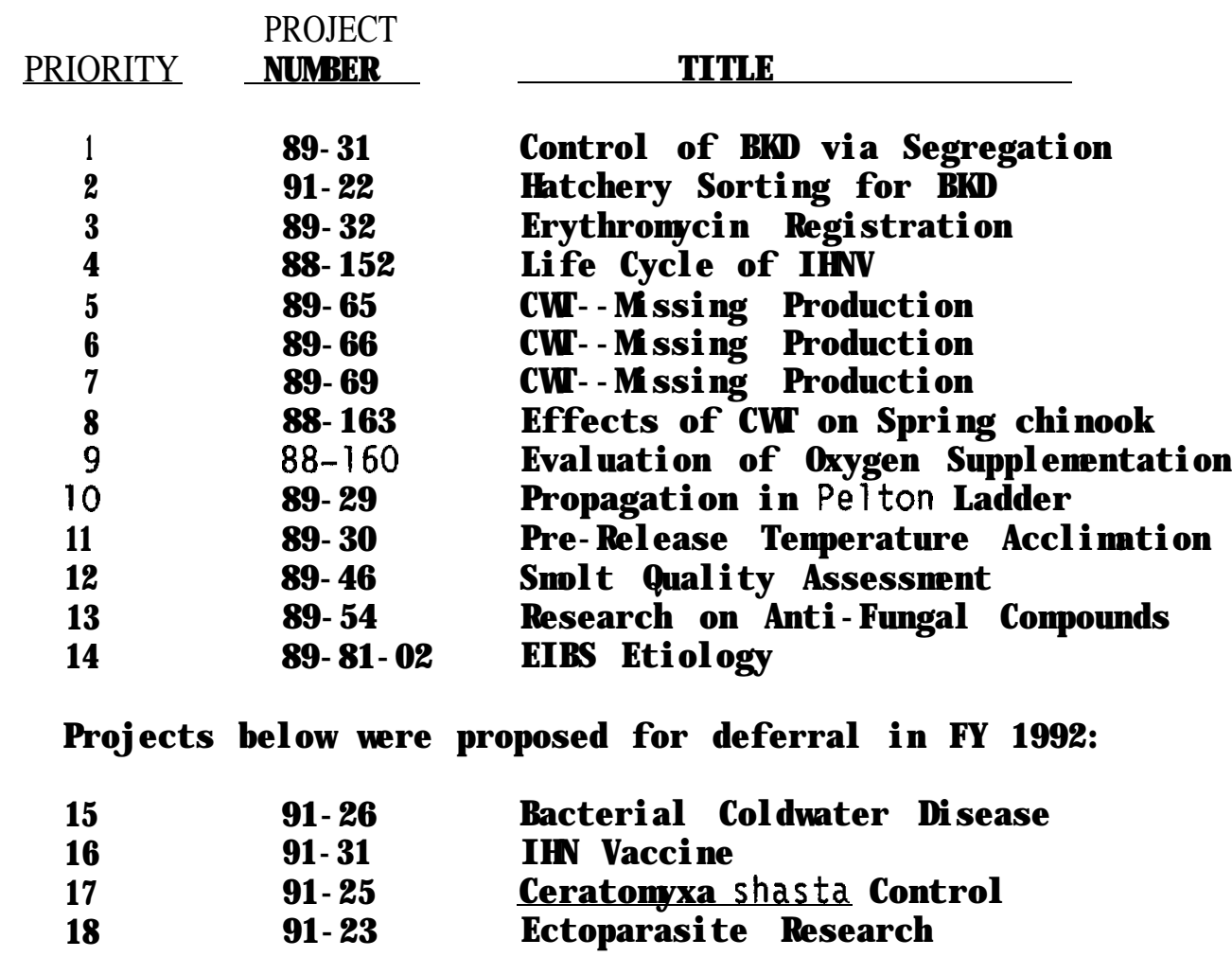

BPA used the following criteria to develop its ranked list:

- Key projects concerning the two main disease pathogens, BKD and IHN.

- Key knowledge needed: Evaluation of hatcheries.

- Key technology needed: 1. The effect of oxygen on survival

2 The effects of acclimation ponds.

3. Antifungal replacement.

To carry out the PRG's recommendation to reduce fish health/hatchery effectiveness research, BPA will defer the four lowest-priority projects (Project 91-26, 91-31, 91-25, and 91-23) in Fy 1992. 
1. COMPLETED PROJECTS

PROJ ECT

NUMBER

87.413.1 Fish Survival and $5 \mathrm{molt}$

I Task Physiology/Behavi or Workshops

Order $\quad-$ UW/ BPNL

97678

\section{Project officer: P. Poe}

Obiectives: Through the work. shop process:

1. Better define measurements of $s$ almon and steelhead smolt survival and smolt condition.

3. Present recommendations on how to proceed with future survival and smolt condition research.

4. Provide workshop results as one source of information to assist the Reservoir Mortal. ity and Water Budget Effective. ness Technical Work Group in their development of a 5-year Work PIan for mainstem passage research.

\section{PROJECT STATUS}

Date Completed: FY 1991

Results/Conclusions: Proceedings from

Smolt Survival Workshop conducted Feb.

ruary 1989 are available (DOE/BP.35885-2,

January 1990). Avenues of research were

identified to clarify and reduce

uncertainty in survival estimates and

their application in program evaluation.

Work on juvenile salmonid survival

estimation and analysis techniques is

continuing under Project 86.118 (Task

Order No. 10) where a team of technical

experts has been assembled to develop

survival experimental designs and re.

search methods.

Related work on the smolt physiology of hatchery-reared spring chinook is ongoing under Project 89.46. Related work on the physiology of wild and natural smolts in the Snake River Basin is proposed to occur under EsA Habitat/ Production Measure 5.3. 
88.134 Evaluation of Factors Affecting Expected Completion Date: Fy 1991 Collection Efficiency Estimates at Mc Nary Dam - NMF S

Results/Conclusions: Field data from

Proiect officer: P. Poe

two years of research have been collected and analyzed. Recommendations to improve the accuracy of estimates of collection obiectives: Assess potential efficiency have been made, and when sources of error associated with implemented, will improve the precision estimates of juvenile fish col. of daily fish passage estimates at lection efficiency and improve Columbia River dams.

techniques for estimating col. lection efficiency at McNary Dam. Study will use PIT tags to evaluate effects of fish origin, time of day of release, and the use of guided fish for test fish on collection ef. ficiency results.

Developing a Predation Index and Evaluating Ways to Reduce Salmonid Losses to Predation in the Columbia River Basin - ODFW

Proiect officer: W. Maslen

Obiectives: Develop and eval. uate squawish harvest tech. ni ques.

\section{Date Completed: December 1990}

Results/Conclusions: An index for estimating abundance of squafish was refined, for use in combination with the consumption index (Project 82.3) to determine the significance of predation.

A plan was developed for step-wise i mplementation of commercial and sport reward fisheries on squawish on a system-wide basis (Project 90-77).

Project terminated December 1990. Addi. tional development of squawish harvest techniques has been integrated into Project $90 \cdot 77$. 
PROJ ECT

NUMBER

\author{
TITLE \\ Significance of Predation \\ and Development of Prey \\ Salmonids in the Columbia and \\ Snake River Reservoirs.

\section{Proiect officer: W. Maslen} \\ Obiectives: \\ 1. Determine if substandard \\ juvenile salmonids (dead, \\ injured, stressed, diseased, \\ naive) are more vulnerable than \\ standard or normal juvenile \\ sal monids. \\ 2. Develop and test $s$ molt \\ protection measures to control \\ predation on juvenile salmonids \\ by reducing predator-smolt \\ encounters or predator capture \\ efficiency.
}

Protection Measures for Juvenile Results/Conclusions: In situ field

Passive Integrated Transponder (PIT) Tag Research - NMFS

\section{Proiect officer:}

V. Jagendor

\section{Obiectives:}

1. Determine the biological feasibility of injecting salmon and steelhead with PIT tags for passage and monitoring research activities. tests of prey selection were shown to be feasible in 1990. Project will now focus on studies in the field that depict real-world conditions.
Date Initiated: 1983

Results/Conclusions: All data to date show that there are no biological problems with the PIT tag. The detection systems and monitors continue to be i mproved and are working extremely well. Adult chinook salmon with PIT tags have been detected at Lower Granite Dam.

\section{SCHEDULE AND MILESTONES}

Fy 1991: Continue prey selection experimentation in the laboratory and the field to determine relationship between predation and prey condition and develop and evaluate prey protective measures (e.g., reducing predator-prey encounters, reducing predator feeding efficiency, etc.).
1. FY 1992: BPA will fund the project through to completion. Biological studies on adult salmon will continue until completed, and monitoring hardware will continue to be developed.

2. Continuing: Contractor will finalize biological studies and equipment development and provide evaluation reports annually. 
PROJECT

NUMBER

$83 \cdot 319$

cont.

2. Determine biological and engineering feasibility of adult and smolt salmon and steel head detection facilities for passage monitoring and research activ. ities.

87-413-2 Analysis of Historic Data for I Task Juvenile and Adult Salmonids Order - uw

01772)

Objectives: Phase I of t stically bounded ti mates of survival from smolt to adult and contribution rates
Date Initiated: September 1989

Results/Conclusions: A data base of

survivals and variances and/or contri.

bution rates of Columbia River hatchery

stocks was produced from the assembly and analysis of CWT data under Phase $I$.

Phase II will assemble riverine factors, apply the methods developed under Phase $I$,

and explore multivariate relationships

to survival. A report of Phase I

activities will be available in Fy 1991.

\section{SCHEDULE AND MILESTONES}

FY 1992: Continue Phase II through to completion to ocean fisheries for columbia River salmon and steel head hatchery stocks based on the last 15 years of Coded-Wire Tag (CWT) data. Phase II of this research will consist of the analysis of the adult production and survival data base created in Phase I in relation to riverine factors that affect production and survival, Phase II will be funded upon outcome of Phase I. 
PROJ ECT

NUMBER

$88 \cdot 141$

Biological Manipulation of Migration Rate and Recovery Rate - The Use of Advanced Photoperiod to Accelerate Smoltification in Yearling Chinook Sal mon - NMF S

Proiect officer: W. Maslen

Obiectives: Assess the effect of advanced photoperiod and release timing on smolt develop. ment and migration timing.

Development of Epidemiological Methods for Use in Quantifying Survival Relationships from PIT Tag Releases of $S$ almon and Steel head smolts - UW

Proiect officer: P. Poe

Obiectives:

1. Phase 1: Develop epidemiological models and regression estimators, tests of survival relationships, and tests of assumptions and goodness-of - fit statistics. Phase II: Determine location and number of required PIT-tag facilities, develop sample size calculations for PIT tag release studies, conduct computer studies of robustness of models, develop alternative scenarios for PIT tag studies, and develop computer package for statistical design and analysis.

\section{Date Initiated: May 1988}

Results/Conclusions: Results from the testing in 1988, 1989, and 1990 show travel time and recovery rates of juvenile yearling chinook can be enhanced through biological manipulation of physi ol ogical development.
SCHEDULE AND MILESTONES

FY 1992: Evaluate effect of photoperiod treatment and timing of release on migration rate and recovery rate of juvenile spring chinook at Kooskia Hatchery.
Date Initiated October 1989

Results/Conclusions: Under Phase 1 , the 2 statistical capabilities to analyze complex statistical models for PIT tag release studies that incorporate pre. release covariates were developed. A report of Phase I activities will be available in Fy 1991.
1. Fy 1992: Continue Phase II tasks. completion. 
PROJ ECT

NUMBER

$90-77$

\section{TI TLE}

Development of a System-Wide

Predator Control Program - ODFW

\section{Project of ficer: W. Masl en}

\section{Obiectives:}

1. Determine the significance of predation in Columbia River reservoirs through implementa. tion of indexing of predator abundance and integration with consumption indices.

2. I mplement squawfish management throughout the Lower Columbia and snake Rivers.

3. I mplement an evaluation of the Squawfish Management Program.

System- Wide Significance of Predation on Juvenile Sal monids in Columbia and Snake River Reservoir - USFWS

\section{Project Officer: W. Masl en}

\section{Obiectives:}

1. Index predator consumption rates of juvenile salmonids in reservoirs of the Lower Columbi and Snake River Basin.

2. Assist ODFW (Project 90.77)

to index predator abundance,

\section{PROJECT STATUS}

\section{Date Initiated: April 1990}

Results/Conclusions: Indexing of the significance of predation was conducted in the Lower Columbia River (Bonneville to I ce Harbor Dam.) A pilot test fishwas initiated in the John Day Reservoir to evaluate the feasibility of commerand sport reward fisheries. Baseline data were collected for evaluation of squawfish management.

Squawfish abundance was indexed in the Lower Columbia River (Bonneville to Ice Harbor) in 1990 and Lower Snake River (I ce Harbor to Hells Canyon) in 1991. Abundance indices in the Lower Columbia were higher downstream of John Day, relative to the John Day reservoir. Tailrace generally had the highest catch per unit effort, but Bonneville forebay was also relatively high. Catch per unit effort was over twice that of upstream locations.

\section{Date Initiated: March 1990}

Results/Conclusions: Squawfish consumption was indexed in the Lower Columbia River (Bonneville to Ice Harbor) in 1990 and Lower Snake River (I ce Harbor to Hells Canyon) in 1991. Consumption indices were highest during the summer in tailraces of McNary, John Day, and Bonneville Dams. Consumption indices were intermediate in forebays and lowest in mid-reservoir locations. The boatrestricted zones of tailraces and forebays had the the highest consumption
FY 1992 and beyond: Continue implementation and evaluation of squawfish management throughout the Lower Columbia and Snake Rivers.

FY 1992: Continue integration of consumption indices with abundance indices to determine the significance of predation in the Lower Columbia and snake Rivers relative to John Day reservoir.

Continue to assist ODFW in the implementation and evaluation of the squawish managent program. 
PROJ ECT

NUMBER

$90 \cdot 78$

cont.

$\overrightarrow{\mathrm{E}}$

indices.

integrate predator abundance

and consumption indices to

estimate system-wide losses of

juvenile salmonids to predators.

Continue to provide support to

i mplement, manage, and evaluate

squawf ish management program.

86.118 Feasibility of Satisfying

(Task Model Assumptions of the

Order 10) Burnham and Anderson Fish

Survival Estimation Techniques

Project of icer: P. Po

Obiectives:

1. Evaluate the practicability

of applying the Burnham and

Anderson model to improve

estimates of $s$ molt survival

in the Columbia River system.

2. Evaluate how the practical

problems related to conducting

the survival experiments may

limit the ability to satisfy

the model assumptions.

91.17 Investigation of Factors

Af fecting Migrations of Juven.

ile Spring Chinook above and

through Lower Granite Reservoir

Proiect officer: P. Poe

Obiectives: Investigate

factors affecting the migration and survival of juvenile wild natural and hatchery produced

Date Initiated: September 1990

Results/Conclusions: Scoping session reviewed survival estimation techniques in January 1991. Technical team is developing "strawman" experiment(s).

\section{Date Initiated: February 1991}

Results/Conclusions: This project is

planned to be conducted in two phases. Phase I will perform literature review identify data needs, and assemble tech. nical work group to define project scope, long-term objectives, and feasibility, and develop study $\mathrm{plan}$ and experimental design. Phase ll will implement field studies and report results. Phase I
FY 1991: Continue model evaluation; develop experimental designs for implementation.

Fy 1992: Project is scheduled for completion: final report in Fy 1992.

FY 1992 and beyond: Conduct Phase II, Perform field studies and report results. 
PROJ ECT

NUMBER

$91 \cdot 17$

cont.

$91 \cdot 29$
Lower Granite Reservoir.

Early Life History Requirements of Subyearling Chinook Salmon

i n Col umbia River Basin

Reservoirs - USFWS

Proiect officer: $D$. Watkins

Objectives:

1. Identify and describe the characteristics of fall chinook sal mon spawning habitat in the

snake River, and estimate the

extent of utilization and

production of emergent fry.

2. Identify and describe the

characteristics of rearing

habitats used by subyearling

chinook salmon in mainstem

reservoirs.

3. Describe the factors in.

fluencing the migratory

behavior of subyearling chinook

sal mon in mainstem reservoirs.

4. Determine the relationship

between survival of migrating

fall chinook juveniles and

various flow regimes.

5. Synthesize data and prepare

final report. corporated as part of Project 90.51 ( See

Appendi $\mathrm{x}$ B).

Expected Start Date: September 1991

Results/Conclusions: None at this time. Fy 1992.94: Document spawning, describe spawning habitat and determine the rearing habitats of fall chinook sal mon.

Fy 1992.96: Determine subyearling chinook migratory requirements and the flow/survival relationship for various flow regimes.

1II. NEW PROJECTS

None. 
PROJ ECT

NUMBER

$89 \cdot 30$

\section{Evaluation of Pre.Release}

Temperature Acclimation at

"Ground Water" Hatcheries - WDF

Proiect officer:

A. Ruger

obiectives:

1. To provide KIickitat River accli mation water to the Klickitat Hatchery site.

2. Compare the performance

(survival of adults to hatchery rack) of spring chinook smolts

raised in and released directly

from a groundwater supplied

hatchery to smolts released from

the same hatchery following ac.

climation with the ambient

tributary receiving water for a

period of time before release.

Spring Chinook Smolt Quality Assessment - NMFS

\section{Proiect officer: R. Austin}

Obiectives:

1. Select and monitor fish quality at four hatcheries.

2. Correlate these data with overall survival of the re.

leased groups (total contribution).

3. Determine suitability of smolt quality indices and other physiological parameters for assessing fish quality and i mproving hatchery effective-
PROIECT STATUS

Date Initiated: July 1989

Results/Conclusions: Construction for delivery of water to rearing area complete.

Date Initiated: February 1989

\section{Results/Conclusions:}

1. Sampling during the first two years at four hatcheries indicated that most fish were released prior to the initiation of the smoltification process.

2. Significant differences were noted in upriver vs, downstream hatchery re. leases in degree of smoltification.

3. Sampling is continuing.

4. Developed plan for monitoring physiological parameters of wild smolts.

5. Results to date are summarized in the
1. July 1, 1989 - Dec, 30, 1990: Feasibility and engineering studies and construction to provide river water to the hatchery site.

2. September 1990: Start coded-wire tag fish for 4 years.

3. August 1992: Start sampling coded-wire tags for 5 years.

4. June 30, 1998: Final report and project completion.

1. Fy 1991: Continue to characterize physiological parameters for hatchery spring chinook in at least three subbasins; upon approval, initiate monitoring of hatchery smolts. Continue to relate physiological parameters measured with hatchery rearing practices.

2. FY 1992: Complete monitoring of smolt quality parameters.

3. FY 1993.1996: Recovery of adult returns.

4. Fy 1996: Recovery of adult fish complete; final report written. 
Coded-Wire Tag Evaluation of Missing Hatchery Groups - USFWS

Proiect of ficer: J, Bauer

\section{$\frac{\text { Results/Conclusions: Al I }}{\text { FY } 1990 \text { have been tagged. }}$}

Obiectives:

1. Identify missing production groups of salmon for Columbia River hatcheries.

2. Recover, decode and record survivability data.

3. Evaluate hatchery production programs.

Coded-Wire Tag Evaluation of Missing Hatchery Groups - WDF

Project officer: J. Bauer

\section{Obiectives:}

1. Identify missing production groups of salmon for Columbia

River hatcheries.

2. Recover, decode and record survivability data.

3. Evaluate hatchery production programs.
PRO]ECT STATUS

\section{Date Initiated: November 1989}

Date Initiated: September 1989

Results/Conclusions: All fish groups scheduled for tagging in 1989.91 were completed. Groups for 1992 will be tagged with Fy 1991 dollars on hand.

\section{SCHEDULE AND MILESTONES}

FY 1991: Missing production groups to be tagged.

FY 1992: Missing production groups to be tagged.

FY 1993: Missing production groups to be tagged and evaluation to begin.

FY 1994: Final tagging of missing production groups while evaluation continues.

FY 1995-1996: Evaluation continues.

Fy 1991: Missing production groups to be tagged.

FY 1992: Missing production groups to be tagged.

Fy 1993: Missing production groups to be tagged and evaluation to begin.

FY 1994: Final tagging of missing production groups while evaluation continues.

FY 1995-1996: Evaluation continues. 
PROJ ECT

NUMBER

$89 \cdot 30$

Evaluation of Pre-Release

Temperature Acclimation at

"Ground Water" Hatcheries - WDF

Proiect officer: A. Ruger

Obiectives:

1. To provide KIickitat River

acclimation water to the Klick-

i tat Hatchery site.

2. Compare the performance

(survival of adults to hatchery

rack) of spring chinook smolts

raised in and released directly

from a groundwater supplied

hatchery to smolts released from

the same hatchery following ac.

climation with the ambient

tributary receiving water for a

period of time before release.

Spring Chinook Smolt Quality

Assessment - NMFS

\section{Proiect officer: R. Austin}

\section{Obiectives:}

1. Select and monitor fish quality at four hatcheries.

2. Correlate these data with

overall survival of the re.

Date Initiated: February 1989

Results/Conclusions:

1. Sampling during the first two years at four hatcheries indicated that most fish were released prior to the initiation of the smoltification process.

2. Significant differences were noted in upriver vs, downstream hatchery re. leased groups (total contribu- leases in degree of smoltification.

tion).

3. Determine suitability of 3. Sampling is continuing.

smolt quality indices and

other physiological parameters 4. Developed plan for monitoring physfor assessing fish quality and iological parameters of wild smolts.

i mproving hatchery effective.

ness.

\section{SCHEDULE AND MILESTONES}

1. July 1, $1989-$ Dec. 30, 1990: Feasibility and engineering studies and construction to provide river water to the hatchery site.

2. September 1990: Start coded-wire tag fish for 4 years.

3. August 1992: start sampling coded-wire tags for 5 years.

4. June 30, 1998: Final report and project completion.
1. Fy 1991: Continue to characterize physiological parameters for hatchery spring chinook in at least three subbasins; upon approval, initiate monitoring of hatchery smolts. Continue to relate physiological parameters measured with hatchery rearing practices.

2. FY 1992: Complete monitoring of smolt quality parameters.

3. FY 1993.1996: Recovery of adult returns.

4. Fy 1996: Recovery of adult fish complete; final report written. 
PROJ ECT

NUMBER

89.65

Coded-Wire Tag Evaluation of Missing Hatchery Groups - USFWS

Proiect officer: J. Bauer

Obiectives:

1. Identify missing production groups of salmon for columbia

River hatcheries.

2. Recover, decode and record

survivability data.

3. Evaluate hatchery production programs.

89.66

$\overrightarrow{\mathrm{g}}$ Missing Hatchery Groups - WDF FY 1990 have been tagged.

\section{PROJECT STATUS}

Date Initiated: November 1989

Results/Conclusions: All groups for
Coded-Wire Tag Evaluation of

Proiect officer: J. Bauer

\section{Obiectives:}

1. Identify missing production groups of salmon for Columbia River hatcheries.

2. Recover, decode and record survivability data.

3. Evaluate hatchery production programs.
Date Initiated: September 1989

Results/Conclusions: All fish groups scheduled for tagging in 1989.91 were completed. Groups for 1992 will be tagged with FY 1991 dollars on hand.

\section{SCHEDULE AND MI LESTONES}

FY 1991: Missing production groups to be tagged.

FY 1992: Missing production groups to be tagged.

FY 1993: Missing production groups to be tagged and evaluation to begin.

Fy 1994: Final tagging of missing production groups while evaluation continues.

FY 1995-1996: Evaluation continues.

FY 1991: Missing production groups to be tagged.

FY 1992: Missing production groups to be tagged.

FY 1993: Missing production groups to be tagged and evaluation to begin.

Fy 1994: Final tagging of missing production groups while evaluation continues.

FY 1995.1996: Evaluation continues. 
PROJECT

NUMBER

89.97

cont.
TITLE

Proiect officer: T, Vogel

\section{Obiectives:}

1. Determine the effects on naturally produced fish due to predation by hatchery fish and competition for food and space between naturally produced fish and hatchery fish.

2. Determine the effects on indigenous stock productivity that result from hatchery adults interbreeding with indigenous wild fish.

3. Determine the effects of sup. plementation with hatchery fish of indigenous stock.

89.98 Determination of Effectiveness of supplementation strategies and Assessment of Interaction between supplemental Hatchery Chinook Salmon on Natural

Populations in the Salmon, Snake, and $\mathrm{Cl}$ earwater Rivers in

Idaho - IDFG

Proiect officer: T, Vogel

Obiectives:

1. Determine the effects of outplanting different life stages

of spring and summer chinook

on natural fish production.
Date Initiated: September 1989

Results/Conclusions: None at this time.
1. June 1990: Review experimental design and management agreements.

\section{October 1991: Start Phase II, Experimentation.}


PROJECT

NUMBER

TI TLE

89.98 2. Determine effectiveness of

cont. supplementation in building self-

sustaining natural runs of the

species.

3. Develop guidelines for future

supplementation in terms of size

and $t i m e$ of release.

$90-52$

Performance/Stock Productivity

I mpacts of Hatchery Supple.

Exoected Start Nata: FY 1991

FY 1991: Start project.

mentation - USFWS

Results/Conclusions: None at this time.

Proiect officer: T, Vogel

Obiectives: Develop generically

applicable model using ap.

propriate fish stock.

$90-53$

Southeast Washington species

Exoected Start Date: FY 1991

FY 1991: Start project.
Interaction study - WDW

Proiect officer: T. Voge

Obiectives:

1. Determine inter-specific

and intra-specific competition

and predation among spring

chinook, summer steelhead, and

resident trout.

2. Determine magnitude and

i mpact of residualization on

wild stocks and supplementation

programs.
Results/Conclusions: None at this time. 
PROJ ECT

NUMBER

89.97

cont

\section{Proiect officer: T. Vogel}

\section{Obiectives:}

1. Determine the effects on naturally produced fish due to predation by hatchery fish and competition for food and space between naturally produced fish and hatchery fish.

2. Determine the effects on indigenous stock productivity that result from hatchery adults interbreeding with indigenous wild fish.

3. Determine the effects of sup. plementation with hatchery fish

of indigenous stock.

Determination of Effectiveness of Supplementation Strategies and Assessment of Interaction between supplemental Hatchery Chinook Salmon on Natural

Populations in the Salmon, Snake, and $\mathrm{Cl}$ earwater Rivers in Idaho - I DFG

\section{Proiect officer: T. Vogel}

\section{Obiectives:}

1. Determine the effects of outplanting different life stages

of spring and summer chinook

on natural fish production.
Date Initiated: September 1989

Results/Conclusions: None at this time.
1. June 1990: Review experimental design and manament agreements. 
PROJ ECT

NUMBER

89.98 2. Determine effectiveness of

cont. supplementation in building selfsustaining natural runs of the species.

3. Develop guidelines for future supplementation in terms of size and time of release.

$90-52$

Performance/stock Productivity

Expected Start Date: FY 1991

FY 1991: Start project.

Impacts of Hatchery supple.

Results/Conclusions: None at this time.

Proiect officer: T. Vogel

Obiectives: Develop generically applicable model using ap.

propriate fish stock.

$90-53$

\section{Southeast Washington species}

Interaction Study - WDW

Proiect officer: T. Vogel

\section{obiectives:}

1. Determine inter-specific

and intra-specific competition

and predation among spring

chinook, summer steelhead, and resident trout.

2. Determine magnitude and

i mpact of residualization on

wild stocks and supplementation

programs.

\section{Expected Start Date: FY 1991}

FY 1991: Start project. 
PROJ ECT

NUMBER

$88 \cdot 160$

(cont.)

Project officer: A. Ruger

Objectives:

1. Rear spring chinook under

experimental conditions;

tag fish; monitor fish

healt h/ quality.

2. Recover and decode tags

for returning adults.

3. Analyze and summarize

all data.

4. Transfer technol ogy

to user groups.

5. Write final report.

88.163 Effects of Coded-Wire

Tagging on the Survival

of Spring Chinook Salmon - WDF

Proiect officer: A. Ruger

Obiectives:

1. Mark entire production of each of three hatcheries with

otolith marks and mark a

portion of the production with coded-wire tags.

2. Repeat procedure for three brood-years at each facility.

3. Determine difference in

survival rates between coded-

wire tagged and untagged groups
Date Initiated: January 1, $1989 \quad$ 1. October 1991: Begin otolith marking of third brood year fish.

Results/Conclusions: Second brood year 2. September 1993: Begin sampling fish were otolith marked in winter otoliths from adults.

1990.91. Coded-wire tagging of first year fish completed.

3. June 30, 1997: End of project; final report completed. 
PROJ ECT

NUMBER

89.69

Coded-Wire Tag Evaluation of Missing Hatchery Groups - ODFW

Proiect officer: J. Bauer

Obiectives:

1. Identify missing production groups of salmon for Columbia

River hatcheries.

2. Recover, decode, and record survivability data.

3. Evaluate hatchery production programs.

89.81.3 Modeling Optimized Hatchery Production - OSU

Proiect officer: R. Austin

Obiectives:

1. Develop a computerized

model for defining and solving

the problems of optimizing

hatchery production of anadromous sal monids.

2. Test the model by applying

to actual hatchery situations.

3. Calibrate and apply the model

to specific hatcheries.

4. Use model as a tool towards optimizing the hatchery pro. duction system and to identify areas where further research is necessary.

\section{PROJECT STATUS}

Date Initiated: September 1989

Results/Conclusions: All fish groups scheduled for tagging in 1989.91 were completed. Groups for 1992 will be

tagged with Fy 1991 dollars on hand.
Date Initiated: September 1989

Results/Conclusions:

1. Contacts established with fisheries. agencies and Tribes to form a project task force of hatchery biologists to assist in the development and testing of the hatchery model.

2. Prototype model developed and test. ing of model initiated at selected hatcheries.

\section{SCHEDULE AND MILESTONES}

FY 1991: Missing production groups to be tagged.

FY 1992: Missing production groups to be tagged.

FY 1993: Missing production groups to be tagged and evaluation to begin.

Fy 1994: Final tagging of missing production groups while evaluation continues.

FY 19951996: Evaluation continues.

1. 1991: Continue model development; prototype model available for testing and refinement.

2. 1992: Model fully developed, tested and refined; final product will include full documentation of software. Workshop training session for potential users of hatchery model will be scheduled by contractor.

III. NEW PROIECTS 


\section{COMPLETED PROJECTS}

None.

11. FY 1991 ONGOI NG PROJECTS

PROJ ECT

NUMBER

89.96

ज़

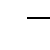$$
\text { TI TLE }
$$

A Genetic Monitoring and Evalua. tion Program for Supplemental

Populations of $S$ almon and

Steelhead in the Upper

Col umbia River Basin - NMF $S$

Proiect officer: T, Vogel

Obiectives:

1. Evaluate the nature and

extent of genetic changes in

hatchery stocks to be used for

supplementation.

2. Quantify the genetic impact

of supplementation on targeted

natural stocks and non-targeted wild stocks.

$89 \cdot 97$

Supplementing I mnaha River

Summer steelhead with Hatchery- Results/Conclusions: None at this time.

Reared Smolts and Assessment of

PROJECT STATUS

Date Initiated: September 1989

Results/Conclusions: None at this time.

\section{SCHEDULE AND MILESTONES}

September 1992: Evaluate Project and determine desirability to continue.
1. June 1991: Review experimental design

and management agreements.

2. October 1991: Start Phase II, Experimentation.

Performance, Life History

Characteristics, and Genetic

Characteristics - ODFW 
PROJ ECT

NUMBER

$90-55$

Effectiveness of Supplementa-

tion Strategies and Assessment

of Interactions Between

Wi I d/Natural and Hatchery

St ocks of summer steelhead

in Idaho - IDFG

Project officer: T. Vogel

Obiectives: Evaluate existing

supplementation programs for

stock performance character.

istics.

III. NEW PROJECTS

None.
PROJECT STATUS

SCHEDULE AND MILESTONES

\section{Expected Start Date: FY 1991}

FY 1991: Start project

\section{Results/Conclusions: None at this time.}


6.3 DATA COLLECTION FOR HATCHERY DATA BASE

(Fund in Response to System Monitoring and Evaluation Work Group Proposals)

206(e)(1) Hatchery Data Base. BPA shall fund collection of Columbia River Basin hatchery data for anadromous fish. Data to be collected, format, and schedules shall be determined by the work group on i mproving hatchery production (described aboves, working in conjunction with the work group on system monitoring and evaluation (described aboves. These data shall include, at a mi nimum: numbers of returning adults; disposition of returning adults; source and description of brood stock; actions taken to maintain genetic diversity; and size, location, and time of release of juvenile fish. Data collected shall be stored in the council's anadromous fish data base.

ACTI ON ITEM ACTIVITY SUMMARY:

Objectives:

To develop and implement the Hatchery Data Base.

Background and Progress to Date:

The scoping of the CIS in Fy 1990 and 91 (Project 88.108.1) will provide overall guidance for development of the Hatchery Data Base, as well as the Natural Production Data Base.

Plans:

The Hatchery Data Base was designed as part of the CIS project in 1990 (Project 88-108.1).

Projects:

None at this time. 
6.4 DATA COLLECTION FOR NATURAL PRODUCTION DATA BASE

(Fund in Response to System Monitoring and Evaluation Work Group Proposals $>$

206(e)(2) Natural Production Data Base. BPA shall fund collection of information on the natural production of anadromous fish in the Col umbia River Basin. Data to be collected shall include, at a mi nimumi adult escapement, redd counts, and juvenile migration for key index streams in the Columbia River Basin. The key index streams shall be consistent wi th any key index streams identified through the U.S. / Canada Pacific Sal mon Treaty and other planning processes. Data collected shall be stored in the Council's anadromous fish data base.

ACTI ON I TEM ACTIVITY SUMMARY:

Objectives:

To develop and implement the Natural Production Data Base.

Background and Progress to Date:

The scoping of the CIS in Fy 1989 (Project 88.108.1) provided overall guidance for development of the Natural Production Data Base, as well as the Hatchery Production Data Base. IDFG has the lead in coordination and development of the Natural Production Data Base Technical Work statement by the Council's MEG. No work on development planned during Fy 1990.91. CIS will be designing the data base during FYs 1991 and 1992.

Plans:

Following approval of the Work Statement by the MEG and CBFWA, BPA may be asked to fund a Natural Production Data Base project in FY 1992 .

Projects:

None at this time. 
6.5 HIGH PRIORITY PROJECTS IN AREAS OF EMPHASIS

(Fund Only These in Fy 1987)

$206(b)$

[Abstract] This measure directs BPA to focus its funding of sal mon and steel head research in the next five years in the four areas of emphasis.

ACTI ON ITEM ACTIVITY SUMMARY:

Objectives:

To fund only high priority projects in the areas of emphasis during FY 1987 .

Background and Progress to Date:

One project, a demonstration of a system for removing malachite green from hatchery effluent (Project 87-421), was identified by the agencies and Tribes as sufficiently important to merit priority funding in FY 1987. The FDTWG strongly supported this project and requested that it be funded i mmediately. BPA initiated Project 87.421 in FY 1987; the project was completed in Fy 1989.

Plans:

Action ltem 6,5 has been completed.

Projects:

None. 
6.10 SYSTEM MONITORING AND EVALUATION

( Coordinated Information System>

206(d)(2)(c) [Abstract] The council's system monitoring and evaluation program will include development of a coordinated information system designed to facilitate effective exchange and dissemination of fisheries data.

ACTI ON I TEM ACTIVITY SUMMARY:

Objectives:

To fund development and operation of SMEP.

Background and Progress to Date:

In FY 1988, BPA began funding Project 88.108.1 to develop the CIS to contribute to the SMEP. Projects 88.108.2 and 89.104 began in FY 1989 .

Plans:

BPA will continue to fund the three ongoing projects through completion. 
1. COMPLETED PROJECTS

None.

11. FY 1991 ONGOING PROJECTS

PROJECT

NUMBER

88.108.1 Coordinated Information System (CIS) - PSMFC

Project of ficer: M. Schneider

\section{Obiectives:}

1. Select project team

2. Conduct project orientation

3. Complete watershed classifi.

cation final report (Phase II).

4. Complete CIS data catalogs.

Includes those prepared under

Natural Production Data Base,

Hatchery Production Data Base, and Habitat/Land Use Data Base objectives as well as other data bases (Phase II).

5. Complete CIS Technical Report, Project Work PIan for Phase III, and Stock Assess. ment Report (Volumes I and II) (Phase I and II).

6. Complete prototype design and testing (Phase III).
Date Initiated: January 1989

Results/Conclusions: Objectives 1 and 2 FY 1992: (Spring 1992) Complete Phase II. are completed. CIS Team has provided

guidance for development of description FY 1993.94: Complete Phase III. of work for stock assessment updates,

the Hatchery and Natural Production Data Bases, and a I and use/habitat data base.

SCHEDULE AND MILESTONES

FY 1990: Complete Phase I. 
PROJECT

NUMBER

88.108.2 EPA/USGS Mapping System for Northwest Envrionmental Database (NED) and Coordinated

Information System (CIS) - USCS

Proiect officer: T. Pansky

Obiectives:

1. Complete regional digital

hydrographic data base at

$1: 100,000$ scale for use in NED

and $\mathrm{CIS}$.

2. Enhance current EPA/USGS

mapping system.

89.104 Historical Data Base

- USFS/PNWRS

Proiect officer: M. Schneider

Obiectives: Archive summaries and $r$ aw data from original

Bureau of Fisheries habitat

surveys of the Columbia River

and tributaries. Publish

summaries in book form by sub-

basin

III. NEW PROJECTS

None.
Date Initiated: October 1989

Results/Conclusions: Basic system is complete for states of Washington, Oregon, Idaho, and western Montana.

Date Initiated: FY 1989

Results/Conclusions: None at this ti me.
FY 1991: Complete portions of Nevada, Utah, and Wyoming within Columbia River Basin and select Missouri River Basin subbasins in Montana. Arrange for regional maintenance and distribution.

Fy 1990: Microfiche original field notes and prepare notes for data base manament system.

FY 1990 to FY 1993: Produce a data base manage. ment system for historical stream inventories which is integrated with cls protocols for subbasin stream inventory data. Edit and produce Columbia Basin stream inventory for areas above and below Bonneville Dam.

Fy 1993: Project scheduled for completion. 
COORDINATION ACTION ITEMS 
6.12

(By All Federal Project Operators/Regulators)

1203(c) [Abstract] The Federal project operators and regulators shall work with the agencies and Tribes to comply with the consultation/coordination requirements of the Act. The Council expects research planning consultation to occur among agencies, Tribes, and project operators and regulators. The Council will encourage improved coordination of fish and wildlife efforts by consulting with the fish and wildlife agencies, Tribes, project operators and regulators, BPA customers, Federal and state water and Iand management agencies, irrigation districts, academic experts, and interested citizens groups.

\section{ACTI ON ITEM ACTIVITY SUMMARY:}

\section{Objectives:}

To provide for the involvement of the region's fish and wildlife agencies and Tribes at relevant decision-making points while BPA plans its implementation of the Program and to improve coordination and consistency between BPA's implementation actions and the agencies' and Tribes' existing and future management activities.

\section{Background and Progress to Date:}

In early April 1987, BPA staff began meeting with Council staff and an ad-hoc committee of CBFWA. The meetings focused on explaining BPA's process for implementing the Program, from project inception through completion. Participants agreed to continue discussion, with a goal of developing a collaborative and cooperative process through which BPA would plan and implement the Program. As a result of these discussions, an Implementation Planning Process (IPP) was developed jointly by CBFWA and BPA (see section III of the AIWP).

The IPP was endorsed by the BPA Administrator and the CBFWA Chair on October 19, 1988. The IPP's Policy Review Group (PRG) was formed in late 1988, In January 1989, the PRG began providing BPA with policy and funding recommendations related to Program implementation. The PRG continues to serve as a forum for policy coordination and consultation among BPA, fish and wildlife agencies, Tribes, utility interests, council, and other interested parties. The Al WP is based on the outline developed by the PRG during step 1 of the annual IPP cycle.

Plans:

BPA plans to continue to use the IPP as a coordination and consultation mechanism and to develop the AIWP. 
RESIDENT FISH ACTION ITEMS AND TECHNICAL SUBJECTS 
7.1 COLVI LLE HATCHERY

(Complete Construction: March 1989)

(Fund Operation and Maintenance)

$903(g)(1)(A)$ [Abstract] Design, construction, operation and maintenance of a resident trout hatchery on the Colville Indian Reservation. The Council expects that state-of-the-art technologies will be used in the design of the hatchery.

ACTI ON ITEM ACTIVITY SUMMARY:

Objectives:

To design and construct a resident trout hatchery on the colville Indian Reservation to mi tigate partially for anadromous fish losses from hydroelectric development and operation.

Background and Progress to Date:

The primary purpose of the hatchery is to produce trout to stock lakes and streams on the Reservation. The Colville confederated Tribes (CCT) constructed the hatchery through subcontracts. The final design for the hatchery was completed in october 1987.

Construction began in July 1988 and was completed in fall 1989. Operations began in october 1989. The hatchery met its production and release goals for year one (FY 90) operations.

Plans:

BPA will continue to fund the operation and maintenance of the facility by the CCT. Year two (FY 91) operations are funded and under way. 
1. COMPLETED PROJECTS

None.

II. FY 1991 ONGOING PROJECTS

PROJ ECT

NUMBER

$85 \cdot 38$

Colville Hatchery - CCT

Proiect officer: J, Marcotte

Objectives: Design and

construct a resident trout ery on the colville Indian hatchery in September 1989.

Reservation. initiated July 1988. Completed construction of 50,000 pound trout
PROJECT STATUS

Date initiated: 1985

III. NEW PROJECTS

None

SCHEDULE AND MILESTONES

Continuing: Started operation and maintenance in October 1989. O\&M to continue.

Results/Conclusions: Design completed in FY 1987. Construction contract 
7.2 COEUR D'ALENE RESERVATI ON ACTI ONS

(Fund Stream Survey; Design, Construction, Operation, and Maintenance of Cutthroat/Bull Trout Hatchery; Habitat I mprovement Projects;

3. Year Monitoring Program)

$903(\mathrm{~g})(1)(B)$ [ Abstract] BPA shall fund a baseline stream survey of

tributaries located on the Coeur d'Alene Indian Reservation to compile information on improving spawning habitat, rearing habitat, and access to spawning tributaries for cutthroat and bull trout, and to evaluate the existing fisheries. If justified by the results of the survey, fund the design, construction, and operation of a cutthroat and bull trout hatchery on the Coeur d'Alene Reservation; necessary habitat improvement projects; and a three-year monitoring program to evaluate the effectiveness of the hatchery and habitat improvement projects. If the baseline survey indicates a better alternative than construction of a fish hatchery, the coeur d'Alene Tribe will submit an alternative plan for consideration i n program amendment proceedings.

ACTION ITEM ACTIVITY SUMMARY:

Objectives:

Survey the streams on the Coeur d'Alene Indian Reservation for status of stocks and the possibility of improving habitat. If feasible, construct habitat improvement projects. Determi ne need for stock supplementation and, if needed, fund design, construction, and operation of a cutthroat and bull trout hatchery.

Background and Progress to Date:

Not applicable.

Plans:

BPA plans to fund this Action Item, beginning in Fy 1990 with a project to conduct the stream surveys. 
1. COMPLETED PROJECTS

None

\title{
11. FY 1991 ONGOING PROJECTS
}

PROJECT

NUMBER

90-44 Stream Survey, Hatchery,

I mprovements, and Monitoring

on the Coeur D'Alene

Reservation

Proiect officer: R. Austin

\section{Obiectives:}

1. Survey streams and determi ne stock status.

2. Assess possibilities for

habitat improvement.

3. Construct hatchery, if needed.

4. Monitor results of habitat

i mprovement projects and hatchery

suppl ement ation.

PROJECT STATUS

Date Initiated: September 1990

Results/Conclusions:

1. Initial stream survey by aircraft completed in December 1990 using BPA helicopter and pilot.

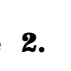

\author{
.
}


7.3 KOKANEE SALMON HATCHERIES

(Fund Design, Construction, Operation, Maintenance of Hatcheries at Galbraith Springs and Sherman (reek: Begin FY 1988.)

(Fund Monitoring Programs)

$903(g)(1)(C)$ [Abstract] BPA shall fund design, construction, operation, and maintenance of two kokanee sal mon hatcheries, one at Galbraith springs and one at sherman creek. The Sherman Creek hatchery will be used as an imprinting site and egg collection facility to provide a source of kokanee fry for: i) stocking into Banks Lake and i i) transferring to Galbraith springs hatchery for rearing to fingerling size before planting into Lake Roosevelt. Decisions on hatchery production, stocking, and outplanting locations will be coordinated by a three-member committee consisting of one representative each appointed by the colville Confederated Tribes, spokane Tribe, and the Washington Department of Wildlife.

\section{ACTION ITEM ACTIVITY SUMMARY:}

Objectives:

To fund the design, construction, operation, and maintenance of two kokanee salmon hatcheries.

Background and Progress to Date:

Preliminary design began in Fy 1988.

Pl ans:

Construction will be completed and O\&M will begin in FY 1991. 
1. COMPLETED PROJECTS

PROJ ECT

NUMBER

\section{TITLE}

$90-76$

Hatchery Manager Training

Program - Spokane Tribe

Proiect officer: S. Levy

Obiectives:

1. Provide advanced training

for kokanee hatchery manager.

2. Write a hatchery management

plan.

3. Provide on-site inspection

during hatchery construction.

$\ddot{\Phi}$

$88 \cdot 62 \cdot 3$

Construct Hatchery Residence Galbraith Springs

Proiect officer: S. Levy

Obiectives: Provide housing

for hatchery manager.

90.86

Sherman Creek Hatchery

Proiect officer: S. Levy

Obiectives: Construct kokanee hatchery.

\section{PROJECT STATUS}

Date Completed: December 1990

Results/Conclusions: Training program was completed satisfactorily.
Date Completed: April 1991

Results/Conclusions: Construction completed in April 1991.

Expected Completion Date: June 1991

Results/Conclusions: Construction to be completed in June 1991. 
11. FY 1991 ONGOING PROJECTS

PROJ ECT

NUMBER

88.62

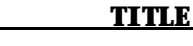

Spokane Tribal Fish Hatchery Galbraith springs

Proiect officer: S. Levy

Obiectives: Design, construct, and operate kokanee hatcheries.

91.46

Spokane Tribal Hatchery O\&M

- Spokane Tribe

Proiect officer: S. Levy

Objectives: Operate and maintain kokanee hatchery to

provide a recreational fishery

in Lake Roosevelt and Banks

Lake. In conjunction with

the Sherman Creek Hatchery.

91.47 Sherman Creek Hatchery O\&M - WDW

Project officer: S. Levy

Obiectives: Operate and main.

tain facility to provide

kokanee for Lake Roosevelt

and Banks Lake.
PROJECT STATUS

Date Initiated: FY 1988

Results/Conclusions: None.

Date Initiatedi January 1991

Results/Conclusions: Start-up of hatchery operations has been successfully begun.

Expected Start Date: June 1991

Results/Conclusions: None at this time.
SCHEDULE AND MILESTONES

FY 1991: Complete final design and Galbraith springs Hatchery construction.

FY 1991: Complete construction of Sherman creek facility.

FY 1991: Begin 08M.

FY 1991: Begin O\&M.

III. NEW PROJECTS

None. 
7. 4 HABITAT AND PASSAGE I MPROVEMENTS ON LAKE ROOSEVELT TRIBUTARY STREAMS

(Fund Design, Construction, Operation, Maintenance of Projects: Begin Fy 1989)

(Fund Monitoring Programs).

$903(\mathrm{~g})(1)(D)$ [ Abstract] BPA shall fund capital, operation, and maintenance of pilot projects for improving habitat and passage into and out of Lake Roosevelt tributary streams for rainbow trout. The aim of this measure is to emphasize natural production by: i) facilitating passage of migratory rainbow trout bet ween Lake Roosevelt and its tributary streams and $i j$ ) improving fry and fingerling rearing habitat in these streams.

$903(\mathrm{~g})(1)(E)$ [Abstract] Monitoring to eval uate the effectiveness of the above measures.

ACTION ITEM ACTIVITY SUMMARY:

Objectives:

To i mprove stream habitat and passage into and out of Lake Roosevelt tributary streams for rainbow trout. Determine status of fish stocks in Lake Roosevelt before habitat improvements and hatchery construction. Evaluate the contribution of the hatcheries and habitat improvement projects of stocks in Lake Roosevelt.

Background and Progress to Date:

BPA funded a stock assessment study in Fy 1988. Monitoring program started in summer of 1988 .

PI ans:

BPA will continue to fund habitat improvement projects in Fy 1992. Annual reports on monitor ing are available. 


\section{COMPLETED PROJECTS}

None.

\section{FY 1991 ONGOING PROJECTS}

PROJ ECT

NUMBER

88.63 Lake Roosevelt Monitoring Program - Spokane Tribe

Project officer: F. Hol m

Obiectives:

1. Determine status of fish

stocks in Lake Roosevelt before

construction of habitat

i mprovement projects and

hatcheries.

2. Evaluate contribution of

these projects and hatcheries

to Lake Roosevelt.

Lake Roosevelt Habitat

I mprovement Projects - CCT

Project officer: S. Levy

Obiectives: Facilitate passage of resident fish in Lake Roose. velt tributaries and improve

rearing habitat.
PROJECT STATUS

Date Initiated: July 1988

Results/Conclusions: Available in annual reports.
Date Initiated: April 1990

Results/Conclusions: None at this time.
FY 1991: Continue habitat assessment and develop work plan.

FY 1992 and 1993: I mplement i mprovements from work plan developed in Fy 1991. Lake Roosevelt and measure the success of habitat i mprovement projects and hatcheries.

2. FY 1995: Project scheduled for completion.

III. NEW PROJECTS

None. 
7 KOOTENAI INDIAN RESERVATI ON STURGEON HATCHERY

(Fund Design, Construction, Operation, Maintenance of Hatchery: Begin FY 1988)

(Fund Evaluation Study>

903(g)( 1$)(H)$ [Abstract] BPA shall fund design, construction, operation and maintenance of a low-capital sturgeon hatchery on the Kootenai Indian Reservation. BPA and the Kootenai Tribe also shall explore alternative ways to make effective use of the hatchery facility year-round.

ACTI ON ITEM ACTIVITY SUMMARY:

Objectives:

To design, construct, and operate a low-cost experimental sturgeon hatchery on the Kootenai Reservation in Idaho.

Background and Progress to Date:

Project was funded to develop a water supply, design a hatchery, and train personnel in sturgeon culture in FY 1990. Ground water was found to be unsuited for fish production - City of Bonners Ferry water mi xed with Kootenai River water will be used. Hatchery completed in spring of 1991.

PI ans:

BPA has funded project as stated above. Hatchery was constructed and operational in spring of 1991. 
1. COMPLETED PROJECTS

None.

11. FY 1991 ONGOING PROJECTS

PROJECT

NUMBER

88.64

Design, Construct, and

Operate a sturgeon Hatchery

on the Kootenai Reservation,

Idaho - Kootenai Tribe

Project of ficer: F. Hol m

Obiectives: Same as title.
PROJECT STATUS

Date Initiated: September 1988

Results/Conclusions ed FY 1991 .
SCHEDULE AND MILESTONES

FY 1991: Construction has started and will be completed in Fy 19g1. Hatchery is scheduled to be in operation in spring of 1991.

FY 1992: Continue hatchery operations.

111. NEW PROJECTS

None. 
7.6 STURGEON AND WATER LEVEL FLUCTUATIONS: I DAHO PORTION OF KOOTENAI RI VER

(Fund Study to Assess I mpacts: Begin FY 1989)

$903(g)(1)(I)$ [Abstract] BPA shall fund a survey of the Kootenai River downstream from Bonners Ferry, Idaho, to the Canadian border to: i) evaluate the effectiveness of the hatchery and ii) assess the i mpact of water level fluctuations caused by Libby Dam on hatchery operation for outplanting of sturgeon in the Idaho portion of the kootenai River.

ACTION ITEM ACTIVITY SUMMARY:

Objectives:

To assess the status of sturgeon stocks in the Kootenai River; obtain brood fish for hatchery; assess the impact of water level fluc. tuations caused by Libby Dam.

Background and Progress to Date:

BPA has funded a project with IDFG to begin looking for broodstock and train hatchery personnel. Project began in late Fy 1988. Sturgeon have been caught and tagged and are being monitored. Broodstock were spawned in spring of 1991.

Plans:

BPA will continue to fund this study in Fy 1992, with emphasis directed toward obtaining brood fish for the hatchery and rearing sturgeon for stocking in Kootenai River. Stocked sturgeon will be tagged and their movements monitored. 
1. COMPLETED PROJECTS

None.

11. FY 1991 ONGOING PROJECTS

PROJ ECT

NUMBER

$88 \cdot 65$

Assess I mpacts of Water Level

Fluctuations on Sturgeon in

the Kootenai River = IDFG

Project of ficer: F. Hol m

Qbiectives: Assess status of sturgeon stocks in the Kootenai River and effects of water

fluctuations on these stocks.

obtain brood fish for hatchery.

\section{PROIECT STATUS}

Date Initiated: September 1988

Results/Conclusions: BPA contracted

with IDFG to conduct this study

beginning in 1988, Sturgeon are being

caught, tagged and monitored. Broodstock

for experimental rearing were obtained

for 1991 and 1992.

11. NEW PROJECTS

None. 
7.7 PEND OREILLE RI VER FI SHERY I MPROVEMENTS ON KALI SPEL RESERVATI ON

(After Council Consultation, Fund Assessment of Improvement

opportunities: Begin Fy 1988)

$903(\mathrm{~g})(1)(G)$ [Abstract] BPA shall f und an assessment of fishery improvement opportunities in the Pend Oreille River within the boundaries of the Kalispel Indian Reservation. This survey will provide: i) baseline information about existing fish populations and habitat and ij) information on possible means of improving fisheries. Upon completion of the assessments, recommendations for fisheries projects will be submitted to the council.

\section{ACTION ITEM ACTIVITY SUMMARY:}

Objectives:

To survey the fish populations in the Pend Oreille River within the boundaries of the Kalispel Reservation. Develop recommendations to i mprove the fisheries.

Background and Progress to Date:

Project began in February 1988. Baseline data of fish stocks and angler use are in annual reports printed in 1989 and 1990 . Project was completed in June 1991.

PI ans:

Recommendations for fisheries improvement alternatives will be submitted to the council. 
1. COMPLETED PROJECTS

PROJ ECT

NUMBER

$88-66$

Assess Fishery I mprovement Options in the Pend Oreille

River - KIT

Project of ficer: F. Hol m

Objectives: Survey fisheries

in the Pend Oreille River.

Develop recommendations to

i mprove the fisheries.

11. FY 1991 ONGOING PROJECTS

None.

III. NEW PROJECTS

None.
PROIECT STATUS

Date Comoleted: June 1991

Results/Conclusions: Recommendations to i mprove the fisheries are contained in

Final Report. They will be referred to the council for further action. 
903(g)(2) [Abstract] The appropriate party or parties shall fund resident fish substitution actions in the blocked area above Hells Canyon Dam to partially mi tigate for salmon and steel head losses incurred as a result of the construction and operation of Federal and non-Federal hydropower projects in the blocked area.

\section{ACTI ON I TEM ACTIVITY SUMMARY:}

\section{Objectives:}

Develop funding mechanisms and scheduling for resident fish substitution projects above Hells Canyon Dam.

Background and Progress to Date:

BPA has agreed to fund a portion of the Duck Valley measure. Trout were purchased from private growers and stocked in Fy 1988 through FY 1991. BPA funded a study to develop alternative means to annual fish stocking to enhance the fisheries of the Reservation and the development of a fisheries management plan.

Plans:

Trout will be purchased and stocked on the Duck Valley Reservation in FY 1992 .

BPA assisted in a feasibility study for resident fish artificial production above Hells Canyon Dam in FY 1991. Funding of this feasibility study does not represent agreement by BPA to fund additional resident fish substitution projects above Hells Canyon Dam prior to the determination of the appropriate funding entity, or entities, by the council. 
1. COMPLETED PROJECTS

None

11. FY 1991 ONGOING PROJECTS

PROJ ECT

NUMBER

$88 \cdot 156$

Duck Valley Resident Fish

Project - SPT

Proiect officer: F, Hol m

Objective: Purchase rainbow trout to stock waters on Duck Valley Reservation and i mple. ment a management plan for reservation waters.

Feasibility Study - Hatchery Production Above Hells Canyon

Proiect officer: F, Hol m

Objectives: Determine the costs, feasibility, and advan. tages of expanding capacity I construction of new raceways, collection of additional water from wells or springs, install. ation of oxygen injection, or additional staffingl at Ashton, Cabinet Gorge, Hayspur, Mackay,

or Nampa hatcheries to meet fish
PROJECT STATUS

Date Initiated: FY 1988

Results/Conclusions: The project funded the purchase of fingerling and catchable rainbow trout for stocking in waters on on the Duck Valley Reservation and the development of a fisheries management plan.

Expected Start Date: FY 1991

Results/Conclusions: None at this time

\section{SCHEDULE AND MILESTONES}

Fy 1992: The fisheries management plan will be i mplemented and trout will be purchased.

Fy 1991: Start study and complete within 12 months. 
$91 \cdot 27$

cont.

culture needs identified in Program

Section $903(\mathrm{~g})(2)$ versus con.

struction of an appropriate incu.

bation and early rearing facility

combined with lesser expansion at

one of the above hatcheries or a

USF WS hatchery.

\section{NEW PROJECTS}

PROJ ECT

NUMBER TI TLE

$92 \cdot 10$

Fort Hall Bottoms Habitat

New Project

Enhancement - Shoshone.Bannock

Tribes

Project of ficer: F. Hol m

Objectives: I mprove habitat

for cutthroat and rainbow trout

in $\mathrm{Cl} e a r$ Creek and Spring Creek

al ong the Fort Hall Bottoms on

the Fort Hall Reservation.
SCHEDULE AND MILESTONES

FY 1992: Begin improvement work in FY 92 as the

soon as a feasibility report by the Shoshone-Bannock Tribes is completed and approved. 
7.11 ONGOING STUDIES INMONTANA

(Continue Cooperative Studies; Present Results to Council.

Submit Recommendations by October 1, 1990.)

903
[Abstract] The measures referenced in the Action Item are concerned wi th the operations of Hungry Horse and Kerr dams and how their operations affect the game fish populations in the Flathead Basin. They also concern the reservoir levels of Hungry Horse and Libby and how these levels affect the game fish population in the reservoirs themselves. Operation procedures are to be recommended and mi tigation levels for fish losses determined for effects of the hydroelectric system.

\section{ACTI ON ITEMACTIVITYSUMMARY:}

\section{Objectives:}

To determine the effects of reservoir drawdown and flows on resident fish in the Flathead River Basin in order to determine how various reservoir levels affect the fish in Libby and Hungry Horse Reservoirs.

\section{Background and Progress to Date:}

These projects have been i mplemented because the resident fish resources of the Flathead Basin have been severely affected by the construction and operation of Hungry Horse and Kerr dams. In the Kootenai Basin, the resident fish resources have been similarly affected by the construction and operation of Libby Dam. The effects of reservoir drawdown and flows on the kokanee and other game fish are being determined. When projects have been completed, recommendations will be made for hydro operations and seasonal drawdown levels compatible with the needs of the fish. Mitigation plans will be developed for losses that have occurred.

PI ans:

The final reports for the projects were completed in 1989 and 1990;

BPA will submit the project results to the Council. Recommendations for future action were submitted to the Council in May 1991.

\section{Projects:}

No BPA. f unded projects. 
$903(e)(1)$

BPA shall fund research to determine the impacts of development and operation of the hydroelectric power system on sturgeon in the Columbia River Basin. These studies may include: 1) habitat requirements; 2) maintenance of genetic integrity; 3) stock assessment; 4) potential for artificial propagation; and 5) migrating potential. Specific recommendations for the protection, mitigation, and enhancement of sturgeon may be submitted to the council upon completion of these studies.

\section{ACTI ON ITEM ACTIVITY SUMMARY:}

Objectives:

To determine the impacts on white sturgeon from the development and operation of the hydropower system. Develop recommendations for the protection, mitigation, and enhancement of white sturgeon.

Background and Progress to Date:

I mpacts on white sturgeon from the development and operation of hydropower have not been determined, but there is evidence that the i mpacts have been substantial. From a series of workshops funded by BPA, a work plan for sturgeon research was developed, followed by a sturgeon research program implementation plan. These were submitted to the Council, as called for by Action Item 7,12. Two projects are currently being funded by BPA. The University of Idaho (UI) study transferred from the University of Washington will determine early I ife history requirements and the genetic makeup of the stocks throughout the Basin. The other study, a four-agency project to determine the habitat requirements and status of stocks downstream from McNary Dam, is in its fifth field season.

Plans:

The genetic identification study was expanded into the Upper Columbia Basin and the Kootenai River areas and completed in Fy 1991. A sturgeon hatchery was constructed on the Kootenai Indian Reservation. The habitat requirements and stock assessment study has been designed as a 6-year project because of the large study area and the multiple objectives involved. 
1. COMPLETED PROJECTS

PROJ ECT

NUMBER

$89 \cdot 44$

White Sturgeon Early Life History Requirements and Genetics Study - UI

\section{Project officer: F. Hol m}

Obiectives: 1. Determine whether white sturgeon are represented by genetically distinct stocks.

2. Determine the early life requirements for white sturgeon
PROIECT STATUS

Expected Comoletion Date: July 1991

Results/Conclusions: Allelic differences were identified in fish from Lake Roosevelt and the Kootenai River. Stocks from the lower Col umbia appear to be genetically similar. Behavioral patterns and food requirements for young sturgeon have been documented. Annual reports are available.

\section{FY 1991 ONGOING PROJECTS}

\section{PROJ ECT} NUMBER

$86 \cdot 50$

TITLE
Requirements of White sturgeon
Populations in the Columbia Populations in the Col umbia River Downstream from McNary
Dam - ODFW (WDF, USFWS, and NMF $S$ are subcontractors)

Project officer: F. Hol m

\section{PROJECT STATUS}

\section{Results/Conclusions:}

Collection of all age groups of

sturgeon has been successful, with

Iarval sturgeon and eggs being

collected in The Dalles and Bonneville Dam pools. Coordination with the work ongoing below Bonneville Dam is excellent.

Annual reports for 1988-DOE/BP-63584-2 and 1989-D0E/BP-63584-3 are available.

\section{SCHEDULE AND MILESTONES}

1. 1992: Model development will continue to identify effects of hydropower on population status and habitat.

2. 1992: Project is scheduled for completion.

3. 1992: Final Report will be written. 
PROJ ECT

NUMBER

86.50

cont.

Obiectives: Determine the

status and habitat requirements

of white sturgeon in the

Col umbia River downstream from

McNary Dam. Detailed objectives

and results are described in

the Project's annual reports.

11. NEW PROJECTS

None. 
MEASURE LANGUAGE:

Not applicable. Council deleted measure in amended Program.

TECHNICAL SUBJECT ACTIVITY SUMMARY:

Objectives:

To design, construct, and evaluate the Pend Oreille (Cabinet Gorge) Hatchery. Evaluate the degree to which the Albeni Falls and Cabinet Gorge projects are responsible for the decline of the Lake Pend Oreille fishery, and the level of mitigation necessary to restore a reasonable number of fish in Lake Pend Oreille.

\section{Background and Progress to Date:}

The Pend Oreille (Cabinet Gorge) Hatchery was completed in 1985. The hatchery is designed to produce 20 million kokanee fry annually to enhance the fishing of Lake Pend Oreille, which has been adversely affected by Cabinet Gorge and Albeni Falls dams and the introduction of mysis shrimp. BPA and the Washington Water Power Company shared the costs of constructing the facility. The IDFG funds the operation and maintenance of the hatchery. Evaluation activities are continuing.

Pl ans:

Fund evaluation activities through completion. 
1. COMPLETED PROJECTS

None.

II. FY 1991 ONGOING PROJECTS

PROJ ECT

NUMBER

$85 \cdot 339$

\section{Kokanee Stock Status and}

Contribution of Cabinet Gorge

Hatchery, Lake Pend Oreille,

I daho - I DFG

Project of ficer: F, Hol m

Obiectives: Determine the contribution of the Cabinet Gorge Hatchery to the kokanee fishery in Lake Pend Oreille. Detailed objectives are described in the Project's annual reports.

\section{PROJECT STATUS}

Date initiated: 1985

Results/Conclusions: Kokanee egg takes

for the hatchery have fluctuated each

year. 12 million eggs were taken

in 1990. Only 5 million in 1991.

Hatchery water problems are being solved:

flushing flows from Cabinet Gorge Dam are required to get fingerlings down the Clark Fork River into Lake Pend Oreille. I DFG continues to work with

Washington Water Power on this.

The kokanee population in pend oreille was estimated to be 10.2 million in 1990 and 7.7 million in 1991. Population continues to fluctuate, but is higher than before the hatchery began to contribute fish to the lake.

\section{SCHEDULE AND MILESTONES}

1. 1992: Water will be requested for flushing flows in July and August 19g2. Zooplankton data will be analyzed and results compared to previous years' data and related changes in kokanee densities and growth rates in order to define carrying capacity better. Some plants will be made, using a U.S. Navy barge. Creel census will be used to estimate contribution of Cabinet Gorge Hatchery.

2. Project scheduled for completion in spring of 1993.

\section{II. NEW PROJECTS}

None. 
7.13 ACCUMULATED MATERIALS IN KOOTENAI RIVER

(Initiate Removal >

$903(d)(1) \quad$ BPA shall fund the removal of materials which have accumulated in Kootenai River tributary deltas below Libby Dam as a result of the dam's construction and operation and which interfere with the migration of spawning fish.

ACTI ON ITEM ACTIVITY SUMMARY:

Objectives:

When necessary, remove materials which have accumulated in Kootenai

River tributary deltas and which interfere with fish migration.

Background and Progress to Date:

Not applicable.

Plans:

None at this time. 
$903(e)(4)$

BPA shall fund a study to assess the impacts of the original construction and current operation of Dworshak Dam on the resident fishery. This study will include the following research concerns of the Nez Perce Tribe: 1) population dynamics of kokanee; 2) reservoir productivity; 3) food habits of rainbow trout; 4) population dynamics and habitat preferences of small mouth bass; and, 5) the status of forage species. This study effort will be coordinated with the corps. Recommendations detailing specific protection, mi tigation and enhancement opportunities, consistent with the requirements of $804(e)(16)$, may be submitted to the council.

\section{ACTION ITEM ACTIVITY SUMMARY:}

\section{Objectives:}

To assess the status of resident fish stocks, particularly kokanee; to compare data to that obtained when reservoir was first filled; to determi ne whether changes are caused by operation of Dworshak Dam.

\section{Background and Progress to Date:}

Two projects have been funded to cover the five concerns listed in the Program Measure. IDFG and the NPT are the contractors for the projects. The projects started July $1,1987$.

\section{PI ans:}

The projects will run until December 31 1991, at which time IDFG and the NPT may submit recommendations detailing specific protection, mitigation, and enhancement plans to the council. 
None.

\section{FY 1991 ONGOING PROJECTS}

PROJ ECT

NUMBER

$87 \cdot 99$

\section{TITLE}

Dworshak Dam Impacts Assessment and Fisheries Investigation I DFG

Proiect officer: R. Austin

Obiectives: 1. Assess the status of kokanee stocks in the reservoir.

2. Document losses of kokanee fish in Dworshak Reservoir. through turbines at Dworshak Dam.

3. Assess li mnological parameters and evaluate impacts of reservoir management on the zooplankt on community and kokanee production.

Dworshak Reservoir Investigation: Trout, Bass and Forage Species - NPT

\section{Proiect officer: R. Austin}

Obiectives: 1. Assess the status of rainbow trout, small mouth bass, and forage species in the reservoir.

2. Assess changes in these populations in relation to reservoir management.

Date initiated: July 1987

Results/Conclusions: Kokanee abundance estimated from late June trawl data, was 540,000 fish in 1989. Anglers harvested 2. FY 1992: Prepare final report coordinated with 171,331 kokanee at 1.3 fish per hour. Project 87.407. Recommendations will be made to Creeled fish averaged $246 \mathrm{~mm}$ and $121 \mathrm{~g}$; the council for measures to protect, mitigate, and Yield was $3.1 \mathrm{~kg} / \mathrm{hr}$. Spawning escapement enhance resident fish in Dworshak Reservoir. was si milar to 1988 with 37,000 kokanee observed in five tributaries of the reservoir in mid-to-late september. Two-year old spawners $1277 \mathrm{~mm}$ total length) comprised the bulk of the run.

Date initiated: July 1987

Results/Conclusions: An estimated 152,700 angler hours were expended from March 1989 through February 1990 to catch a total of 20,426 rainbow trout, 13,064 small mouth bass, and 180 bull trout. Approximately $98 \%$ of the rainbow trout caught were of hatchery origin. Overall growth of small mouth bass is better than that reported for other small mouth bass populations at similar latitudes.

Fish production has apparently stabilized
1. Fy 1991: Continue baseline data collection.

Fy 1992: Prepare final report coordinated with Project 87.99. Recommendations will be made to the Council for measures to protect, mitigate, and enhance resident fish in Dworshak Reservoir 
PROJ ECT

NUMBER

TI TLE

87.407

cont.

111. NEW PROJECTS

None.
PROIECT STATUS

SCHEDULE AND MI LESTONES

since the extreme population fluctuations noted during the 1970's. 
( Continue Cooperative Studies; Present Results to Council, Submit Recommendations by March 1, 1988.)

903(b) (3-4) [Abstract] BPA shall fund research to develop operating procedures for Libby and Hungry Horse, including establishment of reservoir levels to protect resident fish and development of alternative means to resolve conflicts between drawdown limits and requirements for fish flows by means of the water budget. BPA shall submit results to the Council by March 1, 1988. Mitigation projects shall be identified in the Flathead Basin in relation to construction and operation of Hungry Horse. Results will be submitted to the Council by November 15, 1987.

\section{ACTION ITEM ACTIVITY SUMMARY:}

Objectives:

To determine the effects of reservoir operations on fish in Libby and Hungry Horse Reservoirs. Identify mitigation projects in the Flathead Basin in relation to construction and operation of the Hungry Horse hydroproject.

\section{Background and Progress to Date:}

Projects at Libby and Hungry Horse Reservoirs have been funded since 1983. Both projects were designed to document the effects of water level fluctuations on resident fish. The fluctuations reduce primary and secondary production in the reservoirs, hence they have a direct i mpact on fish production. Annual reports from 1983 through 1988 document these effects. Mi tigation alternatives for losses from the construction and operation of Hungry Horse Dam are described in the final report for BPA.funded Project 85.23. The models developed during the project have been critically reviewed by researchers at the University of Washington.

PI ans:

Recommendations for further action will be submitted to the council after completion of the studies. Biological models will be run concurrently with the System Analysis Model to help guide recommendations. 
None.

11. FY 1991 ONGOING PROJECTS

PROJ ECT

NUMBER

83.465
PROJECT STATUS

Date initiated: April 1, 1983

Quantification of Hungry Horse Reservoir Levels Needed to

Maintain or Enhance Reservoir

Fisheries - MDFWP

Proiect officer: D. Johnson

Objectives: 1. To study the effects of reservoir drawdown.

2. To develop a predictive model of hydro operations on resident fisheries, and recommend seasonal drawdown levels compatible with the needs of the fish.

83.467

Quantification of Libby Reservoir Levels Needed to Maintain or Enhance Reservoir Fisheries - MDFWP

\section{Proiect officer: D. Johnson}

Objectives: 1. To study the effects of reservoir drawdown. 2. To develop a predictive model of hydro operations on resident fisheries, and recommend seasonal drawdown levels
Date Initiated: April 1, 1983

Results/Conclusions: Gill net sampling

indicates fluctuations in kokanee

numbers. The reservoir model now in. to Duncan and Corra Linn dams.

\section{SCHEDULE AND MILESTONES}

1. June 30, 1991: Biological model for the reservoir will be completed and runs will be made concurrently with the Systems Analysis Model. The biological model has been critically reviewed and will be improved by researchers at the University of Washington. predators. Fall drawdown is particularly damaging to cutthroat growth rates.

1. June 30, 1991: Biological model for the reservoir will be completed and runs will be made concurrently with the systems Analysis Model. The biological model has been critically reviewed and will be improved by

(1)

\section{Work on fish entrainment through the} Libby Dam penstocks and effects of operations on the river fishery will continue in Fy 1992 to increase utility of the reservoir model. 
PROJ ECT

NUMBER

83.467

(cont.)

compatible with the needs of the fish.

3. To perform an instream flow

study below Libby Dam.

III. NEW PROJECTS

None. 
WILDLIFE ACTION ITEMS AND TECHNICAL SUBJECTS 
8.1

LOSS STATEMENTS

(Fund as Needs are Identified.)

1003(b)(3) [Abstract] Bonneville shall fund studies to develop statements of wildlife and habitat losses at the projects listed in Table 3 of the Fish and Wi Idlife Program, including power-related storage and regulatory dams. These statements shall take into account all existing information pertinent to the project area and shall address both realized and potential positive and negative effects.

\section{ACTION I TEM ACTI VITY SUMMARY:}

\section{Objectives:}

To obtain an estimate of the net impacts on wildlife and habitat from development and operation of Col umbia River Basin Federal hydroelectric facilities. This information will be used in developing objectives to protect, mitigate, and enhance wi Idlife affected by hydro development and operation.

\section{Background and Progress to Date:}

The development of the hydroelectric system has caused both adverse and beneficial effects on wildlife and habitat. Action ltem 8.1 calls for the funding of studies to identify net impacts on wildlife and wildlife habitat from hydroelectric development and operation. Study information will be used to develop Action Item 8. 3: wildlife protection, mi tigation, and enhancement plans.

Loss assessments have been completed for 22 of the 29 FCRPS facilities. Two facilities (Roza, and Chandler) do not require loss assessments. The U.S. Army Corps of Engineers has funded loss assessments for the Lower snake facilities. The loss assessment for Chief Joseph Dam and Reservoir is currently ongoing lsee Project 88.44 under Action Item 8.3).

\section{PI ans:}

The Clearwater River otter Study (Project 90-51) will continue and be completed in FY 1992. 
1. COMPLETED PROJECTS

None

11. FY 1991 ONGOING PROJECTS

\begin{tabular}{ll} 
PROJECT & \multicolumn{1}{c}{ TITLE } \\
NUMBER & Clearwater River otter study \\
& - NPT \\
& Project officer: s. Levy \\
& Objectives: Provide baseline \\
& data on population status, \\
& habitat use patterns, seasonal \\
& distribution, and food habitats \\
& of otters al ong the clearwater \\
& River and its tributaries. \\
& This information will help \\
& identify site-specific limiting \\
& factors affecting otter pop. \\
& ulations in the clearwater \\
& River drainaqe and help direct \\
& mitigation efforts towards \\
& the selection of effective \\
mitigation techniques and & locations of mitigation ef. \\
& forts.
\end{tabular}

PROJECT STATUS

Date Initiated: September 1990

Results/Conclusions: Final report due July 1992 .
SCHEDULE AND MILESTONES

FY 1991: Continue monitoring of river otter per study.

FY 1992: Draft report due September 31, 1992. Final report due August $31,1992$.

III. NEW PROJECTS

None. 
8.2 LOSS STATEMENT CONSULTATIONS

(Begin Consultation)

1003 (b)(4)(A) [Abstract]Upon completion of the 1003(b)(3) studies, the appropriate fish and wildlife agencies, Tribes, BPA, and project operators for each project shall review the results and discuss the options available to provide wildlife protection, mitigation, and enhancement in accordance with the Northwest Power Act.

ACTION ITEM ACTIVITY SUMMARY:

Objectives:

To provide a review of Action Item 8.1, loss assessments, and to assist in the development of Action Item 8.3, wildlife protection, mitigation, and enhancement plans. No projects/contracts will be funded by BPA in implementing this Action Item.

Background and Progress to Date:

Consultations have been held on 19 of the 29 FCRPS facilities. Consultations are not anticipated for six facilities. Table 8 outlines the status of these consultations.

PI ans:

No loss statement consultations are expected in Fy 1992.

\section{Projects:}

None. 
TABLE 6

STATUS OF ACTION ITEM 8.2 WI LDLIFE CONSULTATIONS

AT FCRPS FACILITIES

Hydro Facility

Status

Montana

Hungry Horse Held

Li bby Held

Idaho

Pal i sades

Held

Anderson Ranch Held

Black Canyon Held

Boise Diversion Held

Dworshak

Held

Albeni Falls Held

Mi ni doka

Held

Washingt on

Grand Coulee Held
Chief Joseph Held
Lower Snake
(Ice Harbor, None Proposed
Lower Monumental,
Little Goose,
Lower Granite>
Chandler None Proposed
Roza None Proposed

Out come

Mitigation plan was funded.

Mitigation plan was funded.

Determined it was not effective to $f$ und development of a mitigation plan.

Mitigation plan was funded.

Combined loss assessment and mitigation plan funded.

Mitigation plan was funded.

Mitigation plan was funded.

Combined loss assessment and mitigation plan funded. FY 1991.

Mitigation planning being conducted by USACE.

Status Review findings indicated no need for mitigation planning.

Stat us Review findings indicated no need for mitigation planning. 


\section{Hydro Facility}

Oregon

Wi I I a met te

$\begin{array}{ll}\text { Cougar } & \text { Held } \\ \text { Lookout Point } & \text { Held } \\ \text { Dexter } & \text { Held } \\ \text { Hills Creek } & \text { Held } \\ \text { Green Peter } & \text { Held } \\ \text { Foster } & \text { Held } \\ \text { Detroit } & \text { Held } \\ \text { Big Cliff } & \text { Held }\end{array}$

Oregon/Washington

Bonneville

The Dalles

John Day

McNary

Held

Held

Held

Held
Mitigation plan was funded.
Mitigation plan funded in Fy 1991.

Mitigation plan funded in Fy 1991.

Mitigation plan funded in Fy 1991.

Mitigation plan funded in Fy 1991. 


\section{3 MITIGATION PLANS}

(Fund Development)

1003(b)(4) [Abstract] Bonneville shall fund the development of mitigation plans for each of the projects listed in Table 3 of the Fish and Wildife Program, including power-related storage and regulatory Dams .

\section{ACTION ITEM ACTIVITY SUMMARY:}

Objectives:

To identify target wildlife species for protection, mi tigation, and enhancement; to devel op protection, mitigation, and enhancement goals/objectives; and to coordinate mi tigation goals/objectives with interested and involved parties for Federal hydroelectric facilities.

Background and Progress to Date:

Action Item 8.3 pertains to the development of wildlife protection, mitigation, and enhancement plans. These plans are to take into account the wildlife impacts identified under Action Item 8.1, are to complement existing wildlife management plans and goals, and are to take into account the standards outlined in Measure 1003(b)(4)(c). Wildlife protection, mitigation, and enhancement goals/objectives developed in these plans are submitted to the Council for their approval and prioritization.

Table 9 outlines the status of mitigation plans at FCRPS facilities. Mitigation plans have been completed for 16 of the 29 FCRPS facilities. Mitigation plans are not anticipated for seven FCRPS facilities (Roza, Chandler, Boise Diversion, and Lower snake Facilities).

Plans:

Mitigation plans for Minidoka, Bonneville, The Dalles, John Day, and McNary Dams will continue and be completed in Fy 1991. Mitigation plan for Chief Joseph will be completed in FY 1992. 
TABLE 7

STATUS OF ACTI ON ITEM 8.3 WILDLIFE MITIGATION PLANS AT FCRPS FACILITIES

Hydro Facility

Mont ana

Hungry Horse

Libby

Idaho

Pal i sades

Anderson Ranch

Bl ack Canyon

Boise Diversion

Dworshak

Mi ni doka

Al beni Falls

Washington

Grand coulee

Chief Joseph

Ice Harbor

Lower Monumental

Little Goose

Lower Granite

Chandl er

Roza

oregon

Cougar
Lookout Point
Dexter
Hills Creek
Green Peter
Foster
Detroit
Big Cliff

Oregon/Washingt on

Bonneville

The Dalles

John Day

McNary
Compl et ed

Completed
Completed

Ongoing

None Proposed - Conducted by USACE

None Proposed - Conducted by USACE

None Proposed - Conducted by USACE

None Proposed - Conducted by USACE

None proposed

None proposed

All completed

To be completed in FY 1991.

To be completed in Fy 1991.

To be completed in Fy 1991.

To be completed in FY 1991. 
1. COMPLETED PROJECTS

PROJECT

NUMBER

$90-25$

$$
\begin{aligned}
& \text { Lower Col umbia Wildlife } \\
& \text { Mitigation PIan - USFWS }
\end{aligned}
$$

Proiect officer: DeHerrera

Obiectives:

1. Identify target wildlife species for protection,

mitigation, and enhancement.

2. Develop protection,

mitigation, and enhancement goals/objectives.

3. Coordinate project activities wi th involved and interested

parties (public involvement).

Minidoka Dam Wildlife

Mitigation PIan - I DFG

Proiect officer: R. Austin

Obiectives:

1. Develop and prioritize

protection, mitigation, and

enhancement goals for wildife

affected by hydroelectric

development and operation (e.g.,

Wi I dlife Mitigation PIan).

2. Recommend protection,

mitigation, and enhancement

actions.

3. Coordinate project acitivities

with interested/involved parties

( public involvement).
PROJECT STATUS

Expected Completion Date: May 1991

Results/Conclusions: Not available at

this time.

\section{Expected Completion Date: May 1991}

Results/Conclusions: A "draft" mit i. gation plan has been prepared by Idaho Department of Fish and Game, which coordinated project activities with an interagency work group. The work group developed the following prioritized mitigation goals: 1531 river otter habitat units (HU's) in riparian river grouse HU's in shrub-steppe habitat, habitat, 1,922 sage 1,746 mule deer HU's in shrub steppe habitat, and 175 yellow warbler HU's in deciduous scrub-shrub wetl and habitat. 
11. FY 1991 ONGOING PROJECTS

PROJ ECT

NUMBER

$88 \cdot 44$

Chief Joseph Wildlife

Mitigation PIan - WDW

Project officer: J. DeHerrera

Objectives:

1. Develop and prioritize

protection, mitigation, and

enhancement goals for wildife

affected by hydroelectric

development and operation

(e.g., Wildlife Mitigation PIan).

2. Recommend protection,

mitigation, and enhancement

actions.

3. Coordinate project acitivities

with interested/involved parties

( public involvement).
PROJECT STATUS

Date Inititiated: February 1991

Results/Conclusions: None at this time. August 1991: Public review.

N్

January 15, 1992: Final mitigation plan.

\section{II. NEW PROJECTS}

None 
$8.4 \quad$ LIBBY DAM MITIGATION

(Initiate Advance Design for White-Tailed Deer, Mule Deer, Columbia Sharp-Tailed Grouse, and Waterfowl Projects; Continue Implementation and Monitoring of Bighorn Sheep Project: 1987)

$8,5 \quad$ LI BBY DAM MI TI GATI ON

(Continue Advance Design for Deer, Waterfowl, Grouse Projects; Begin I mplementation and Monitoring for Mule Deer Project; Continue I mplementation and Monitoring of Bighorn Sheep Project: 1988)

8.6 LIBBY DAM MI TI GATI ON

(Begi n Implementation and Monitoring for White-Tailed Deer, Grouse, and Waterfowl Projects; Continue I mplementation and Monitoring of Mule Deer and Bighorn Sheep Projects: 1989)

8. 7 LI BBY DAM MI TI GATION

(Continue Implementation and Monitoring for White-Tailed Deer, Mule Deer, Bighorn Sheep, Grouse, and Waterfowl Projects: 1990. 1991)

1003(b)(7) [Abstract] Bonneville shall implement council approved mitigation priorities and plans at Federal projects through the I mplementation PIanning Process. Council-approved mitigation plans and priorities for Libby Dam are listed in Table 4 of the 1987 Fish and Wildlife Program.

Table 4 calls for BPA to undertake projects to enhance winter range in Northwest Montana to support a target carrying capacity of an additional 1,340 white-tailed deer, 485 mule deer, and 66 bighorn sheep. Table 4 also calls for the protection of 2,462 acres of prairie habitat for Columbia sharp-tailed grouse, and 3,418 acres of wetland habitat in the Flathead Valley.

\section{ACTI ON ITEM ACTIVITY SUMMARY:}

\section{Objectives:}

To undertake advance design and then begin implementation of the wildlife mitigation projects for Libby Dam.

Background and Progress to Date:

Action ltems 8.4 through 8.7 pertain to the advance design and i mplementation of wi Idife mi tigation projects for Libby Dam.

In Fy 1987, BPA began advance design for the wildlife habitat improvement and protection projects. In FY 1988, BPA continued advance design and began big game habitat improvement projects. Big Game habitat improvement projects were continued in Fy 1989 and Fy 1990. Sharp-tailed grouse work was initiated in FY 1989 and continued in Fy 1990 . 
PI ans:

BPA plans to continue and complete projects for bighorn sheep, mule deer, and sharp-tailed grouse in Fy 1991. Future wildlife projects for Libby Dam will be funded through the Montana Wildlife Mitigation Trust Agreement. 


\section{PROJ ECT}

NUMBER

$87 \cdot 55$

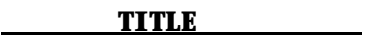

Northwest Montana WiIdlife Habitat Enhancement - MDFWP

Proiect officer: R. Walker

Objectives: This project under. takes advance design of the habitat enhancement actions for Libby and Hungry Horse Dams. 1. Develop a habitat enhancement plan for elk/mule deer on Flathead National Forest Iands.

2. Develop a habitat enhancement plan for mule deer/bighorn sheep on Kootenai National Forest Iands.

\section{FY 1991 ONGOING PROJECTS}

\section{PROJECT}

NUMBER

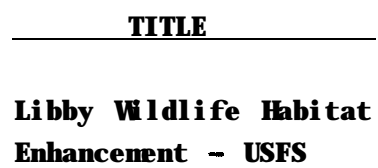

88.43

Proiect officer: R. Walker

Obiectives: Initiate habitat

improvement activities on Kootenai National Forest I ands for mule deer and bighorn sheep. Treat approximately 1000 acres of key winter range by slashing and prescribed burning.

PROJECT STATUS

Date Completed: January 1991

Results/Conclusions: Not available at this time.

PROJECT STATUS

Date Initiated: September 1988.

Results/Conclusions: Not available at this time.

\section{SCHEDULE AND MILESTONES}

1. Spring 1991: Continue habitat treatments.

2. December 1991: Project Completion. 
PROJECT

NUMBER

$90-49$

Libby/Hungry Horse

Wildlife Project - MDFWP

Project officer: $R$. Walker

Objectives:

1. Determine critical habitats

necessary for the protection,

enhancement, and maintenance

of grouse on the Tobacco PIains.

2. Develop a mitigation strategy

for grouse.

3. Refine the habitat protection programs for Libby and Hungry Horse.

4. Coordinate project activities with interested/involved parties.

$\mathbf{N}$

\section{PROIECT STATUS}

Date Initiated: May 1990

Results/Conclusions: Not available at this time.
SCHEDULE AND MILESTONES

1. March 1991: Status report on Libby/Hungry Horse Habitat Protection Program.

2. April 1992: Draft report on grouse mitigation program.

3. June 1992: Final report on grouse mitigation program and project completion 
8.8 HUNGRY HORSE DAM MITIGATION

(InitiateAdvance Design/Begin to I mplement Elk/Mule Deer Project; Begin Advanced Design, Interagency Coordination, Site Prioritization, and Appraisals for Black Bear/Grizzly Bear, Waterfowl, Terrestrial Furbearer Projects: 1987.)

8.9 HUNGRY HORSE DAM MI TI GATI ON

(Continue Advance Design Waterfowl, Terrestrial Furbearer, Black Bear/Grizzly Bear Projects; Continue I mplementation/Monitoring of Elk/Mule Deer Project: 1988.)

8.10 HUNGRY HORSE DAM MI TI GATI ON

(Begin/Continue I mplementation of Waterfowl, Elk/Mule Deer, Black Bear/Grizzly Bear Projects: 1989-1991.)

1003(b)(7) [Abstract] Bonneville shall implement council approved mitigation priorities and plans at Federal projects through the Implementation Planning Process. Council-approved mi tigation plans and priorities for Hungry Horse Dam are listed in Table 4 of the 1987 Fish and Wildlife Program.

Table 4 calls for BPA to undertake projects to enhance winter range in Northwest Montana to support a target carrying capacity of additional 133 elk. Table 4 also calls for the protection of 8,590 acres of riparian habitat for grizzly bears and 1,146 acres of wetland habitat, al ong with determining the feasibility of protecting 11,050 acres of old-growth timber for terrestrial furbearers.

\section{ACTION ITEM ACTIVITY SUMMARY:}

Objectives:

To undertake advance design and then begin implementation of the wildlife mitigation projects at Hungry Horse Dam.

Background and Progress to Date:

Action Items 8.8 through 8,10 pertain to the advance design and i mplementation of wildlife mitigation for Hungry Horse Dam.

In Fy 1987, BPA initiated advance design for the wildlife habitat i mprovement and protection projects. In FY 1988, BPA continued advance design and began habitat improvement and protection projects. InFy 1989 and Fy 1990, habitat i mprovement and protection projects were continued.

Plans:

BPA plans to continue and complete activities for the elk/mule deer habitat enhancement projects and the easement/acquisitions (habitat protectionl projects in Fy 19g1. Future wildlife projects for Hungry Horse Dam will be funded through the Montana Wildlife Mitigation Trust Agreement. 
1. COMPLETED PROJECTS

None.

11. FY 1991 ONGOING PROJECTS

PROJ ECT

NUMBER

Hungry Horse Wildlife

Habit at Enhancement - USFS

Proiect officer: $R$. Walker

Objectives: Begin habitat

i mprovement activities on

Flathead National Forest I ands

for elk and mule deer. Treat

approximately 500 acres of key

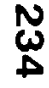

wi nter range by slashing and

prescribed burning.

$89-23$

\section{Montana Wildlife Habitat \\ Protection - MDFWP}

Proiect officer: R. Walker

\section{Obiectives:}

1. Obtain information to

evaluate specific habitats

for protection.

2. Provide coordination for

project actions.

3. Protect specific habitats.

\section{PROJECT STATUS}

Date Initiated: September 1988

Results/Conclusions:

at this time.

Date Initiated: September 1989

Results/Conclusions: None at this ti me.
1. May - June 1990: Evaluate feasibility of modifying project to protect specific habitats.

2. September 1990: Report summarizing project activities.

3. September 1990: Project modification

to provide for protection of specific

habitats through Grant.

4. October 1991: Draft completion report due.

5. December 1991: Final completion report due.

III. NEW PROJECTS

None. 
8.11 PUBLIC I NVOLVEMENT ON MITIGATION PLANS

(Fund Public Involvement Concerning Mitigation PIans)

$1003(b)(4)$ (B) [Abstract]Bonneville shall fund the entity or entities preparing mitigation plans to conduct appropriate public involvement activities to ensure that interested and affected parties are informed concerning the mitigation plans and have been afforded the opportunity to comment on them.

\section{ACTION I TEM ACTIVITY SUMMARY:}

\section{Objectives:}

To conduct appropriate public involvement for the mitigation plans being developed pursuant to Measure $1003(b)(4)$. No

projects/contracts will be funded by BPA under this Action Item.

Public involvement will be funded as part of the mitigation planning effort under Action Items 8, 1 and 8,3 .

\section{Background and Progress to Date:}

Public involvement on mi tigation plans for Grand Coulee Dam in Washington; Palisades, Black Canyon, Anderson Ranch, Albeni Falls, and Dworshak and Mi nidoka Dams in Idaho; Bonneville, the Dalles, John Day and McNary Dams on the Lower Columbia; and for the Willamette facilities in oregon have been completed by the entities that prepared these plans.

\section{Plans:}

Public involvement for mitigation plan for Chief Joseph will be completed in FY 1992.

Projects:

None. 
8.12 FUND I MPLEMENTATI ON OF MITIGATION PRIORITIES

(Fund Mitigation Priorities approved by the council)

$1003(b)(7)$

Bonneville shall implement Council approved mitigation priorities and plans at Federal projects through the i mplementation planning process. Projects to be implemented shall take into consideration the standards listed under Measure $1003(b)(7)$. [ Abstract]

\section{ACTI ON I TEM ACTI VI TY SUMMARY}

Objectives:

To identify, develop, and implement projects for priority wildlife mitigation objectives for Federal hydroelectric facilities.

Background and Progress to Date:

Wi I dife mitigation has been implemented in the states of oregon, Washington, or Idaho. Efforts to date have been directed towards Phase I implementation and acquisition.

The Council adopted wildlife mitigation priorities for Grand Coulee Dam in Washington; for Palisades, Bl ack Canyon, Mi nidoka, Dworshak, Anderson Ranch, and Al beni Falls Dams in Idaho; and for the Willamette facilities in Oregon. BPA initiated funding for six projects in Fy 1991 utilizing Fy 1991 placeholder funds.

PI ans:

BPA will continue to i mplement activities begun under Fy 1991 projects and plans to initiate additional wildlife mitigation projects for Federal hydroelectric facilities in Oregon, Washington, and Idaho in Fy 1992 per placeholder project, Project 91.16. 
I. COMPLETED PROJECTS

None.

II. FY 1991 ONGOING PROJECTS

PROJ ECT

NUMBER

$90-91$

Dworshak old Growth - I DFG

Proiect officer: J, DeHerrera

Obiectives: Protect, through

acquisition, 108 acres of "old

growth" timber and adjacent

mature forest. Develop manage. ment $p l a n$ and Terms of Title

for I daho

$90-92$

Conforth Ranch Advance Design St udy - USFWS

Proiect of ficer: R. Walker

Obiectives: Conduct advance design study to facilitate decision on implementation of acquisition. With Council consent, implement decision on acquisition and conduct manage. ment planning and NEPA process.

$91 \cdot 61$

Pygmy Rabbit/Tracy Rock Sharp

Tail Grouse - WDW

Proiect officer: $R$. Walker

PROJECT STATUS

Date Initiated: September 1990

FY 1991: Fund acquisition.

Results/Conclusions: None at this ti me.

FY 1992: Develop and i mplement management $p l a n$ and operations and maintenance program.

Date Initiated: September 1990

Results/Conclusions: None at this time.
FY 1991: Complete feasibility study, conduct Habitat Evaluation Procedure (HEP), and fund acquisition, dependent on analysis and appraisal results and NPPC recommendation. Develop management plan.

FY 1992: I mplement management $p l a n$ and operations and maintenance program.
Expected Start Date: April 1991 Results/Conclusions: None at this ti me.
FY 1991: Complete Phase I.

FY 1992: Initiate Phase II. 
PROJ ECT

NUMBER

91.63

cont.

1.60

\section{TITLE}

Obiectives:

Phase I: Develop programmatic

management $\mathrm{plan}$, NEPA, memo.

$r$ andum of agreement wi th WDW,

Habitat Evaluation Procedure

(HEP) and easement terms and

conditions for manament area.

I nventory and prioritize

acquisition/protection areas.

Phase II: I mplement easement I

fee acquisition as per plan.

Initiate necessary operations

and maintenance programs.

Pend Oreille Wetlands - UCUT

Project officer: J. DeHerrera

Obiectives: Protect through fee acquisition, 440 acres of wetlands and riparian habitat. Devel op management $p I a n / N E P A$ and MOA with Kalispel Tribe. I mplement management plan for enhancement and protection activities.

BI ue Creek Winter Range Spokane Tribe (UCUT)

Proiect of icer:

R. Walker

Obiectives: Protect through easement acquisition 4,400 acres of Tribal lands. Fund manage. ment plan to address protection/ enhancement of target species: white-tail deer, sharptail grouse, ruffed grouse.

Expected Start Date: April 1991

Results/Conclusions: Not available HEP analysis. Fund management plan,

with public involvement.

FY 1992: I mplement management $p l a n$ and 0\&M program.

Expected Start Date: April 1991

Results/Conclusions: None at this ti me.
FY 1991: Complete programmatic management plan, NEPA, MOA, and negotiate easement terms and conditions.

FY 1992: Negotiate conservation easement or agreement with spokane Tribe on all or portion of 4,400 acres. 
PR이 EC

NUMBER

$91 \cdot 63$ South Fork Snake River I DFG and TNC

\section{Project Officer: R. Walker}

Obiectives:

Phase I: Complete programmatic management $p I$ an, NEPA, MOA and HEP; develop easement terms and conditions. Inventory and prioritize acquisition/pro. tection areas.

Phase II: I mplement easement fee acquisition as per plan.

Initiate necessary operations and maintenance programs.

\section{II. NEW PROJECTS}

PROJ ECT

NUMBER

$91 \cdot 1$

\section{TI TLE}

Wildlife Mitigation - FY 1992

(Oregon, Washington, I daho)

Proiect of ficer: R. Walker

Qbiectives: Begin develop.

ment and implementation of

wildlife mitigation projects

for Federal facilities in

Oregon, Washington, and Idaho.

Multiple mitigation actions

(projects) will be developed

and $i \mathrm{mpl}$ emented.

\section{PROJECT STATUS}

\section{Expected Start Date: April 1991}

Results/Conclusions: None at this ti me.

PROJECT STATUS

New Project

\section{SCHEDULE AND MILESTONES}

FY 1991: Complete Phase I.

FY 1992: Initiate Phase II.
SCHEDULE AND MILESTONES

1. Initiation of new projects contingent upon funding availability and implementation status of FY 1991 projects.

2. Initiation is also dependent upon scopes of work being developed and coordinated for priority mi tigation objectives. 
8.13 DEVELOP MONI TORI NG AND EVALUATI ON PROGRAM

( In Consultation with Involved Parties, Develop a

Monitoring and Evaluation Program>

1003(c) Bonneville shall develop in consultation with the council, the fish and wildlife agncies and tribes, utilities, and other interested parties a comprehensive program to monitor and evaluate the effectiveness of the wildlife program.

\section{ACTION ITEM ACTIVITY SUMMARY:}

Objectives:

To develop and implement a program to monitor and evaluate wildi ife projects funded by BPA.

\section{Background and Progress to Date:}

Wi I dife mitigation to date has been limited to efforts for Libby and Hungry Horse Dams in the State of Montana. Monitoring and evaluation of these activities are being undertaken through the Montana Wild if e Mitigation Trust Agreement. Mitigation has not yet been initiated for facilities in Oregon, Idaho, and Washington. Monitoring and evaluation will be undertaken as part of the mitigation efforts in these states.

Plans:

In Fy 1991, BPA will initiate development with the council, the fish and wildlife agencies and tribes, utilities, and other interested parties a wildlife monitoring and evaluation program. Actions to be undertaken and/or funded will be determi ned through this planning effort. In FY 1992, BPA will contract with outside source for program development after parameters are established by consultations. 
COMPLETED PROJECTS

None.

11. FY 1991 ONGOING PROJECTS

None.

111. NEW PROJECTS

PROJ ECT

NUMBER

$92 \cdot x \times x$

Monitoring and Evaluation Program

Proiect officer: R. Walker

Objectives: To develop, per the Council's Wildlife Rule,

a monitoring and evaluation

program that establishes

parameters, methodology and

guidelines for monitoring and

evaluating ongoing wildlife

mitigation, protection, and

enhancement projects, basin-

wi de.

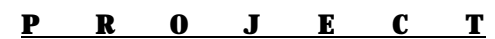

New Project

\section{SCHEDULE AND MILESTONES}

Fy 1991: Initiate consultations to formulate scope.

FY 1992: Complete development of monitoring and evaluation program. Initiate implementation of the program. 


\section{FUND. OF HUNGRY HORSE/LIBBY MITIGATION}

I NNOVATI VE FUNDING OF HUNGRY HORSE/ LI BBY MI TI GATION

(Fund the Montana Wildlife Trust)

$1003(b)(7)$

[Abstract] Bonneville shall implement Council approved mi tigation priorities and plans at Federal Projects. Council approved mi tigation plans and priorities for Libby and Hungry Horse Dams are listed in Table 4 of the 1987 Fish and Wildlife Program.

\section{ACTION ITEM ACTIVITY SUMMARY:}

\section{Objectives:}

I mplement the Wildlife Mitigation Agreement (Montana Trust Fund) negotiated between BPA and the state of Montana for funding wildlife mitigation for Libby and Hungry Horse dams.

Background and Progress to Date:

BPA and the State of Montana signed a mi tigation agreement in December 1988. The agreement establishes a $\$ 12,5$ million Trust Fund to finance wildlife mi tigation for Libby and Hungry Horse Dams. BPA made its first payment of $\$ 2$ million to the Trust Account in December 1989 and a subsequent payment of $\$ 2$ million in December 1990.,

PIans:

BPA plans to make its scheduled payment to the Trust account in December 1991. 
1. COMPLETED PROJECTS

None.

11. FY 1991 ONGOING PROJECTS

PROJ ECT

NUMBER

TITLE

$89 \cdot 52$

Montana Wildlife Trust

Proiect of ficer: R. Walker

\section{Objectives}

Establishes a $\$ 12,5$

million Trust Account.

2. Sixty year agreement.

3. Addresses impacts to wild.

I ife from the development of

Libby and Hungry Horse Dams.

4. Montana, through the use

of Trust Account, responsible

for Wildlife Mitigation.

111. NEW PROJECTS

None.
PROIECT STATUS

Date Initiated: December 1988

Results/Conclusions: I nitial payment of $\$ 2$ million was made

to the Trust Account

in December 1989. Subsequent payment

of $\$ 2$ milion made in December 1990 .
SCHEDULE AND MILESTONES

1. December 1991: Make scheduled payment to the Trust Account.

2. Subsequent payments to be made on an anual basis. 
FUTURE HYDROELECTRIC DEVELOPMENT ACTION ITEMS AND TECHNICAL SUBJECTS 
9.1 APPLICATION OF PROGRAM SECTIONS 1204(a), (b). (c). AND (e) TO NEW PROJECTS

$1103(a \cdot c, e)$ [Abstract] These measures direct BPA and the hydroelectric project operators and regulators not to license, exempt from license, relicense, propose, recommend, agree to acquire power from, grant billing credits for, or otherwise support any hydroelectric development in the Columbia River Basin without providing for numerous development conditions related to protection of fish and wildlife resources.

ACTI ON ITEM ACTIVITY SUMMARY:

\section{Objectives:}

To apply Program Section $1103(a-c$, e) to all new hydro projects.

Background and Progress to Date:

BPA is applying these Program sections to the BPA Hydro Options Program.

Plans:

BPA will continue to apply these program sections to the BPA Hydro Options Program and any future hydro development.

\section{Projects:}

No BPA. funded projects. 
9.3 ASSESSMENT OF CUMULATI VE EFFECTS

(Complete Study; Develop Methods: June 1987)

$1103(b)(2)$ Develop methods for assessing the cumulative effects of hydroelectric development upon fish and wildlife in the columbia River Basin.

ACTION ITEM ACTIVITY SUMMARY:

Objectives:

To review all pertinent literature on potential cumulative hydroelectric effects, for specific key fish and wildlife species; to analyze existing techniques for assessment of identified cumulative effects; to develop an array of recommended pertinent assessment techniques for a cumulative effects method; and to develop a hypothetical example of a cumulative assessment using the method.

Background and Progress to Date:

Development of a cumulative effects method supported the council's desire to have all applications or proposals for hydroelectric development reviewed in a consolidated manner. Project 84.41 (completed in 1987) developed a methodology to assess potential cumulative effects.

Plans:

BPA has no plans for further funding.

\section{Projects:}

No BPA-funded projects. 
9.4 TURBINE I NTAKE SCREENS

(Develop New Designs, Complete Tests, Report to Council: January 1989)

$1103(d)$

Bonneville shall fund studies to determine the effectiveness of new designs for turbine intake screens and their suitability for application at small hydroelectric projects.

ACTION I TEM ACTI VI TY SUMMARY:

Objectives:

To develop a new standard fish screen that is biologically efficient and cost-effective for hydro developers.

Background and Progress to Date:

Installation and maintenance of currently available screening systems are expensive and must be tailored to the site. Most present screen systems have not been tested sufficiently to be characterized as proven. Existing designs and new designs must be evaluated to determine which designs are biologically and economically efficient. The suitability of screen designs for application at small hydroelectric facilities must also be determined. The intent is to provide acceptable fish screen designs with general applicability for regional hydropower developers.

PI ans:

Presently deferred, since BPA's adoption of Protected Areas in its Long-Term Intertie Access Policy provides protection for fish investments through denying access to the Pacific Northwest.Pacific Southwest Intertie to any new hydroelectric projects located in designated Protected Areas of the Columbia River Basin.

\section{Projects}

No BPA. funded projects. 
WORK AND EXPENDITURE PLAN

ACTION ITEMS 
10.1- EXPENDITURE AND OBLIGATION PLANS

10.3 (Submit to Council by September 15 of Each Year. Update and Submit Information Quarterly. Submit Review of Previous Year. Report

Expenditures by Measure. )

1203(a,c,d) [Abstract] These measures describe Program implementation by Federal project operators and regulators and BPA, consultation and coordination, and BPA funding of the Program.

\section{ACTI ON ITEM ACTIVITY SUMMARY:}

Objectives:

The Annual I mplementation Work PIan (AIWP) describes BPA plans for i mplementation of the Council's Program and, in particular, the Action Plan. The Al WP is intended to contain:

1. A report on progress to date on each Action Item.

2. A description of the activities to be undertaken under each Action Item, including;

a. the objective of each activity, and

b. the schedule for each activity, including key decision points and major milestones.

\section{Background and Progress to Date:}

Annually since FY 1986, BPA has completed a Program Work PI an and submitted this plan to the council.

In 1987, BPA began developing a Program Implementation PIanning Process (IPP) that would provide an opportunity for the agencies, Tribes, and other interested parties to become more involved in planning the implementation of the Program. Development of this process was completed in 1988, and the IPP (see section III) was endorsed by the BPA Administrator and the Chairman of the CBFWA on october 19, 1988. The IPP's Policy Review Group (PRG) was formed in late 1988. In January 1989, the PRG began providing BPA with policy and funding recommendations related to Program implementation. The AI WP is based on the outline developed by the PRG during step 1 of the annual IPP annual cycle.

PI ans:

The AIWP will continue to be developed through the IPP. 
PROGRAM-RELATED， NON-MEASURE PROJECTS 


\section{PROGRAM-RELATED PROJECTS}

\section{PROGRAM-RELATED PROJECTS}

MEASURE LANGUAGE:

Not applicable. These are non-measure projects.

TECHNI CAL SUBJECT ACTIVITY SUMMARY:

See individual projects in the following table. 
I. COMPLETED PROJECTS

PROJ ECT

NUMBER

$87 \cdot 130$

An Assessment of the Freeze

Brand Recovery Data for Yearling

Chinook Salmon at McNary Dam NMF S

Proiect officer: D. Johnson

Obiectives: Determine whether

PIT-tagged and freeze-branded

yearling chinook and steelhead

are recovered at different rates

and identify the sources of

sampling error.

$\stackrel{N}{8}$

$82 \cdot 16$

Yaki ma River Spring Chinook

Enhancement Study - YIN

Proiect officer: T, Vogel

Obiectives: Establish

methods to rebuild spring

chinook salmon runs in the

Yakima River while maintaining

the genetic components of the

naturally reproducing stocks.

\section{FY 1991 ONGOING PROJECTS}

\section{PROJ ECT}

NUMBER

$82 \cdot 13$ TI TLE

Coded Wire Tag/Sampling

Program Recovery - PSMFC

Proiect officer: P. Poe

Obiectives: Support WDF, WDW,

\section{PROJECT STATUS}

Date Completed: 1990

Results/Conclusions: Information pending for first draft. Final report is in print.

Expected Completion Date: April 1991

Results/Conclusions: I nformation has been collected on survival and emergence from redds, survival from fry to smolt, and downstream movement of

fry. Project annual reports are available; final report will be avail. able in April 1991.

\section{PROJECT STATUS}

Date initiated: 1982

Results/Conclusions: Commercial and sport fishery recoveries of coded-wire tagged salmon and steelhead were de. coded, compiled, and reported.
SCHEDULE AND MILESTONES

Continuing: BPA will continue to fund codedwi re tag recoveries. 
PROJ ECT

NUMBER
82.13 and ODFW fishery recoveries
(cont.) of coded-wire tagged salmon and steelhead.
86.13
Augmented Fish Health Monitoring in Washington - WDW

$86 \cdot 54$

Augmented Fish Health

Monitoring in Washington - WDF

87.117 Augmented Fish Health

Monitoring in Idaho - IDFG

$87 \cdot 118$

م
Augmented Fish Health

Monitoring in Oregon - ODFW

Augmented Fish Health

Monitoring - USFWS

Project of ficer: R. Morinaka

Objectives: collect data in a systematic, standardized manner and provide a system of rapid storage and retrieval of fish health/production information in the anadromous fish hatcher. ies of the Columbia River Basin. Begin to develop a documentation and data retrieval system that can be used by persons who are not fish diagnosticians.
Date initiated/completed:

87-13: Completion expected August 1991

87.54: Completion expected July 1991

87-117: Initiated June 1987

87.118: Initiated June 1987

87-119: Initiated July 1987

Results/Conclusions: Projects have assured consistent fish health data monitoring and reporting in the columbia Basin anadromous fish hatcheries.

Project summaries have been written to verify what parameters should be either dropped or continued in a monitoring program.
1. Continuing: Fund a comprehensive fish health management system through standardized monitoring.

2. Continuing: Ensure compatibility of the data generated by these projects with that of the Artificial and Natural Production Data Bases (Program Measure 204). 
PROJ ECT

NUMBER

$89-20$

\section{Airlift Fabrication}

Project of ficer: W. Masl en

Obiectives: Provide funding for fabrication of airlift

fish sampling devices and

miscellaneous supporting hard. ware for lce Harbor, John Day, and The Dalles Dams, as speci.

fied in the Fish Spill

Memorandum of Agreement.

This equipment supports

monitoring programs specified

under projects 84.14 and

$87 \cdot 127$.

N

90.80
Col umbia River Basin PIT-

Tag Information system (PTAGIS)

- PSMFC

Project officer: P. Poe

\section{Obiectives:}

1. To develop, operate,

maintain, and enhance a longterm Columbi a River Basin-wide database of information on

PIT-tagged fish to ensure that all PIT-tag information is

available in a timely and useful manner to all state, Federal, Tribal and other interested entities.

\section{- PROJECT STATUS}

Date Initiated: 1989

Desult teconclasionsir $l$ i f $t$

sampling device was fabricated for use

at The Dalles Dam.

\section{SCHEDULE AND MILESTONES}

Additional airlift fish sampling devices may be fabricated, as agreed by the parties.

\section{Date Initiated: May 1990}

Results/Conclusions: PTAGIS of ice
1. 1992: Operate, maintain, and enhance Columbia River PIT-tag systems and database.

established at the Pacific states Marine 2. Continuing: BPA will continue to fund Fisheries Commission (PSMFC) in Portland PTAGIS.

in 1990. Completed transfer of data and

maintenance of PIT tage systems from

NMFs, Seattle to PTAGIS, Portland, 1991. 
PROJ ECT

NUMBER

90.80

cont.

2. To perform all other

activities related to Col umbia

River PIT-tag systems including:

maintenance and documentation

of fish tagging and interrogation

systems: operation and maintenance

of equipment at the remote sites.

Provision of technical support for

software and hardware; provision

of training to users; and pur.

chase of PIT-tags and associated

equipment.

\section{NEW PROJECTS}

O PROJECT

NUMBER

TITLE

PROJECT STATUS

New Project

Proiect of ficer: W. Masl en

Objectives: As provided under

the terms of the Fish Spill MOA.

1. Determine fish guiding

efficiency of prototype bypass

screens.

2. Determine fish guiding

efficiency of installed bypass screens.

3. Evaluate various means to

i mprove fish guiding efficiency

of substandard bypass facilities.
SCHEDULE AND MILESTONES

\section{SCHEDULE AND MILESTONES}

FY 1992 and beyond: Provide funding as necessary to conduct prototype and post-installation testing of bypas screens (and sl ui ceway where appropriate), as provided in the Fish spill Memorandum of Agreement.

FY 1992 - 1993: Prototype testing of standardlength submersible traveling screens at Lower Monumental Dam, as per terms of the fish spill MOA.

FY 1993 - 1994: Prototype testing of standard length submersible traveling screens at I ce Harbor Dam, as per terms of Fish Spill MOA. 
VIII. NON-ACTION ITEM PROJECTS 
COMPLETED PROJECTS

None.

11. FY 1991 ONGOING PROJECTS

PROJECT

NUMBER

$91 \cdot 19$

Hungry Horse Fisheries
Mitigation - MDFWP

Project of icer: $F$ WH

Objectives: Replace hydro-

related losses of resident fish

in three major areas of the

system: Hungry Horse Reser.

voir, downstream river habitats

in the Flathead system, and

Flathead Lake. The project

should accomplish reasonable

mitigation for the impacts

of Hungry Horse Dam on res.

ident fish in the Flathead

drainage.

1II. NEW PROJECTS

None.
PROJECT STATUS

Expected Start Date: FY 1991

Results/Conclusions: None at this time.
SCHEDULE AND MILESTONES

FY 1991: Start project once council has amended. mitigation actions into the Program. 
IX. APPENDICES 
APPENDIX A

NON-PROGRAM, INTERNAL SUPPORT PROJECTS

This section of the AI WP Iists and describes BPA Division of Fish and Wildlife internal support projects. These projects do not implement measures in the Program and were not subject to PRG review as part of the IPP. The projects are included in the AIWP to help the PRG and the public to better understand what BPA is doing. 


\section{COMPLETED PROJECTS}

None.

11. FY 1991 ONGOING PROJECTS

PROJ ECT

NUMBER

86.118

\section{TITLE \\ Fish and Wildlife Task Order Agreement - BPNL}

Proiect officer: R. Austin

Obiectives: To supplement the limited staff and time resources of BPA's Division of Fish and Wildlife with the services of a professional contractor (BPNL), who can provide technical assistance on a wide variety of tasks.

$87 \cdot 413$ Fish and Wildlife Task Order Agreement, Fisheries Technical Assistance - UW

Proiect officer: V. Jagendorf

obiectives: To assist the limited staff and time re. sources of BPA's Division of Fish and Wildlife through the

\section{PROJECT STATUS}

Date initiated: J une 1986

Resul ts/Concusions: Nine task orders have been completed under this master task order agreement: (1) spring Chinook Outplanting, (2) Production/Cost Records, (3) Yaki ma Hatchery Master PIan, (4) Yaki ma Flow Enhancement, (5) Yakima Hatchery Master PIan II, (6) Smolt Sur. vival Workshop, (7) Predator/Prey Work. shop, (8) Hatchery Effectiveness TWG Workshop, (9) Anadromous Fish Release Workshop, (10) Evaluation of potential application of Burnham et al. (1987) statistical methods for estimating smolt survival in the Columbia River. If the task order implements a Program project, the task order is listed in the Al WP under the appropriate Action Item.

Date Initiated: September 1987

Results/Conclusions: Numerous task orders have been completed under this master task order agreement, including 1) review of Project 84.46, Development of a Vaccine for Bacterial Kidney Disease in Salmon; 2) review of BPA's anadromous fish passage assessment methods: 3) review of relevant
SCHEDULE AND MILESTONES

Fy 1992: Continue funding master task order agreement. Initiate individual technical assistance tasks orders as required by BPA staff.

Fy 1992: Continue funding master task order agreement. Initiate individual technical assistance task orders as required by BPA staff. 
PROJ ECT

NUMBER

87-413 services of a uniquely

cont.

qualified professional staff

able to provide technical

assistance on diverse fish

and wildlife issues.

$88-125$

Anadromous Fish PIanning and I mplementation Decision Support System - RFF

Proiect officer: M. Schneider

Objectives:

1. Complete cost.effective.

ness (C.E) analysis of

alternatives in selected

Subbasin PIans, utilizing

assistance from all possible

regional entities.

2. Compare existing and pro.

posed fish passage alternatives

with propagation alternatives

of Subbasin plans.

3. Provide technical partici. pation on Council's Analytical Methods Work Group (AMWG) to

integrate System PIanning Model (SPM) and Stochastic Life-Cycle Model (SLCM).

4. Long Term: Complete model components needed for C.E

analysis of mitigation issues, including training and assist. ance needed for use of models

by analysts in the region.
PROIECT STATUS

statistics and reports on population dynamics of Hanford Reach fall chinook salmon; and 4) conduct of a smolt survival workshop. If the task order i mplements a Program project, the project is listed in the AIWP under the ap. propriate Action Item.

Date Initiated: FY 1991

Results/Conclusions: A Stochastic Life-Cycle Model (SLCM) was developed to analyze effects of proposed actions. SLCM was applied to Wenatchee, Entiat, Methow, and Okanogan subbasins. C.E analysis was expanded to include other selected subbasins. SLCM was also applied to the BPA Accord-ESA actions.

FY 1992: Complete C.E analysis of selected Subbasin PIans. Prepare C.E comparison of all passage and production alternatives consistent with BPA passage alternatives. Assist in application of C.E analysis to Council's Program amendment process.

Fy 1993: In coordination with the Monitoring and Eval uation Work Group and UW's Center for Quantitative science, complete mitigation decision support system models and user guides, and provide user support. Review methods used to evaluate fish production potential and cost of plan options. 
PROJECT

NUMBER TI TLE

89.47 Technical Assistance

- Consultant

Proiect officer: D. Johnson

Obiectives:

1. Provide recommendations on fish passage related research and monitoring;

2. Assist in development of research designs.

89.62 I mplementation PIanning Process (IPP) Coordination = PSMFC

Proiect officer: J. Gislason

Obiectives:

1. Facilitate communication among BPA, CBFWA, Policy Review Group (PRG), Scientific Review Group (SRG), and IPP Scoping Groups (SG's).

2. Ensure the timely delivery of all PRG, SRG, and SG work products required by the IPP.

3. Administer financial support (time and travel expense reimbursement) of non-Federal SRG scientists.
PROJ ECT STATUS

Date Initiated: $\quad 1989$

Results/Conslusions: Various technical recommendations on Water Budget Effectiveness and Reservoir Mortality have been made to BPA.

\section{Date Initiated: May 1989}

Results/Conclusions: BPA has funded an IPP Coordinator position with the

CBFWA through a contract with the PSMFC. Through this contract, BPA also reim-

burses most of the SRG members or

their employers for the time that the

members spend on SRG activities.

BPA also funds seven SG Chairs, who are

are designated by the CBFWA, through the the contract with PSMFC.

\section{SCHEDULE AND MILESTONES}

Continuing: Schedule and mi lestones vary with timing of issues and receipt of proposals.

FY 1992: BPA plans to continue funding the IPP Coordination contract. 
PROJ ECT NUMBER

$89 \cdot 72 \cdot 1$

$89 \cdot 108$
Results/Conclusions: BPA provides financial support for one $S R G$ member through this contract.

support (time and travel expense reimbursement) for SRG scientist empl oyed by DOE.

Col umbia River Salmon

Passage Model - UW

Proiect officer: V. Jagendorf

\section{Obiectives:}

1. Replace FISHPASS model.

2. Develop graphical input

and output features.

3. Develop Monte Carlo and multi-

year analytical capabilities

4. Integrate database system.

5. Develop and calibrate

mechanistic submodels.

6. Develop model documentation.

7. Perform model analysis

8. Test statistical models

9. Develop life stage components.

10. Interface cost-effectiveness

al gorithms.

11. Coordinate with other entities.

\section{PROJECT STATUS}

Date Initiated: September 1989

SCHEDULE AND MILESTONES

FY 1992: BPA plans to continue funding this contract.

1. Continuing: The contractor will provide reports regarding all objectives.

Results / Conclusions: Work completed

to date: Beta versions of the model for 2. Early 19g0: Complete objectives 1, 2, and 3.

objectives 1,2 , and 3 .

3. Late 1990: Complete objectives 4, 5, and 6.

4. 1991: Complete objectives 7 through 10.

5. Objective 11 is ongoing objective. 
PROJ ECT

NUMBER

91.41

$\frac{\text { TITLE }}{\text { Non-Treaty Storage Compensation }}$
- I daho Power Company

proiect officer: po poe

Praiect officer: pa poe

Obiectives: To rent surplus irrigation water from Idaho water banks and other sources and release it from storage

during spring, summer, and/or fall months to improve anadromous fish passage conditions in the lower Snake River.

$91 \cdot 44$ System Operation Review Various contractors

Proiect officer: D. Johnson

Obiectives: To provide techni. cal assistance to BPA for review and analysis related to system Operation Review.
PROJECT STATUS

Date Initiated: May 1991

Results/Conclusions: None at this time.

Date Initiated: FY 1991

Results/Conclusions: None at this time.
SCHEDULE AND MILESTONES

Fy 1991: Idaho Power Company will rent up to 100,000 acre-feet of water from Water District \#1 and/or from the USBR from Cascade and Deadwood reservoirs at a resonable price subject to BPA concurrence and in a manner minimizing cost to BPA. This is a three-year pilot project.

Fy 1991.92: Initiate individual contracts as required by BPA staff.

$\cdot$


PROJ ECT

NUMBER

91.67

Idaho Water Rental Pil ot Project - Feasibility/Coordination Study - Resident Fish and WildIife - IDFG

Proiect officer: D. Watkins

Objectives:

1. Identify existing resident

fish and wildife resources and programs in the Snake, Payette and $\mathrm{Cl} e a r w a t e r$ rivers. Conduct literature review to determine the habitat conditions for resident fish and wildife in these rivers (e.g. goose nesting below reservoirs, reservoir fisheries, snake River sturgeon populations, river channel capacity, etc.). 2. Identify expected changes in habitat conditions in each river system resulting from various water release

strategies to assist anadromous fish migration.

3. Relate expected changes in habitat conditions to potential i mpacts/benefits to resident fish and wildlife resources and programs.

4. Develop water release strategies that will protect or provide enhancement for resident fish and wildlife resources and programs.

5. Prepare final report.
Expected Start Date: September 1991

Results/Conclusions: None at this time. resident fish and wildlife due to water releases for anadromous fish and recommend the best strategy for benefit to both anadromous fish and resident fish and wildife. Prepare final report.

Fy 1991: Review resident fish and wildlife management plans and develop water release scenarios.

Fy 1992: Determine changes in habitat conditions for 


\section{NEW PROJECTS}

PROJ ECT

NUMBER

$92 \cdot x \times x$

Fish Habitat Technology

Transfer Session

Proiect officer: R. Stoots

Obiectives: Fund and conduct a

technology transfer session

specifically related to columbia

Basin fish and habitat types

for field people responsible

for planning and building BPA

projects. This would include

reporting on research and

findings funded by BPA.

Geographical Information System (GIS) Devel opment

\section{PROJECT STATUS}

New Project

Results/Conclusions: None at this time.
SCHEDULE AND MILESTONES

FY 1992: Conduct technology transfer session.
New Project

Results/Conclusions: None at this time.
FY 1992: Perform needs assessment and implement pilot projects.

\section{Proiect officer: R. Stoots}

\section{Obiectives:}

1. Promote and use GIS within BPA's Fish and Wildlife Division.

2. Develop a GIS database that contains both fish and wildlife projects.

3. Establish and maintain ties with other GIS users as re.

sources for data pertinent to BPA projects. 
PROJ ECT

NUMBER

$92-x X X$

$\stackrel{?}{\overrightarrow{0}}$

$92-x \times x$

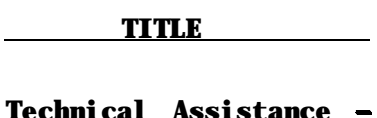

Technical Assistance -

Consultants

Proiect officer: R. Stoots

Obiectives: To supplement the

I i mited staff and time resources

of BPA's Division of Fish and

Wildlife with the services of

expert consultants, who can

provide technical assistance

and training on a wide variety

of issues related to fish and

wildlife habitat.

Public Education - Fish and

WiIdlife Habitat

Proiect officer: S. Levy

Obiectives: Project will

initiate new and/or enhance and

expand existing programs and

materials useful in creating

public awareness and involve.

ment in fish and wildlife

habitat protection and

restoration. The function,

operation, and effectiveness

of programs developed by various

Federal, state, and local

agencies will be monitored,

assessed, and evaluated.

Education programs which are

effective in fish and wildlife

education within the columbia

Basin will be targeted to

increase public participation
New Project

Results/Conclusions: None at this time.

\section{SCHEDULE AND MILESTONES}

Fy 1992: Initiate individual technical assistance contracts as required by BPA staff.

Results/Conclusions: None at this time.

Fy 1992: Education programs initiated. Modification and expansion to be considered. 
PROJ ECT

NUMBER

92-XXX

cont.
TI TLE

in these programs and thereby increase public involvement in

fish and wildlife enhancment

efforts. Where these edu.

cational programs involve youth,

this will also increase the

potential pool of those who may

seek advanced training for

careers in resource management. 
APPENDIX B

ENDANGERED SPECIES ACT PROJECTS

$A=13$ 
1. COMPLETED PROJECTS

PROJ ECT

NUMBER

$90-93$
PROJECT STATUS

Expected Comoletion Date: September 1991

Results/Conclusions: All necessary

samples were collected.

Project officer: G. Bouck

Objectives:

Phase I:

1. Collect $\underline{0}$. nerka for

analysis.

2. Refine DNA analysis.

3. Develop a plan for Phase II. Phase II:

1. Determine best methods of analyzing DNA for b probes.

2. Analyze DNA from $\underline{0}$. nerka

from 12 sources including snake

River, Upper Columbia River, and Frazer River.

3. Compare results for dif. ferences between kokanee and sockeye.

4. Report final results. 
11. FY 1991 ONGOING PROJECTS

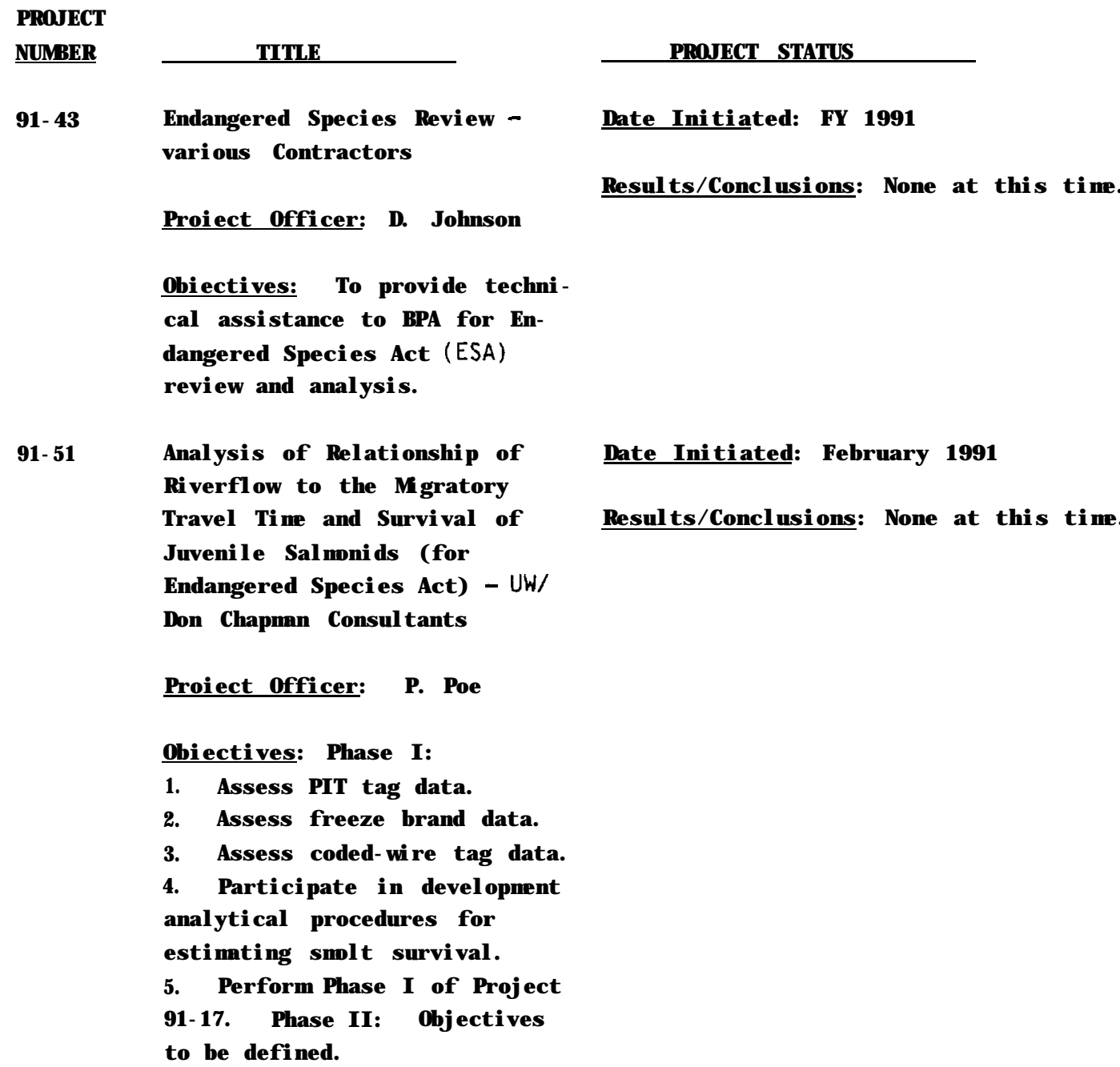

NUMBER

$91 \cdot 43$

various contractors

Proiect officer: D. Johnson

Obiectives: To provide techni

cal assistance to BPA for En.

dangered Species Act (ESA)

review and analysis.

91.51 Analysis of Relationship of

Riverflow to the Migratory

Travel Time and Survival of

Juvenile Salmonids (for

Endangered Species Act) - UW/

Don Chapman Consultants

Proiect officer: P. Poe

Obiectives: Phase I:

1. Assess PIT tag data.

2. Assess freeze brand data.

3. Assess coded-wire tag data.

4. Participate in development

analytical procedures for

estimating $s$ molt survival.

5. Perform Phase I of Project

91.17. Phase II: Objectives

to be defined.

PROJECT STATUS

Date Initiated: FY 1991

Results/Conclusions: None at this time

Date Initiated: February 1991

Results/Conclusions: None at this time.

SCHEDULE AND MILESTONES

Fy 1991.92: Initiate individual contracts as required by BPA staff.

FY 1992: Complete objectives of Phase I and report results. Proceed with Phase II if applicable. 
PROJ ECT NUMBER

$91 \cdot 52$ Genetic consultation Consultant

Proiect officer: G. Bouck

Obiectives: Task order agree.

ment to provide genetic consul.

tation to BPA.

91.64
Little Goo
USACE
Proiect officer: V. Jagendorf
obiectives: This contract funds
the Architect.engineer to pro.
vide the plans, specifications, design analysis, construction and installation of a Passive Integrated Transponder (PIT)
Tag Detector System at the
Little Goose Juvenile Fish Facility. Facilities at Little
Goose Dam would enable conduct
of special juvenile fish
monitoring and research
activities associated with ESA
and increase the capability to
measure the effectiveness of
any Program action.

\section{SCHEDULE AND MILESTONES}

FY 1992: Completion in June 1992.

Fy 1992: Facility is scheduled to be operational by March 21, 1992.

\section{Date Initiated: February 1991}

Results/Conclusions: None at this time.

\section{Results/Conclusions: None at this time.}


PROJ ECT

NUMBER

$91 \cdot 65$

$\frac{P}{\infty}$

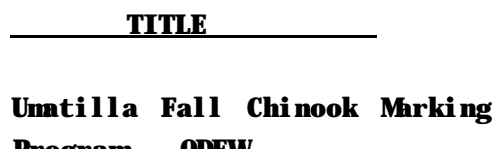

Program - ODFW

Proiect officer: J. Bauer

Objectives:

1. Mark Umatilla salmon for identification so the strays can be removed at Ice Harbor Dam.

2. Evaluate right ventral

fin clip (RV) mortality rate.

3. Evaluate difference between

RV and body tag mortalities.

4. Evaluate differences

between RV and adipose-CWT-RV mortality rates.

91.66

Ice Harbor/Lower Granite Fish

Trapping I mprovements

Proiect officer: J. Marcotte

Objectives: Eval uate current trapping operations and physical facilities for trapping.

Determine operational adjust . ments and/or physical improve. ments that would allow for capture and identification of all salmon. Non-Snake River fish would be prevented from passing these facilities. Operational adjustments would be implemented as soon as feasible.

\section{PROJECT STATUS}

Date Initiated: April 1991

Results/Conclusions: Fin-clipped and tagged $3.4 \mathrm{M}$ fall chinook (ChF).

\section{Expected Start Date: June 1991} Results/Conclusions: None at this time. 2. Fy 1992: Preliminary and final design.

3. FY 1993: Construction.
2. FY 1992: Fin clip and tag, 6.0 M ChF Fin clip and tag, 1,4 M summer chinook (ChS).

3. FY 1993: Fin clip and tag, 7.0 M ChF. Fin clip and tag, 1.4 M ChS.
1. FY 1991: Fin clip and tag, 3.4 M ChF. 
APPENDIX C

LETTERS OF COMMENT ON THE

DRAFT FY 1992 AIWP

AND BPA RESPONSES TO ISSUES RAISED

A. 19 

IAMEr A. GOLLER
CHAIRMAN Idaho

Robert (Bob) Saxvik
Idaho

John C. Brenden Montana

Stan G race Montana
NORTH.. EST POWER PLANNING .OUNCIL

851 S.W. SIXTH AVENUE. SUITE 1100

PORTLAND, OREGON 97204-1348 . (503) 222-5161

Toll free number for Idaho, Montana \& Washington: I-800-222-3355

Toll free number for Oregon: 1-800-452-2324

July 5, 1991

John Palensky

Bonneville Power Administration - PJ

P.O. Box 3621

Portland, Oregon 97208

Dear John:

I appreciate your staff taking time to meet with Council staff to discuss the continuation of habitat work under the Council's existing fish and wildlife program. This letter will clarify and confirm our understanding on the continued implementation of habitat improvement, passage restoration and related projects provided for in Section 703 (c) (1) and Five-Year Action Item 4.2. It is expected that an 'integrated system plan will' be approved' in late $\begin{array}{llllll}1 & 9 & 9 & 2 & \text { and will be used as guidance for implementing future habitat and }\end{array}$ tributary passage projects.

Recently, some of the agency and tribal entities have been asking for guidance on how to proceed in FY 1992 with what they consider to be high priority projects. In addition, some agencies and tribes anticipating a termination of habitat work in the interim (FY 1992) have submitted projects as Priority Salmon Habitat and Production Proposals for early implementation.

We believe that it is important to provide some continuity and stability in the existing habitat work until the fish and wildlife program is amended and the need for and scope of future habitat projects are defined.

At our meeting, we agreed that neither Bonneville nor the Council wanted to see important habitat and passage work stop until an integrated system plan was adopted. Such an action could be very disruptive and cause the agencies and tribes to stop work and terminate or reassign elements of a trained work force. In addition, relationships with private land owners could be damaged if planned and agreed to work was not done on schedule. Termination of some ongoing work could also be inconsistent with the recent request by the Council for proposals for new high priority habitat and production projects.

It was not the Council's intent to terminate habitat work in the absence of an approved integrated system plan. We believe that action item 4.2 and the draft integrated system plan should provide guidance to Bonneville and the agencies and tribes in continuing habitat and tributary passage projects until the program is amended. Also, we do not believe that there is any 
problem with Bonneville's continued funding of needed monitoring and evaluation projects, operating and maintenance of completed projects, or the continued funding of projects such as the Umatilla River Basin trap and haul project $(88-22)$.

A review of the draft FY 1992 Annual Implementation Work Plan and contact with some agency and tribal entities revealed that there is habitat work, other than operation and maintenance, that is not scheduled to to be funded in FY 1992 that should be included. The problems seem to be primarily confined to the John Day Subbasin (Project 84-4 and 84-21), Deschutes Subbasin (Project 81-108) and Project 84-11.

On June 21, at a meeting attended by representatives of Bonneville, the Authority, U.S. Forest Service and the Council, a list of project contracts with a potential for ongoing work was developed. This list was subsequently further refined and confirmed by Wally Steucke with additional contacts with the relevant tribes and agencies (see attachment 1 ).

We recommend that Bonneville request work statements for those projects listed in the attachment and fund those that meet the standards and criteria for implementation that Bonneville has been applying in recent years. At the meeting, it was also discussed that a source of funding for additional projects could come from Project 91-10 (\$1.5 million) in FY 1992. We also believe that this is an appropriate source of funds.

We appreciate your cooperation and assistance in resolving this problem. Please call if we can be of assistance.

Sincerely,

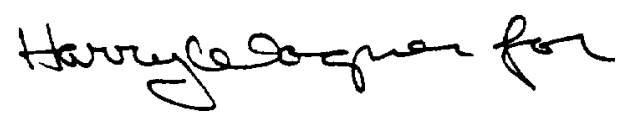

Rick Applegate

Director

Fish \& Wildlife Division

cc: Jeff Gislason -

Gordon Haugen

Wally Steucke

Harry Wagner

I:hw/har.bez.palenuky/habital 
USFS

Clackamas River

86-079

USFS

Oak Grove Creek

81-108

CTWSR

Fifteenmile Crk

$\$ 90$

Beaver Creek

Mia Creek

Shitike Creek

$84-008$

USFS

John Day

Wall Creek

Camas Creek

$84-021$

ODFW

John Day

USFS

Malheur

$87-100$

USFS

Umatilla

$\$ 134$

87-009

USFS

John Day

$\$ 43$

84-025

ODFW

Grande Ronde

1.Source: Wally Stuecke, June 27, 1991

2. Thousands of dollars 
Mr. Rick Applegate, Director

Northwest Power Planning Council

Fish and Wildlife Division

851 SW. Sixth Avenue, Suite 1100

Portland, OR 97204-1348

Dear Mr. Applegate:

In response to your letter dated July 5, 1991, you requested the Bonneville Power Administration (BPA) continue funding specific "ongoing" Fish Habitat Restoration/Passage Projects into FY 92, until the Northwest Power Planning Council (Council) amends their Columbia Basin Fish and Wildlife Program (Program) to guide such projects in FY 93. As a "stop-gap" measure in FY 92, we agree to fund continued implementation for those projects outlined in the enclosed list.

You will note a few differences between the enclosed list and the list provided with your letter of July 5. The major difference is the deletion of project number 81-108, Confederated Tribes of the Warm Springs Reservation. BPA implementation of this project was completed in FY 89. Maintenance, and monitoring and evaluation continue to be funded by BPA. Given that the project has not had implementation activities since 1989, we believe additional project implementation should not occur until the Council's adoption of an Integrated System Plan (TSP).

BPA's FY 92 Annual Implementation Work Plan (AIWP) will be updated to include these projects, with supporting information being requested from project sponsors. The source of funding will be project number 91-10, ISP Implementation, as suggested in your letter. Work statements to be used in final negotiation of specific projects and budgets will not be requested until adoption of the AIWP. 
We plan on discussing this at the next Policy Review Group meeting, and look forward to your participation in that discussion. Should you have questions or concerns, please contact myself or Rick Stoots at 230-5732.

\title{
Sincerely,
}

\section{(Sgd) GREG E. DRAIS}

\author{
Greg Drais \\ Deputy Director, Division of \\ Fish and Wildlife
}

Enclosure

\section{cc:}

Mr. Wally Steucke, Columbia Basin Fish and Wildlife Authority

Mr. Harry Wagner, Northwest Power Planning Council

Mr. Gordon Haugen, U.S. Forest Service 


\begin{tabular}{|c|c|c|}
\hline Project Number & Contractor & Title \\
\hline $84-11$ & $\begin{array}{l}\text { USES } \\
\text { Mt. Hood NF }\end{array}$ & $\begin{array}{l}\text { Clackamas River } \\
\text { Hood River } \\
\text { Fifteenmile Creek }\end{array}$ \\
\hline $84-8$ & $\begin{array}{l}\text { USFS } \\
\text { Umatilla NF }\end{array}$ & $\begin{array}{l}\text { John Day } \\
\text { Wall Creek } \\
\text { Camas Creek }\end{array}$ \\
\hline $84-21$ & ODFW & $\begin{array}{l}\text { John Day } \\
\text { Middle Fork }\end{array}$ \\
\hline $84-22$ & $\begin{array}{l}\text { USFS } \\
\text { Malheur NF }\end{array}$ & $\begin{array}{l}\text { Middle Fork } \\
\text { John Day }\end{array}$ \\
\hline $87-100$ & $\begin{array}{l}\text { USFS } \\
\text { Umatilla NF }\end{array}$ & Umatilla \\
\hline $87-100-2$ & ODFW & Umatilla \\
\hline $84-9$ & $\begin{array}{l}\text { USFS } \\
\text { Wallowa-Whitman NF }\end{array}$ & $\begin{array}{l}\text { John Day and } \\
\text { Grande Ronde }\end{array}$ \\
\hline $84-25$ & ODFW & Grande Ronde \\
\hline
\end{tabular}

(9538W) 


\section{ADDENDUM}

\section{EARLY IMPLEMENTATION PACKAGE}

On August 14, 1991, the Council amended a number of high priority salmon recovery actions into the Program as part of an Early Implementation Package (EIP). BPA plans to implement, as soon as possible, those EIP projects for which it is responsible and to use, to the extent practicable, the IPP to plan implementation. To define the projects to a degree that will allow BPA procurement, BPA may need to consult with the Council and project sponsors and request assistance from the appropriate IPP Scoping Groups. The projects for which the Council designated BPA as a responsible agency are listed in the following table:

\section{PRIORITY SALMON HABITAT PRODUCTION PROPOSALS}

\section{Project Description with Council's Time Frame}

Diversion Screening and Passage

(Committees by 10/1/91, Agency Priority

List by $12 / 15 / 91$, Final Plan by $2 / 1 / 92$,

with implementation beginning in 1992,

and finishing in 1995)

Passage at Starbuck Dam

(Planning and implementation to begin

as soon as possible)

Snake River Sockeye

(Continued implementation of ongoing

Sockeye Program with IDFG, ShoBan

Tribe, and UI

Grande Ronde Spring Chinook (Trapping)

(Planning and implementation to begin

as soon as possible)

Portable Trapping Facilities

(Planning and implementation to begin

as soon as possible)

Hatchery Guidelines/Wild Stock Protection

(Report to Council by 12/31/91)

Marking Hatchery Salmon

(Agencies and Tribes identify priority hatcheries by $12 / 31 / 91$, Feasibility report to Council

by $2 / 1 / 92$ )

\section{Responsible Agency}

BPA, NMFS, Others

BPA, ODFW

BPA, IDFG, ShoBan Tribe, UI

BPA, ODFW

BPA, Various Agencies

BPA, Various Agencies

BPA, Various Agencies 


\section{Proiect Description with Council's Time Frame}

Ringold Hatchery Water Acquisition

(Planning and implementation to begin

as soon as possible)

Snake River Fall Chinook Genetics/Status

(Planning and implementation to begin as soon as possible, Agencies and Tribes Rehabilitation Actions Report to Council by $10 / 10 / 91$ )

Model Watershed Studies

(Report to Council by $2 / 1 / 92$, with

implementation to begin in 1992)

Fall Chinook Life History

(Planning and implementation to begin

as soon as possible)

PIT Tag Detectors

(Planning and implementation to begin

as soon as possible)

\section{Responsible $\mathrm{C} \quad \mathrm{V}$}

$\mathrm{BPA}, \mathrm{WDF} \underline{1 /}$

$\mathrm{BPA}$ and Others

BPA and State Agencies

BPA， USFWS

$\mathrm{BPA}, \mathrm{COE}$

1/ BPA may not be an appropriate funding agency for the Ringold Hatchery Water Acquistion project.

$9989 W: 8 / 27 / 91$ 